\title{
Evolutionary prospection in the Neogene planktic foraminifer Globorotalia menardii and related forms from ODP Hole 925B (Ceara Rise, western tropical Atlantic): evidence for gradual evolution superimposed by long distance dispersal?
}

\author{
Michael Knappertsbusch ${ }^{1}$ D
}

Received: 3 September 2014/Accepted: 17 February 2016/Published online: 24 March 2016

(c) The Author(s) 2016. This article is published with open access at Springerlink.com

\begin{abstract}
Evolutionary prospection is the study of morphological evolution and speciation in calcareous plankton from selected time-slices and key sites in the world oceans. In this context, the Neogene menardiform globorotalids serve as study objects for morphological speciation in planktic foraminifera. A downcore investigation of test morphology of the lineage of G. menardii-limbata-multicamerata during the past 8 million years was carried out in the western tropical Atlantic ODP Hole 925B. A total of 4669 specimens were measured and analyzed from 38 stratigraphic levels and compared to previous studies from DSDP Sites 502 and 503. Collection of digital images and morphometric measurements from digitized outlines were achieved using a microfossil orientation and imaging robot called AMOR and software, which was especially developed for this purpose. Most attention was given to the evolution of spiral height versus axial length of tests in keel view, but other parameters were investigated as well. The variability of morphological parameters in $G$. menardii, G. limbata, and G. multicamerata through time are visualized by volume density diagrams. At Hole 925B results show gradual test size increase in G. menardii until about 3.2 Ma. The combination of taxonomic determination in the light microscope with morphometric investigations shows strong morphological overlap and evolutionary continuity from ancestral to extant $G$.
\end{abstract}

Electronic supplementary material The online version of this article (doi:10.1007/s13358-016-0113-6) contains supplementary material, which is available to authorized users.

Michael Knappertsbusch

michael.knappertsbusch@unibas.ch

1 Natural History Museum Basel, Augustinergasse 2, 4001 Basel, Switzerland menardii (4-6 chambers in the final whorl) to the descendent but extinct $G$. limbata (seven chambers in the final whorl) and to $G$. multicamerata ( $\geq 8$ chambers in the final whorl). In the morphospace defined by spiral height $(\delta X)$ and axial length $(\delta Y)$ Globorotalia limbata and $G$. multicamerata strongly overlap with $G$. menardii. Distinction of G. limbata from G. menardii is only possible by slight differences in the number of chambers of the final whorl, nuances in spiral convexity, upper keel angles, radii of osculating circles, or by differences in reflectance of their tests. Globorotalia multicamerata can be distinguished from the other two forms by more than eight chambers in the final whorl. It appeared as two stratigraphically separate clusters during the Pliocene. Between 2.88 and $2.3 \mathrm{Ma}$ G. menardii was severely restricted in size and abundance. Thereafter, it showed a rapid and prominent expansion of the upper test size extremes between 2.3 and 1.95 Ma persisting until present. The sizefrequency distributions at Hole 925B are surprisingly similar to trends of menardiform globorotalids from Caribbean DSDP Site 502. There, the observations were explained as an adaptation to changes in the upper water column due to the emergence of the Isthmus of Panama. In light of more recent paleontological and geological investigations about the completion of the permanent land connection between North and South America since about 3 Ma the present study gives reason to suspect the sudden test size increase of $G$. menardii to reflect immigration of extra-large G. menardii from the Indian Ocean or the Pacific. It is hypothesized that during the Late Pliocene dispersal of large G. menardii into the southern to tropical Atlantic occurred during an intermittent episode of intense Agulhas Current leakage around the Cape of Good Hope and from there via warm eddy transport to the tropical Atlantic (Agulhas dispersal hypothesis). 
Keywords Evolution - Globorotalia menardii . Morphometry $\cdot$ Neogene $\cdot$ Atlantic Ocean

\section{Introduction}

The discovery and documentation of speciation patterns and geography of fossil species remain a recurrent task to paleobiologists, morphometrically oriented taxonomists and stratigraphers. In case of extant organisms and on ground of the biospecies concept, which sees a species as a reproductive community, morphological classification and character matrix analysis are tools to delimit boundaries between species among a multitude of other methods including geochemistry, biogeography, and behavioral or physiological observations. During the past decade, molecular taxonomy has become indispensable to unravel evolution, especially when genetic analyses of extant representatives of an evolutionary lineage are combined with morphological observations. This applies also to micropaleontology, where molecular clocks were calibrated using existing phylogenetical schemes that were earlier derived from biostratigraphic range charts and/or morphological considerations (de Vargas et al. 1997; Darling et al. 1999; de Vargas et al. 2001). In the case of planktonic foraminifera, where such combined evidence becomes increasingly available, many paleontologically derived phylogenetic schemes remain based on visual interpretations and on the succession of similar species in stratigraphic range charts. Unfortunately, there is only limited effort to quantify morphological transitions between succeeding species within a lineage. Reconstruction of phylogenetic relationships requires the detection of speciation modes, their time interval and a geographic mapping of such patterns. For the documentation of morphological changes within a suspected lineage high quality records are a prerequisite. Microfossils offer the unique possibility to track back morphological test variations over very long time spans and in great detail, provided that abundance and preservation of hardparts, and stratigraphic resolution are good enough, and that the sediments were deposited without interruption. Such analyses are ideally done using easily identifiable species, that can be accurately be described by morphometry across its full stratigraphic, biogeographic and ecological ranges.

Foraminifera are known for morphological convergence trends (Bolli 1986; examples given in McGowran 2005); iterative evolution (Cifelli 1969; Banner 1982; Chapman 2000) and polypheny (Darling et al. 1997; Langer 1999), all of which make the interpretation of patterns of morphological evolution in this group of microfossils interesting, but difficult. Particularly challenging in foraminiferal taxonomy, biostratigraphy and phylogeny are cryptic species, where the specific status cannot be estimated from morphology alone. Instead, such cryptic species show relevant nuances in their genetic makeup or geochemical composition of foraminiferal tests (Norris et al. 1996; Huber et al. 1997; Darling et al. 1999, 2004; Kucera and Darling 2002; Weiner et al. 2015). Sometimes the reverse applies as well, as for example in the planktonic foraminifer Globigerinoides sacculifer. In this case, genetical differentiation is lacking, but test morphology of the plexus is highly diverse (André et al. 2013). The growing evidence of cryptic planktic foraminiferal species does in principle not contradict earlier evolutionary models: It even confers permanent speciation in the sea, where populations remain morphologically similar during the early phase of speciation. Only when populations survive over long enough time the diverging descendent population will accumulate and eventually may later be recognized macroscopically by morphological differences. This has direct consequences for biostratigraphers because reported first appearance datums in the sedimentary archives must be seen as minimum ages for true evolutionary events (see for example Fig. 2 in Strotz and Allen 2013).

The recognition of cryptic species in foraminifera requires detailed knowledge about subtle variation of their tests, ultrastructural studies or ontogenetic observations on specific and subspecific level. Species definitions, classification schemes, phylogenetic reconstructions and development of species concepts remain therefore still challenging to taxonomers. There is a need to include into the species definitions not only the global biogeography of morphological variability proving interconnection of phenotypic homogeneity, but also reconnaissance of speciation intervals and evolutionary continuity (Hohenegger 2014). This author amalgamated four basic theorems "shape homogeneity", "ontogenetic cohesion", "homogeneous ecological niches" and "evolutionary continuity" into a theoretical basis and so has combined the many biological and paleontological aspects for species delimitation towards a more general species concept. It follows, that first and last appearance datums (FADs and LADs, respectively), appearance and disappearance loci, and ancestor-descendent relationships are all necessary ingredients for species definitions. Each of them is of equal importance to the traditional morphological classifiers. It is, therefore, important to identify and map in the geological record the patterns of speciation modi like cladogenesis (=splitting of an ancestral lineage into its descendent forms) or anagenesis (=one-to-one ancestor to descendent relationship). According to Strotz and Allen (2013), the anagenetic mode of evolution can be recognized if the FAD of the descendant coincides with the LAD of the ancestor. 
In cladogenetic mode, the FAD of the descendant still precedes the LAD of the ancestor.

In cladogenesis demonstration of empty morphospace between diverging branches is an important criterion to infer speciation (Aze 2011; Aze et al. 2011). In the author's opinion all these criteria must be considered, and ideally one would like to empirically demonstrate the existence of ancestor-descendant transitions by morphometric measurements if possible.

In the past and up to present, typological species concepts of foraminifera prevailed, at least in paleontology. Frequently they originated from the 1950 s to 1970 s petroleum industry for quick age dating of sediments (McGowran 2005), and thereby grossly neglected the complex variability on inter- and intraspecific level (Scott 2011). In the meantime, the scientific community is becoming aware of this deficiency and currently about 30 different species concepts have been proposed (Mallet 2007; Hohenegger 2014). In the case of planktic foraminifera there is an ongoing effort by various experts to stabilize taxonomic concepts (see the resources and various working groups on Mesozoic and Paleogene planktonic foraminifera on the Chronos portal), but more comparison of classical morphologically based taxonomy with phylogenetic species concepts is required (Young et al. 2014).

Planktic foraminifera are interesting fossils, because of their abundance in deep-sea sediments and excellent power in stratigraphy. They gave rise to classical morphometric studies towards both, taxonomic concepts and improvement of evolutionary theory. Examples include but are not limited to those of Malmgren et al. (1983), Malmgren and Kennett (1983), Berggren and Lohmann (1984), Cifelli and Scott (1986), Lazarus et al. (1995), Norris et al. (1996), Spencer-Cervato and Thierstein (1997) and Pearson and Ezard (2014). Some of these studies were motivated by proving or falsifying the punctuated equilibrium model of Eldredge and Gould (1972) but were often based on limited geographic coverage disregarding the global biogeography of morphological test variability. Only with time the focus broadened to carry out more global investigations and researchers so began to grasp the full morpho-geographic potential of a species' variability (Healy-Williams and Williams 1981; Hills 1988; Knappertsbusch 1990, 2000; Lazarus et al. 1995; Kucera and Malmgren 1996; Bollmann 1997; Schmidt 2002; Schmidt et al. 2004).

Many of the morphological ancestor-descendent transitions and phylogenetical schemes arose for the refinement of planktic foraminiferal biostratigraphic zonal schemes, and they are still in use. Prominent of these is the phylogenetic atlas of Neogene planktic foraminifera from Kennett and Srinivasan (1983). Unfortunately, the transitions in most schemes are poorly referenced with quantitative empirical evidence and also more recent phylogenies of
Cenozoic planktic foraminifera (Aze et al. 2011) need further improvement on this aspect.

\section{Strategy of evolutionary prospection}

Reproductive isolation is the processes behind speciation by stopping the gene flow. The form of isolation (allopatry or geographical separation, sympatry, reproductive parapatry, bathymetric separation), by which interruption of gene flow is achieved, may vary. This is also reflected in the distribution of morphotypes in the underlying sediments. In this context it is relevant to separate adaptation from ecophenotypic plasticity, the latter being an important reagent for the former. Recognition of the dynamics and biogeography of speciation, regardless of whether the mode is cladogenetic or anagenetic, requires inclusion of several key locations with known environmental conditions. Biogeographic mapping at key sites and time slices is therefore compulsory in such an investigation. Implicitly it is assumed here, that morphological ecophenotypy follows environmental gradients, and that the species' adaptations to changing environments are known. In addition, reproductive isolation and the formation of morphotypes associated with it needs to be maintained over sufficiently long time to be detectable in the geological record. For any investigation to be carried out this means that an extended stratigraphic range is taken into consideration.

Complications arise if isolation of plankton populations occurs vertically, as in planktic organisms (Schweitzer and Lohmann 1991; Chaisson 2003; Ishitani et al. 2014). Morphotypes from diverging populations, that inhabited different water depths, become then mixed up in the underlying sediments. This situation mimics sympatric speciation, where ancestral and descendent populations coexist in the same habitat (Lazarus 1983), and where other than only geographic isolation mechanisms may operate (see Dobzhansky (1970), and Coyne and Orr (1989) for descriptions of different mechanisms of reproductive isolation). The morphologically oriented paleontologist is then often faced with the difficulty to disentangle overlapping morphotypes that originally inhabited different water depths, but show only subtle test variations. The prerequisite that morphology varies as a result of changes in any of the considered factors remains and usually cannot be avoided in paleontology. The situation becomes even more complicated if closely related species within the same biogeographic area develop convergent trends in test morphology. Considering a single time slice either analyses of stable isotopes, $\mathrm{Mg} / \mathrm{Ca}$ ratios and other paleotemperature proxies, or geographic mapping of test variation in environmental end-members may then help out to deconvolve the fossil assemblages into the original plankton populations. If reproductive isolation continues over a longer time 
span, adaptation progresses lead to morphological divergence, and this can be easier observed.

In the opinion of the author, these difficulties can best be resolved by mapping morphological variation of foraminiferal tests in a spatio-temporal grid consisting of several sites and time slices. The expectation is that a global picture about the evolution of foraminiferal test morphology will emerge, and that time intervals and loci of speciation events will be recognized by this approach. This strategy was called evolutionary prospection in Knappertsbusch (2011) and was followed in previous exploratory studies about the Neogene foraminiferal group of Globorotalia menardii and related groups. The first of these studies was by Knappertsbusch (2007) at two DSDP sites on either side of the Isthmus of Panama over a period of the past 8 Myrs. In a subsequent global survey Brown (2007) addressed the purely geographic aspect of test variation of modern Globorotalia menardii and related forms in Holocene sediments. In a follow-up study, the biogeography of menardiform test variation was explored during a mid-Pliocene time slice (Mary 2013; Mary and Knappertsbusch 2013, 2015).

\section{Selection of species}

Evolutionary prospection requires suitable taxa for mapping and testing phylogenetic models. Cenozoic planktic foraminifers are ideal for this purpose because of their global distribution, high abundance, and excellent stratigraphic age control, but also because of occupation and adaptation to new niches emerging in the course of the Cenozoic planetary cooling and due to formation or disappearance of oceanic gateways (Zachos et al. 2001; Schmidt 2002; Schmidt et al. 2004). Other preconditions, such as a strong diversification within a stratigraphically comparably long-lasting lineage, strong resistance to carbonate dissolution, extant representatives, and a not too difficult morphology for orientation and measurement of tests, are all met in the morphological plexus of Globorotalia menardii-limbata-multicamerata (1-15 on Fig. 18). This group is therefore used as the prime study target in the present investigation.

\section{Questions to be addressed by the present study}

In order to put to test the before-mentioned prospective work of Knappertsbusch (2007) about the morphological evolution of the Globorotalia menardii-G. limbata-G. multicamerata lineage the present study investigates the long-term variability of these forms in an area outside the influence of the closure history of Isthmus of Panama paleoceanography. The tropical West Atlantic ODP Hole 925B on Ceara Rise (Fig. 1) was chosen because it is outside Caribbean oceanographic influence. It has excellent carbonate preservation, and numerous detailed paleoceanographic research results exist from that site (Curry et al. 1995). The North Brazil Current, where Site 925 is situated, flows northwest and joins the Caribbean Current. If there were an Atlantic-Caribbean teleconnection, then it should be from the Atlantic into the Caribbean, but not reverse, which makes the Caribbean Sea a biodiversity trap like many marginal seas.

In the tropical West Atlantic the August sea-surface temperature anomaly between the Last Glacial Maximum (LGM, Late Pleistocene) and the Holocene nearly completely disappears or is small (compare reconstructions from CLIMAP project members in McIntyre and Cline 1981; Braconnot et al. 2012). Recent climate models showed, that over longer time spans such as during the Eemian and the mid-Pliocene, temperature deviations from the modern warm climate were also small to minimal in that area (Lunt et al. 2010; Hill et al. 2012; Haywood et al. 2013). This stability over time makes Site 925 interesting for looking at the course of evolution in seeming absence of selection by external physical forcing or climatic changes.

It is particularly exciting to investigate the reasons for the prominent increase in test size of G. menardii recognized between 2.58 and $1.7 \mathrm{Ma}$ and its near synchronicity in the Caribbean Sea, as well as the preceding divergence of G. limbata and G. multicamerata from the G. menardii stock.

By measuring the test size and simple shape changes through time using traditional morphometric techniques these questions are addressed at Hole 925B for the past 8 million years. Comparisons are made to the previous investigation in the Caribbean Sea and eastern equatorial Pacific DSDP Sites 502 and 503 of Knappertsbusch (2007).

\section{Materials and methods}

\section{Core location, stratigraphy, and sampling}

ODP Site 925 is the bathymetrically shallowest of a series of cores raised from Ceara Rise during ODP Leg 154. Hole $925 \mathrm{~B}\left(4^{\circ} 12^{\prime} \mathrm{N}, 43^{\circ} 29^{\prime} \mathrm{W}, 3041 \mathrm{~m}\right.$ water depth, Fig. 1) has a nearly $100 \%$ recovery from the Pleistocene through the middle Miocene. This interval is largely unaffected by selective carbonate dissolution. It has an integrated biostratigraphic record based on planktic foraminifera, calcareous nannofossils and stable oxygen isotopes (Curry et al. 1995; Chaisson and Pearson 1997; Bickert et al. 1997).

For the present investigation 38 samples were selected from Hole 925B covering the past 8 million years (Fig. 2a). 
Fig. 1 Geographic positions of ODP Hole 925B investigated during the present study and of DSDP Sites 502 and 503 mentioned in the text. Dotted, hatched, and shaded areas indicate relative $(\%)$ abundances of $G$. menardii in sediment core tops after Bé (1977). Dashed lines with arrows represent most relevant surface ocean currents $(A C$ Agulhas Current and Agulhas Retroflection, ARs Agulhas warm core rings, $B C$ Benguela Current, SEC South Equatorial Current, BRC Brazil Current, SAC South Atlantic Current, $S E C C$ Southern Equatorial Counter Current, $N B C$ North Brazil Current, NEC North Equatorial Current, $N E C C$ North Equatorial Counter Current, $C C$ Caribbean Current, FC Florida Current, GS Gulf Stream). Currents in partem after Wefer et al. (1998), map with frequencies of $G$. menardii taken from Fig. 4 in Broecker and Pena (2014)

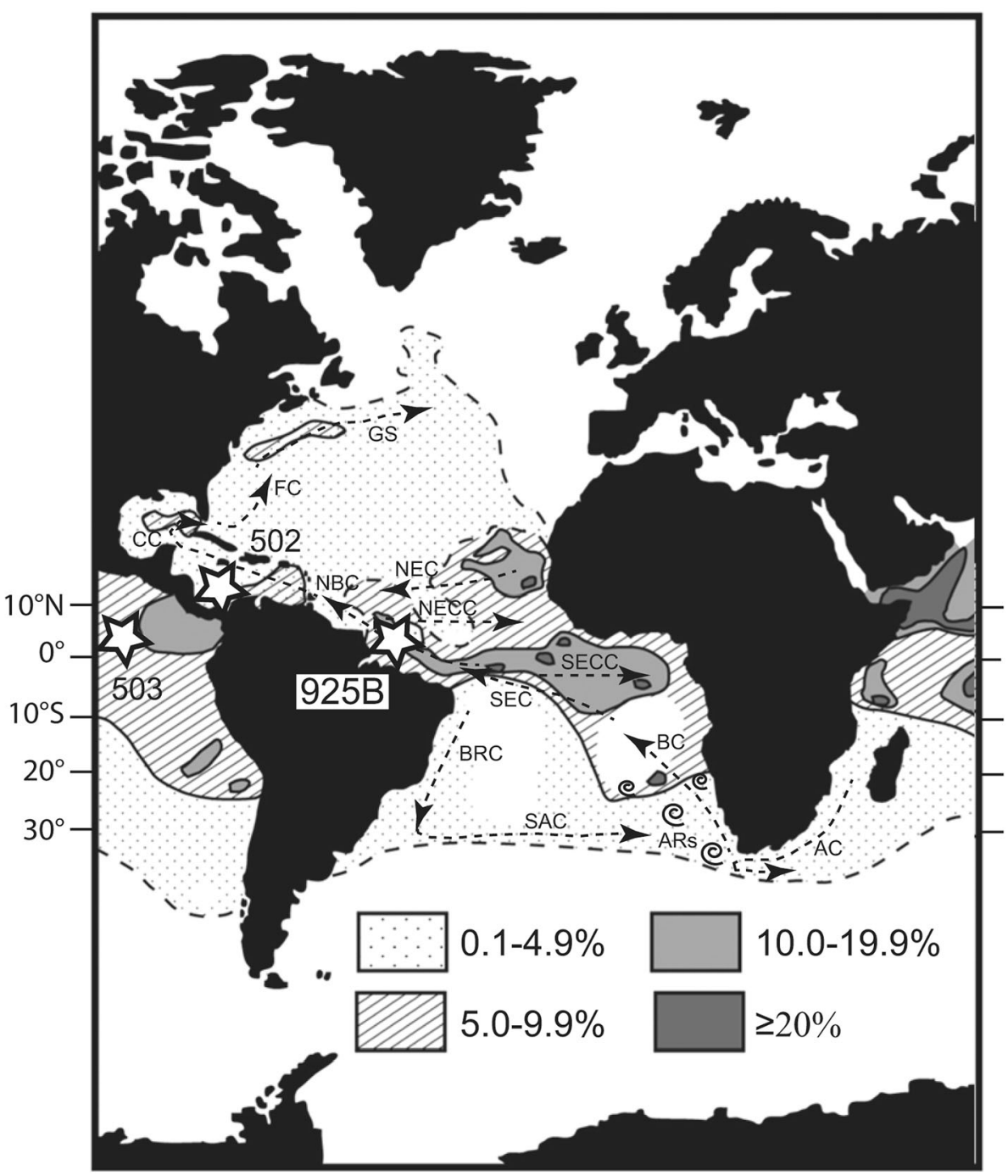

Samples were taken at similar ages as previously investigated at DSDP Sites 502 (Caribbean Sea) and 503 (eastern equatorial Pacific) in Knappertsbusch (2007). For the calculation of the respective core depths the benthic foraminiferal oxygen- and carbon isotope record illustrated in Fig. 4 of Bickert et al. (1997) from Site 925 was applied (see Table 1; Fig. 2b for sample depths and numerical age model). Conversion of composite depths (mcd) to mbsf was accomplished using the information given in the respective chapters of the Initial and Scientific Reports to ODP Leg 154. For comparison of the age model from ODP Site 925 with those from DSDP Sites 502 and 503 and for interpolation of model points to core depths the Age Depth Plot and Age Maker programs described in Lazarus (1992) were used. To refine the stratigraphic resolution in the upper part of Hole 925B additional samples were taken preferentially within interglacials (i.e., events 1.1 through 11.3 mentioned in Table 1). Because of frequent absence of G. menardii during glacials (Ericson and Wollin 1956a, b,
1968, Da Costa Portilho-Ramos et al. 2014) glacial periods were not taken into consideration for this purpose. The time span between 3.2 and 3.25 Ma was sampled from ODP Hole $925 \mathrm{~B}$ at 3.2 Ma and in one extra sample from nearby ODP Hole $926 \mathrm{~A}$ at $3.25 \mathrm{Ma}$ because the variability of menardiform tests was investigated on a global scale from this paleoclimatically interesting Pliocene interval by Mary (2013), Mary and Knappertsbusch (2013, 2015). In the diagrams illustrated in the following sections, measurements from these two samples were combined and plotted at 3.23 Ma (average age of 3.225 Ma rounded to 3.23 Ma).

The sample ages given in Table 1 were linearly interpolated from a numerical age model provided by Bickert et al. (1997). The data of this model are supplied in the supplementary electronic materials (file AgeModel_925B.txt as obtained from Torsten Bickert after personal correspondence during 23 September 2007). This age model relies on microfossil datums and core depths given in Curry et al. (1995) for Site 925. The microfossil datums 


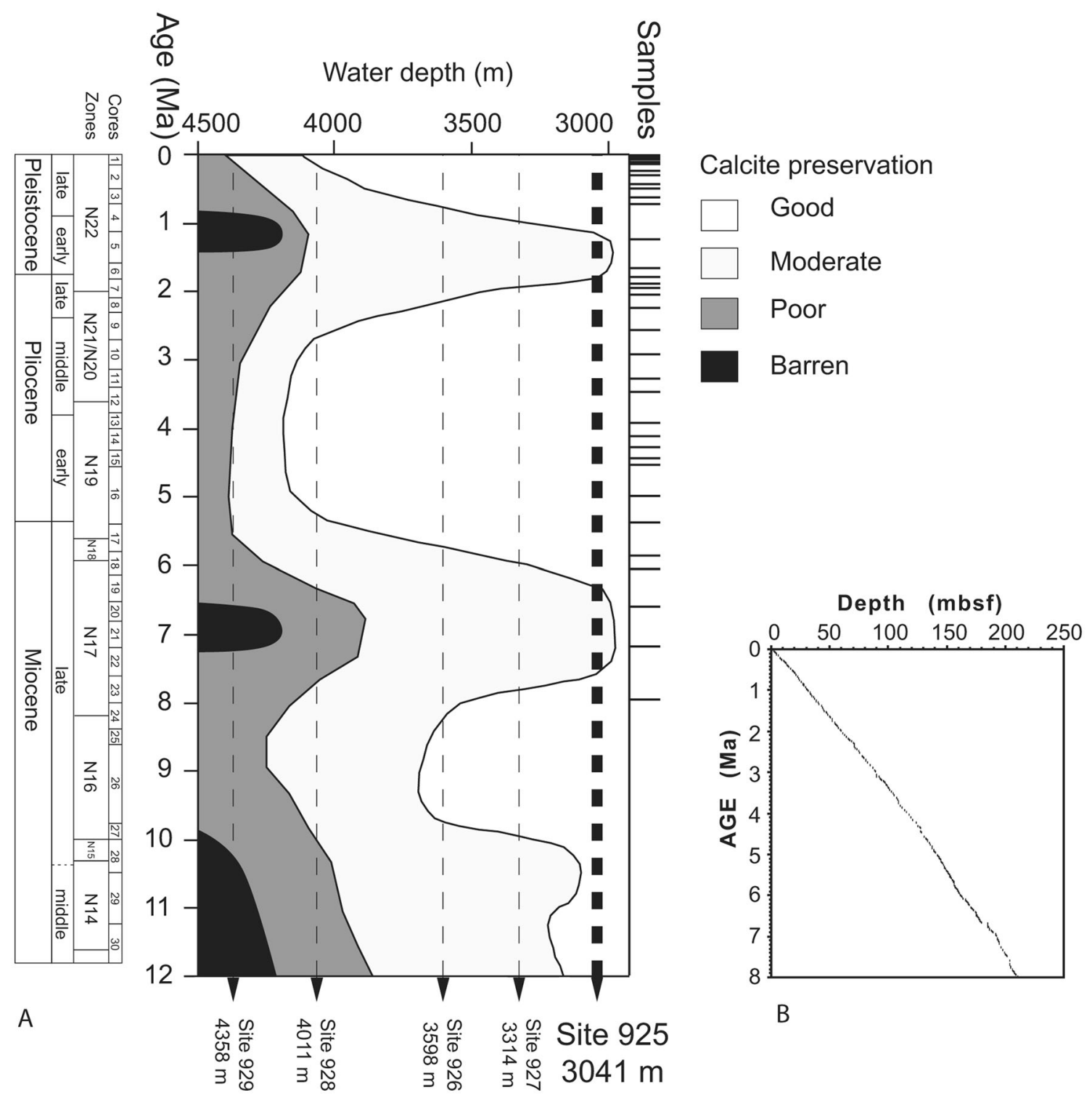

Fig. 2 a Stratigraphic position of samples studied at ODP Site 925. The thick dashed vertical line indicates the waterdepth of Site 925, thin gray dashed vertical lines indicate water depths of the remaining sites during ODP Leg 154. The shaded areas (i.e., black, dark gray, light gray, and white) represent calcite preservation (i.e., barren, poor, moderate, and good) on Ceara Rise and were taken from Fig. 6 in Chaisson and Pearson (1997). It shows, that carbonate oozes at Site

used follow the integrated chronology of Berggren et al. (1995), which was adopted for the present investigation. Preference to that time-scale over more recent chronologies was taken to facilitate direct comparison of morphological trends of G. menardii from ODP Site 925 with those from DSDP Sites 502 and 503 in Knappertsbusch (2007), where the chronology of Berggren et al. (1995) was also applied. The $\delta^{18} \mathrm{O}$ events indicated in Table 1 were identified using the oxygen isotope record for Cibicides wuellerstorfi published in Bickert et al. (1997). Ages for the Miocene and
925 experienced no or only little calcite dissolution. b Age (in Ma) versus depth (meters below seafloor) plot used for the calculation of numerical sample ages at ODP Hole 925B according to data from Bickert et al. (1997). High-resolution data were provided for this site after personal correspondence with Torsten Bickert from 23 September, 2007, and are supplied as file AgeModel_925B.txt in the electronic supplementary materials

Pliocene epoch- and subepoch boundaries follow the nomenclature of Lourens et al. (2004) (i.e., their Fig. 21.1). According to these authors, the Pliocene/Pleistocene boundary is set at $1.81 \mathrm{Ma}$. The subdivision of the Pleistocene follows the nomenclature of Gibbard and van Kolfschoten (2004), with the boundary of the Early to Middle Pleistocene at the Matuyama-Brunhes magnetic reversal $(0.78 \mathrm{Ma})$ and the boundary of the Middle to Late Pleistocene (Saalian/Eemian) at $126 \mathrm{ka}$. The base of the Holocene is taken at the Last Termination at 11.5 Ma (see 
Table 1 Depths (mbsf, mcd) and ages (Ma) of samples studied

\begin{tabular}{|c|c|c|c|c|}
\hline Sample & Depth (mbsf) & Depth (mcd) & Age (Ma) & $\delta^{18} \mathrm{O}$ event \\
\hline ODP 154-925B-1-1, 0-2 cm & 0.01 & 0.01 & 0.00 & 1.1 \\
\hline ODP 154-925B-1-1, 15-16 cm & 0.16 & $0.16^{\mathrm{a}}$ & 0.003 & 1.1 \\
\hline ODP 154-925B-1-3, 36.5-37.5 cm & 3.36 & $3.36^{\mathrm{a}}$ & 0.081 & 3.3 \\
\hline ODP 154-925B-1-3, 125-126 cm & 4.25 & $4.25^{\mathrm{a}}$ & 0.11 & ca 5.5 \\
\hline ODP 154-925B-2-2, 135-136 cm & 7.36 & $8.06^{\mathrm{a}}$ & 0.202 & 7.1 \\
\hline ODP 154-925B-2-3, 76-77 cm & 8.27 & $8.96-8.97^{\mathrm{a}}$ & 0.225 & 7.3 \\
\hline ODP 154-925B-2-6, 37-38 cm & 12.37 & $13.08^{\mathrm{a}}$ & 0.334 & 9.1 \\
\hline ODP 154-925B-2-CC, 25-26 cm & 14.03 & $15.84^{\mathrm{a}}$ & 0.418 & ca 11.3 \\
\hline ODP 154-925B-3-3, 67.5-68.5 cm & 17.68 & 20.59 & 0.51 & \\
\hline ODP 154-925B-4-1, 17-18 cm & 23.68 & 26.89 & 0.73 & \\
\hline ODP 154-925B-4-3, 74-75 cm & 27.25 & $30.5-31.5^{\mathrm{a}}$ & 0.856 & \\
\hline ODP 154-925B-5-1, 140-141 cm & 34.41 & 38.35 & 1.12 & \\
\hline ODP $154-925 \mathrm{~B}-5-6,85-86 \mathrm{~cm}$ & 41.36 & $45.1-45.5^{\mathrm{a}}$ & 1.344 & \\
\hline ODP 154-925B-6-2, 89-90 cm & 44.9 & 48.56 & 1.47 & \\
\hline ODP 154-925B-6-6, 3-4 cm & 50.04 & $53.6-53.8^{\mathrm{a}}$ & 1.645 & \\
\hline ODP 154-925B-6-CC, $10-11 \mathrm{~cm}$ & 52.19 & 55.85 & 1.735 & \\
\hline ODP $154-925 \mathrm{~B}-7-2,62-63 \mathrm{~cm}$ & 54.13 & 58.47 & 1.8 & \\
\hline ODP 154-925B-7-5, 71.5-72.5 cm & 58.72 & 63.06 & 1.95 & \\
\hline ODP 154-925B-7-CC, $10-11 \mathrm{~cm}$ & 61.68 & 66.02 & 2.057 & \\
\hline ODP $154-925 \mathrm{~B}-8-3,38-39 \mathrm{~cm}$ & 64.89 & $68.8-69.2^{\mathrm{a}}$ & 2.154 & \\
\hline ODP $154-925 B-8-6,13-14 \mathrm{~cm}$ & 69.14 & $73.0-73.5^{\mathrm{a}}$ & 2.266 & \\
\hline ODP $154-925 B-8-6,124-125 \mathrm{~cm}$ & 70.25 & 74.36 & 2.3 & \\
\hline ODP 154-925B-9-5, 92.5-93.5 cm & 77.93 & 83.26 & 2.594 & \\
\hline ODP $154-925 B-10-4,126.5-127.5 \mathrm{~cm}$ & 86.27 & 92.06 & 2.88 & \\
\hline ODP 154-926A-11-2, 20-21 cm & 91.2 & 103.25 & 3.25 & \\
\hline ODP 154-925B-11-4, 66-67 cm & 95.17 & 104.44 & 3.2 & \\
\hline ODP $154-925 \mathrm{~B}-12-1,68-69 \mathrm{~cm}$ & 100.19 & 110.34 & 3.39 & \\
\hline ODP $154-925 B-13-5,127-128 \mathrm{~cm}$ & 116.27 & 128.34 & 3.99 & \\
\hline ODP $154-925 \mathrm{~B}-14-2,51-52 \mathrm{~cm}$ & 120.51 & 132.85 & 4.14 & \\
\hline ODP 154-925B-14-6, 130-131 cm & 127.31 & 139.65 & 4.35 & \\
\hline ODP 154-925B-15-3, 140-141 cm & 132.4 & 145.71 & 4.62 & \\
\hline ODP $154-925 B-15-6,65-66 \mathrm{~cm}$ & 136.15 & 149.46 & 4.77 & \\
\hline ODP $154-925 B-16-3,104-105 \mathrm{~cm}$ & 141.54 & 156.36 & 5 & \\
\hline ODP $154-925 B-16-C C, 15-16 \mathrm{~cm}$ & 147.11 & 161.93 & 5.268 & \\
\hline ODP 154-925B-18-1, 57-58 cm & 157.07 & 173.22 & 5.78 & \\
\hline ODP 154-925B-18-5, 106-107 cm & 163.56 & 180.43 & 6.07 & \\
\hline ODP 154-925B-20-1, 020-021 cm & 175.71 & 193.39 & 6.49 & \\
\hline ODP 154-925B-21-CC, 4-5 cm & 194.93 & 216.22 & 7.195 & \\
\hline ODP $154-925 \mathrm{~B}-23-4,103-117 \mathrm{~cm}$ & 209.64 & 234.15 & 7.96 & \\
\hline
\end{tabular}

The numerical ages from Site 925B follow the astronomically tuned age model of Bickert et al. (1997). The basis for the numerical age determination for sample 926A-11-2, 20-21 cm were the stratigraphic information given in the ODP Leg 154 Shipboard Scientific Party (1995) for Site 926 (Initial Reports, chapter 5, pp. 172, 182-183 and Tables 4 and 7 therein). The last column indicates interglacial warm $\delta^{18} \mathrm{O}$ events, within which additional samples were selected (the $\delta^{18} \mathrm{O}$ event nomenclature follows Table 1 in Farrell et al. 1995)

${ }^{a}$ Samples were selected within peaks of warm interglacial periods following the benthic $\delta^{18} \mathrm{O}$ (Cibicides wuellerstorfi) curve for Site 925 shown in Fig. 4 and Appendix I of Bickert et al. (1997). The necessary composite depth to mbsf conversion was using the respective information given in the site chapters of the Initial Report to Leg 154 (e.g. Table 4 on page $81 \mathrm{ff}$ ). In case of sample 925B-2-CC, 25-26 cm the average offset of $1.805 \mathrm{~m}$ (from $0.7 \mathrm{~m}$ for $2 \mathrm{H}-\mathrm{CC}$ and $2.91 \mathrm{~m}$ for $3 \mathrm{H}-1$ ) was applied 
Fig. 21.4 in Lourens et al. 2004). These ages for epoch and stage boundaries are adopted throughout the present investigation.

\section{Laboratory processing of samples}

Approximately $2-3 \mathrm{~cm}^{3}$ of bulk sediment per sample were dried at $40{ }^{\circ} \mathrm{C}$, weighted, disintegrated in boiling water with soda as an additive, and then wet sieved over a $63 \mu \mathrm{m}$ mesh. The foraminiferal fraction larger than $63 \mu \mathrm{m}$ was oven-dried $\left(40{ }^{\circ} \mathrm{C}\right)$, and weighted again. This fraction was used for morphometric measurements of menardiform globorotalids. The fraction smaller than $63 \mu \mathrm{m}$ was captured and after settling over several days, the overlying clear water was decanted and the residue was oven-dried, weighted, and preserved in plastic boxes.

\section{Preparation of samples for morphometric analyses}

The $\geq 63 \mu \mathrm{m}$ size fraction was first inspected under the binocular microscope for abundance of menardiform globorotalids, carbonate preservation, and faunal content. Using a micro-splitter each sample was split to a manageable amount of foraminifera, which was the case when about 150-200 intact menardiform specimens could be picked from that subsplit. In most cases this amount was reached in aliquots of $1 / 8,1 / 16$ or 1/32 split.

Once a split was judged to contain sufficient menardiform specimens, tests were quantitatively handpicked under the binocular microscope and mounted to standard faunal Plummer cells from P.A.S.I. srl for morphometric analyses (subsequently called "morphometry slides"). For each sample an assemblage slide was prepared for documentation of the most age-diagnostic species present (see Table 2 in the electronic supplementary materials for stratigraphic distribution of identified species in assemblage slides). They were determined using the illustrations given in Kennett and Srinivasan (1983), Chaisson and Pearson (1997), or Bolli and Saunders (1985) and consulting the reference collection to the latter, curated at the Natural History Museum Basel.

In the morphometry slides, one specimen was fixed in keel position in the center of each field with water-soluble glue. A total of 5927 specimens were mounted and analyzed during the present study (i.e. 4669 specimens of $G$. menardii, 1042 specimens of G. limbata, and 216 specimens of $G$. multicamerata). Keel position means, that each specimen has its apertural face showing upwards to the observer, as good as possible, and its spiral side is always on the left side. This pre-positioning of specimens was followed in all previous morphometric studies about menardiform globorotalids (Knappertsbusch 2007; Brown 2007; Mary 2013; Mary and Knappertsbusch 2013, 2015).
The consequences of this protocol for sinistral and dextral coiling of tests upon analysis is described in a section further below. Pre-positioning also greatly facilitated automatic positioning of specimens under the binocular microscope with the Automated Measurement system for test mORphology called AMOR, that was used in the present study (Fig. 3a). White numerals engraved in the morphometry slides were previously blackened out using a felt-tip pen to prevent any optical misinterpretation during automated imaging with AMOR.

\section{Digital imaging and processing of images to morphometric data}

The AMOR device is driven by a LabView 8.5 application, that is also called AMOR, and that was developed in line with the physical device in collaboration with members of the Applied University of Northwestern Switzerland (Knappertsbusch et al. 2009). A technical description of this system and information about its precision and repeatability for automated specimen orientation is provided in that publication and in the dissertation of Mary (2013). In comparison to manipulating a specimen into the desired keel position under the binocular on a hemispherical stage by hand, the precision of automated orientation with AMOR has improved from 18.63 to $6.13 \mu \mathrm{m}$, i.e., by a factor of 3 (see tests described in Supplement \#5 of MorphCol of Knappertsbusch 2015a).

Positioning of menardiforms in keel view and automated digital imaging of specimens was mainly realized with software versions AMOR v. 3.17 and AMOR v. 3.28. In automatic mode, AMOR moves the stage from one specimen to the next under the binocular microscope, orients the specimen by pitch and roll movements into upright position, focuses, and captures an 8-bit gray-level Tiff image at the highest possible magnification. The optimum keel view is attained when the axial length of the test is maximized and its area in keel view is minimized. This procedure proved to work efficiently with biconvex, quasi-symmetric profiles and sub-elliptic shapes in equatorial view (such as those of $G$. menardii). In cases, where the profile was umbilico-convex (G. miocenica), spiroconvex (G. multicamerata) or approached a circular periphery in equatorial view, the orientation algorithm was only partially successful and specimens had to be orientated using the alternate manual mode of AMOR. A solution of this " $G$. miocenica-problem" became only later available in versions higher than AMOR v. 3.17 (see Supplement\#20 of Knappertsbusch 2015a).

An optimal illumination is of great importance to digital imaging. In most cases, a paired swan-neck fiber optics equipped with twistable polarizing caps was used for this purpose. Crossed polarized light was generated by fixing a 


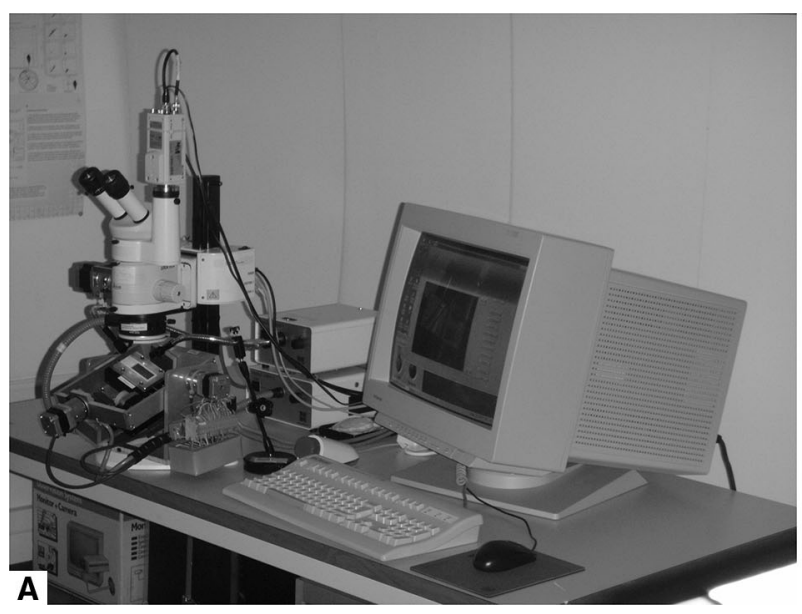

Fig. 3 a Automated measurement system for shell morphology (from AMOR), that was used for the present investigation. b Motorized tilting stage of AMOR, which is installed underneath the binocular microscope. It is equipped with an LED illumination, consisting of a removable frame holding 10 Moonstone $1 \mathrm{~W}$ Power LEDs. The frame with the LEDs moves together with the specimens while translating the stage in $X$ - and $Y$ direction or tilting the stage forwards-backwards

second polarizing filter inside of the objective of the microscope. This physical arrangement enhanced the contrast between the calcitic tests and the background while removing reflexions from the slide background and so facilitated the pre-processing of images prior to outline extraction. In cases of suboptimal illumination of a specimen (i.e., at high tilting angles of the stage or at highest magnifications) a removable LED illumination (Fig. 3b) was used for sufficient light intensity on the specimen. This LED illumination was at the cost of no cross-polarization because available LEDs do not emit polarized light in direction of the main light beam (Schubert et al. 2007).

Processing of tiff images was automated on a PC using AdobePhotoshop CS 5 v. $12.1 \times 64$ and the public domain software ImageJ v 1.48. Gray-level images from AMOR were first converted to binary (black and white) images and then saved as single channel 8-bit raw images with a size of $640 \times 480$ pixels. From the raw images cartesian outline coordinates of the microfossils were extracted using the program Trace_AMOR1_batch.out on a Macintosh computer. Outline extraction and determination of morphometric parameters were done in batch-processing. These steps were performed using a suite of customized Fortran programs called MorphCol (Knappertsbusch 2015a). These comprise the suite of applications MagCorr2.out, Trace_AMOR1_batch.out, Sprep5.3.out, KeelWidth13.out, Compose6.0.out, and DexFlip.out, which made processing of the thousands of images more efficient. The sequence of these programs is schematically illustrated in Fig. 1_suppl in the electronic supplementary materials. As an example for this workflow a processing log is given in Table 3 of

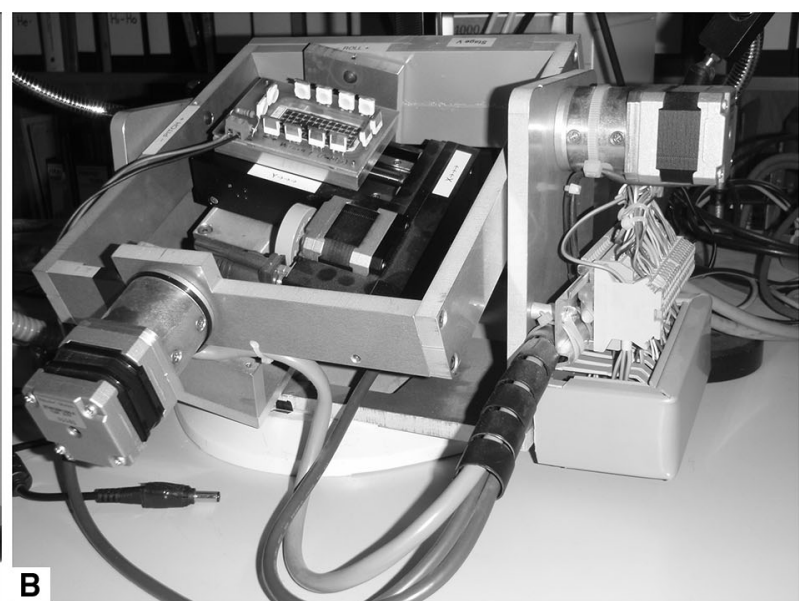

or from left to right (see Supplement\#22 in MorphCol of Knappertsbusch 2015a). The advantage of this installation is a constant light intensity on the specimens that is independent from the mechanical movement of the stage, in contrast to a standard illumination, where for example an external swan-neck fiber optics has a fix position with respect to the moving stage

the electronic supplementary materials. The program Sprep5.3 produced 250 equiangular points from the original outline file that was obtained with program Trace_AMOR1_batch.out. Auxiliary program DexFlip.out vertically mirrors coiling-dependent parameters for dextral tests. After combining measurements from individual tests to composed files per sample, data were statistically analyzed using STATISTICA v. 12 software from StatSoft. An electronic archive containing the generic codes of the MorphCol programs can be downloaded from http://doi. pangaea.de/10.1594/PANGAEA.848773.

Morphometric parameters taken include spiral height $\delta X$, axial length axial length $\delta Y$, the area enclosed by the perimeter in keel view (Ar), the upper and lower keel angles $\Phi_{1}$ and $\Phi_{2}$, respectively, the angle $\Phi_{3}$ at the apex, the spiral and umbilical convexities A and B, respectively, the radii $R_{\mathrm{up}}$ and $R_{\mathrm{lo}}$ of the osculating circles in the upper and the lower keel region, respectively (Fig. 4).

Most attention is given to spiral height $(\delta X)$ and axial length $(\delta Y)$ measurements, because much of the morphological variability of the G. menardii, G. limbata and $G$. multicamerata plexus can be described by this minimal set of variables (own unpublished experiments; Stewart 2003; Mary and Knappertsbusch 2013).

\section{Handling of sinistral and dextral coiling}

Tests of menardiform globorotalids show sinistral or dextral coiling, with varying proportions depending on species and geological age. Because in the present study specimens were standardly fixed in the slides with the spiral side 


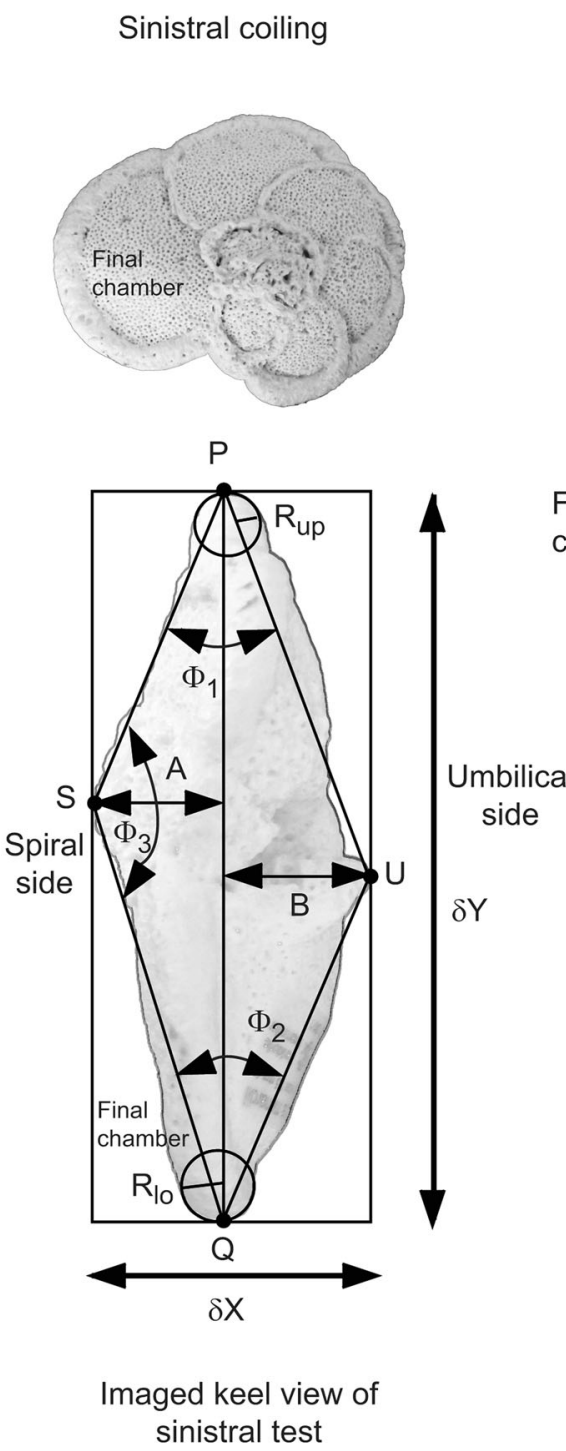

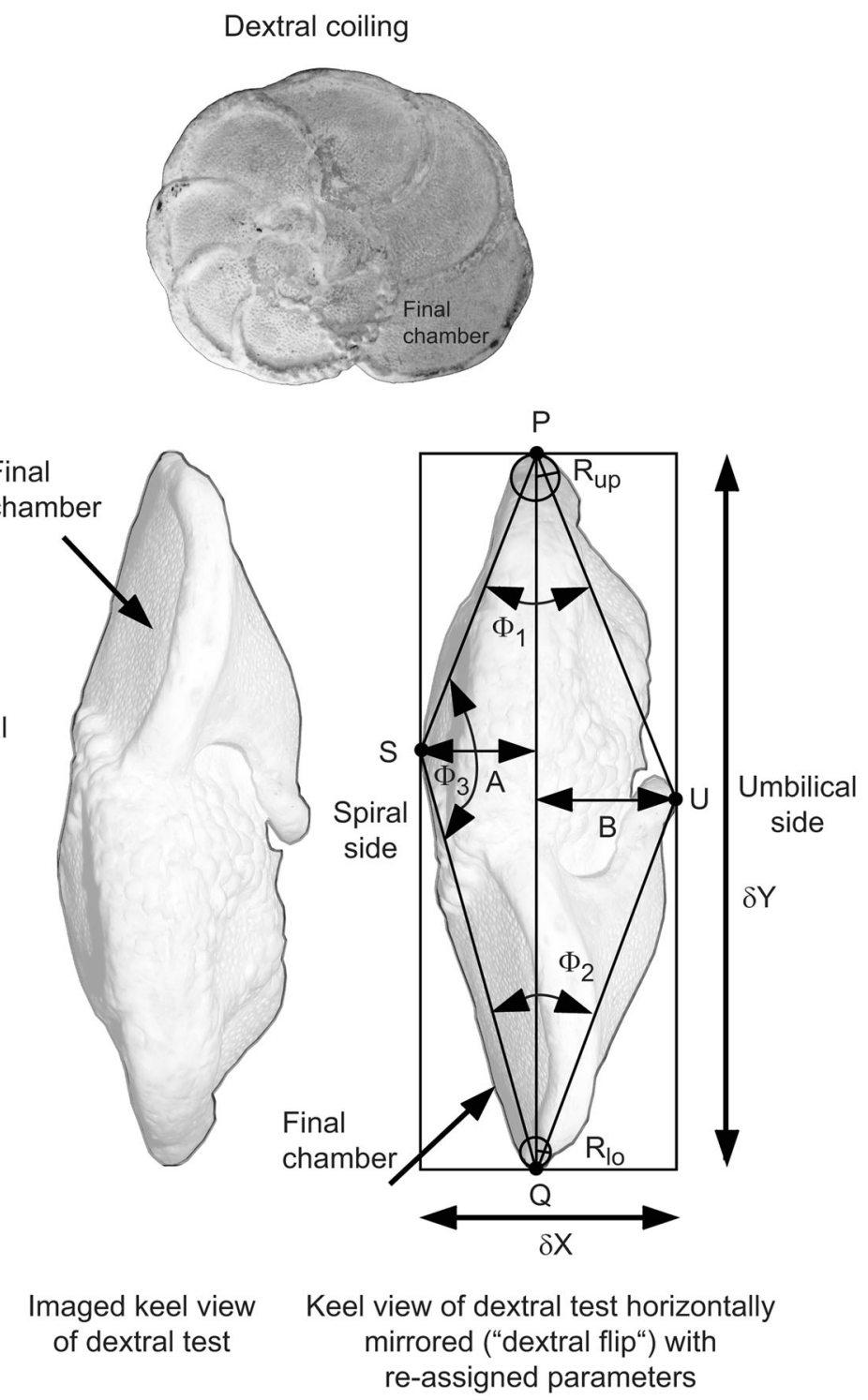

Fig. 4 Morphometric parameters investigated: $\delta X$ spiral height, $\delta Y$ axial length, $\Phi_{1}$ upper keel angle, $\Phi_{2}$ lower keel angle, $\Phi_{3}$ angle at the apex, $A$ spiral convexity, $B$ umbilical convexity, $R_{\text {up }}$ radius of the osculating circle in the upper keel region; $R_{\mathrm{lo}}$ radius of the osculating circle in the lower keel region. The specimen to the left illustrates assignment of parameters in keel view of a sinistral test (=standard imaging position). The representations in the middle and to the right show a dextral specimen in keel view as imaged with AMOR

always facing to the left side, the final chamber of a sinistral form is directed to the bottom of the image when seen in keel view, while in a dextral form the final chamber is directed to the top of the image (see Fig. 4). For the geometric analysis this difference must be accounted for if coiling-dependent parameters are considered. The herein illustrated parameters that depend on the coiling direction include the upper and lower keel angles $\Phi_{1}$ and $\Phi_{2}$, and the radii $R_{\text {up }}$ and $R_{\text {lo }}$ of the osculating circles in the upper and the lower keel regions. Coiling-invariant parameters (middle) and after dextral flip operation with re-assigned parameters (right). Note, that in the sinistrally coiled specimen the final chamber is facing to the bottom, while in the dextral specimen the final chamber in imaging position is facing to the top. After application of the dextral flip operation to the dextral specimen the final chamber is facing to the bottom, which then can be more easily compared to a sinistral specimen (see further explanations in the text)

include the spiral height $\delta X$, the axial length $\delta Y$, the area enclosed by the perimeter in keel view (Ar), the angle $\Phi_{3}$ at the apex, and the spiral and umbilical convexities A and B, respectively. In order to more easily compare geometric measurements from sinistral tests with dextral ones keel angles $\Phi_{1}$ and $\Phi_{2}$, were exchanged against each other for dextral specimens and the same was done for radii $R_{\mathrm{up}}$ and $R_{\mathrm{lo}}$. This "dextral flip" operation was performed with the auxiliary program DexFlip.out prior to calculation of statistics and plotting of data. Exchanging pairs of coiling- 
dependent variables is equivalent to mirroring dextral specimens about a horizontal plane with respect to these parameters. Alternatively, mirroring could also have been done in the original images prior to all analysis but for reference reasons the author preferred to keep original images in an unchanged format.

\section{Construction of contour diagrams}

It was already Schmid (1934) who recognized contoured frequency diagrams useful to quantify the test morphology of G. menardii and G. tumida from the Pliocene Fufa Marls of Ceram (Indonesia). Nevertheless, the potential of this method remained unnoticed for very long time, at least for planktic foraminifera. Own investigations have confirmed, that contour diagrams are helpful to track distributions of spiral height $(\delta X)$ versus axial length $(\delta Y)$ through geography and time (Knappertsbusch 2007; Brown 2007; Knappertsbusch and Mary 2012). Bivariate contour plots of $\delta X$ versus $\delta Y$ for each sample were, therefore, prepared using the gridding tool Grid2.out described in the MorphCol 2004-2013 documentation in Knappertsbusch (2015a) and using the same grid cell dimensions $(\Delta X=100 \mu \mathrm{m}, \Delta Y=50 \mu \mathrm{m})$ as in the earlier studies. Control experiments confirmed robust modal center coordinates with that grid cell size.

\section{Construction of volume density diagrams}

Volume density diagrams are an extension of two-dimensional contour diagrams to a higher dimension. They are helpful to analyze and display morphometric measurements through time (Knappertsbusch and Mary 2012). This technique is further explored for Hole 925B in the "Results" and "Discussion" sections. Volume density diagrams were constructed using the above-mentioned gridding matrices for $\delta X$ and $\delta Y$ per sample and species. Using the auxiliary program Grid_to_Vox3.out gridding matrices from individual samples were merged and reformatted to form a single matrix consisting of $\Delta X$ (increments of spiral height), $\Delta Y$ (increments of axial length), Time, and local frequency $F_{i, j}$ (i.e., the number of specimens per grid cell of species $i$ in sample $j$ ). This new matrix was loaded to the 3D display software Voxler 2 from Golden Software, Inc. to generate specimen frequency iso-surfaces in the $\delta X, \delta Y$ space through time. After completion, the iso-surfaces can be animated in Voxler and inspected on the computer monitor under any desired angle of view. To make the diagrams better comparable to other sites values of spiral height and axial width were scaled to obtain values between 0 and +1 by dividing them through the maximum $\Delta X$ value (675) and the maximum $\Delta Y$ value (1550), respectively. Through this operation, the frequency distributions become arranged and centered around the diagonal line, which extends from the origin of the diagram with coordinates at $(0,0)$ to the point with coordinates $(1,1)$. The time axis was scaled by division of age by the maximum common age of the samples previously investigated at DSDP Sites 502 and 503 and at ODP Hole 925B studied here, which was $8 \mathrm{Ma}$. Local absolute specimen frequencies $\left(F_{i, j}\right)$ were transformed to relative frequencies $\left(V_{i, j}\right)$ using the formula $F_{i, j} * 100 / N_{\text {tot } j,}$, with $N_{\text {tot }, j}$ being the sum of specimens of all menardiform species (1) encountered in sample $j$. This frequency normalization allows comparison of volume densities across samples. These scaled and normalized data were fed to Voxler 2, and normalized volume density surfaces through time were constructed separately for G. menardii, G. limbata, and $G$. multicamerata. In Voxler, the imported relative frequencies were re-gridded at finer spatial intervals using isotropic inverse distance interpolation at a power of 2 without smoothing.

\section{Deposition of materials and data}

All sample residues and slides with picked and measured specimens are deposited in the micropaleontological collections of the Natural History Museum in Basel (NMB). The AMOR device is also held at the NMB. Digital images, extracted data, and MorphCol software are stored on CD-Roms, which are deposited alongside the micropaleontological collections, but also on the mediaserver at the NMB. Digital images, all raw data that were extracted from the foraminiferal images from Hole 925B prior to dextral coiling correction, and gridding matrices for $\delta X$ and $\delta Y$ are also deposited as an archive at www.pangaea.de (Knappertsbusch 2015b). Note, that the herein discussed and illustrated measurements are all after correction for dextral coiling and are reproduced in Tables $4 \mathrm{a}-\mathrm{c}$ and $5 \mathrm{a}-\mathrm{c}$ in the electronic supplementary materials. Table $4 \mathrm{a}-\mathrm{c}$ show measurements and observations of individuals composed for G. menardii, G. limbata, and G. multicamerata, respectively. Statistics of measurements per sample and per group are given in Table 5a-c for G. menardii, G. limbata, and G. multicamerata, respectively. Also from Table 5a-c the proportions of the number of dextrally coiling specimens $\left(\mathrm{N}_{\mathrm{dex}}\right)$ per sample can be read for G. menardii, $G$. limbata, and G. multicamerata, respectively. Table 6 explains the variables listed in Tables 4 and 5, as well as additional variables not further discussed in the text. In Table 7a through $\mathrm{g}$ of the electronic supplementary materials the scaled and normalized frequencies $\left(V_{i, j}\right)$, that were entered into Voxler for construction of volume density diagrams are tabulated for G. menardii, G. limbata, and $G$. multicamerata. 


\section{Taxonomical concepts}

The taxonomic and phylogenetic position of Globorotalia menardii and related forms caused much historical dispute and confusion on its nomenclature (Stewart 2003; Brown 2007). A review about the various opinions is, therefore, considered appropriate here.

The genus Globorotalia Cushman (1927) comprises Globigerinacea with a trochospiral test having an interiomarginal, umbilical-extraumbilical primary aperture (Blow 1969, 1979). Particularly Neogene forms have a smooth wall, non-spinose, with a microstructure of very thin nearly parallel crystals of calcite, the surface commonly developing crusts, ridges and pustules, and the edge keeled (Bandy 1972). On the basis of the presence or absence of a peripheral keel Blow $(1969,1979)$ subdivided the Neogene representatives of Globorotalia into the two subgenera Globorotalia (Globorotalia) and Globorotalia (Turborotalia), respectively (Kennett and Srinivasan 1983). Blow's suggestion raised nomenclatoric questions because, for example, of the different phylogenetic positions of non-keeled Globorotalia (Turborotalia) peripheroronda and the keeled Globorotalia (Globorotalia) fohsi robusta, which together formed a gradational evolutionary lineage or bioseries sensu Vella (1963). In order to circumvent such difficulty, Bandy (1972) proposed to split the Neogene globorotalids into four subgenera Fohsella, Menardella, Globorotalia and Hirsutella, which were later extended by Globoconella (Bandy 1975), Tenuitella (Fleisher 1974), and Jenkinsella (Kennett and Srinivasan 1983). This scheme is propagated in the phylogenetic atlas of Kennett and Srinivasan (1983), which is still widely used. It subsumes the two bioseries of $G$. (Menardella) menardii-limbata-multicamerata (see Fig. 18), and G. (M.) limbata-exilis-miocenica-pertenuis (see Fig. 19) into the Menardella clade, which are typical representatives in Neogene tropical to subtropical deep-sea sediments. Chaisson (2003) also adopted the concept of Kennett and Srinivasan (1983); however, with the modification that M. miocenica evolved from M. limbata instead from M. exilis. Chaisson (2003) pointed to ultrastructural differences between menardellids with Miocene origination and those with Pliocene origination: The former (the M. menardii-limbata-multicamerata bioseries) is normally perforate, often covered with a crust and cosmopolitan, while the latter (M. exilispertenuis, and $M$. miocenica) are finely perforate, uncrusted and endemic to the Atlantic.

Bandy's (1972) subgenus Globorotalia (Globorotalia) contains the genus type species Pulvinulina menardii (d'Orbigny) var. tumida Brady 1877 (as cited in Bolli and Saunders 1985) (see Fig. 20). The keeled G. (Globorotalia) merotumida-plesiotumida-tumida tumida-tumida flexuosa, and G. (Globorotalia) ungulata are considered descendents from the non-keeled G. (Globorotalia) lenguaensis-paralenguaensis group. In practice, however, the difficulty exists, that considerable morphological intergradation occurs between $G$. (Menardella) menardii and $G$. (Globorotalia) tumida tumida, already observed by Schmid (1934), Brown (2007), and during own investigations. In the opinion of the author this integradation questions the need of maintenance of the subgenus Menardella versus Globorotalia.

In Cifelli and Scott (1986) the menardiform branch is discussed on the basis of spiral chamber shapes. These authors accepted Bandy's (1972) idea of the menardines rooting from $G$. praescitula, but they only partially followed the subgeneric distinction of Globorotalia into the four groups proposed by Bandy. In the case of the menardine branch, Cifelli and Scott (1986) continued-as did Bolli and Saunders (1985, see further below) to use Globorotalia as a subgenus name.

Stainforth et al. (1975) did not distinguish between $\mathrm{Me}$ nardella and Globorotalia at all and lumped them together and used the informal term "menardiform" to describe a subgeneric group of keeled Neogene globorotalids.

Bolli and Saunders (1985) also refused Bandy's (1972, 1975) and Kennett and Srinivasan's (1983) subgeneric splitting, but kept on maintaining the subgenus Globorotalia (Globorotalia) sensu Blow (1969, 1979). Bolli and Saunders (1985) also questioned Stainforth et al.'s (1975) idea of Globorotalia (prae) scitula being the root of the earliest menardiform line. Likewise, the interpretation of Banner and Blow (1965) and Blow (1969) on the evolutionary sequence Globorotalia lenguaensis-paralenguaensis-merotumida-plesiotumida-tumida is not shared by Bolli and Saunders (1985), leaving the menardine origin unresolved. Within the menardiform taxa, however, Bolli and Saunders (1985) distinguished three end member lineages, the Pliocene G. pseudomiocenica-miocenica and $G$. multicamerata-pertenuis-exilis lines, and the Late Miocene to Holocene G. merotumida-plesiotumida-tumida tumida-tumida flexuosa group. In their view these lineages developed from a Middle-Late Miocene to Early Pliocene "G. menardii stock" beginning with the plexus of $G$. archeomenardii to G. praemenardii, which then continued to evolve into "G. menardii sensu lato". This G. menardii sensu lato comprised the smaller G. menardii 'A' with 5-6 chambers in the final whorl and the somewhat larger $G$. menardii ' $B$ ' having $7-71 \frac{1}{2}$ chambers in the final whorl (Bolli 1970). Because of the still unclear situation and in absence of biometric comparisons within the menardiform groups at that time, these authors continued to subdivide the G. menardii complex into Miocene to Early Pliocene 
Globorotalia ' $A$ ' and ' $B$ ' and Pliocene to extant $G$. menardii menardii and G. menardii cultrata.

Meanwhile extended morphometric studies were realized (Stewart 2003; Brown 2007; Knappertsbusch 2007; Mary 2013; Mary and Knappertsbusch 2013, 2015) documenting the strong morphological intergradation between menardiform taxa. There is still large taxonomic and phylogenetic uncertainity in this group. Without knowledge about the connection between genetic and morphologic variability of modern G. menardii, similar to those recently described in Globigerinella (Weiner et al. 2015) the author refrains from revising the menardiform taxonomy. Instead, the nomenclatural concept and phylogenetic model of Bolli and Saunders (1985) is broadly followed here, as was practised in the precedent study of Knappertsbusch (2007). Similar to that study, the extinct Globorotalia 'A' (Bolli 1970) and Globorotalia 'B' (Bolli 1970) are considered to represent evolutionary early forms of G. menardii menardii and a junior synonym of G. limbata Fornasini (1902), respectively.

\section{Practical constraints in taxonomic investigation}

Menardiform globorotalids show extreme variation, which makes distinction of closely related species difficult. Juveniles to pre-adult stages, which co-occur in samples, often lack species-diagnostic characters above the ultrastructural level. Therefore, species can only reliably be separated in adults where diagnostic characters are better developed. In practice, one has to identify adult stages within an often broad and continuous size spectrum. Detailed investigations such as the construction of ontogenetic growth curves are necessary to resolve this difficulty, as was exemplified by Hohenegger (2014) in benthic foraminifera. In the case of menardiforms the less distinctive pre-adults dominate juveniles or adults leading to masking of morphometrical signals from the juvenile and adult stages by those of pre-adults. Such difficulties amplify in fossil assemblages when menardiform diversity increases such as in Pliocene samples. Using a population-based taxonomy approach in a global mid-Pliocene time-slice (i.e., in the absence of evolutionary time) and applying ontogenetic considerations Mary (2013), Mary and Knappertsbusch (2013, 2015) attempted to overcome some of these problems. The effort for this approach is exorbitantly high because multiple size fractions made extremely large specimen numbers per sample (up to 720 specimens!) necessary. Moreover, in studies through geological time this population-based taxonomy approach is not appropriate because populations (species) evolved. This is why the morphometric analysis of samples was performed on one single size fraction $>63 \mu \mathrm{m}$.
In order to meet the required stratigraphic resolution smaller specimen numbers (150-200) per sample were accepted to be sufficient. The consequence for this decision was that the above-mentioned population-based taxonomy approach could not be followed. Classification into taxonomic groups was, therefore, made visually prior to morphometric measurements. Following this reasoning species were identified using traditional descriptions, illustrations and plates given in Blow (1979), Cifelli and Scott (1986), Kennett and Srinivasan (1983), and Bolli and Saunders (1985). This approach may induce bias in taxonomic interpretation and expertise by the investigator, but is considered acceptable for this exploratory work because all specimens were classified by the same person.

Globorotalia menardii was identified as forms with a biconvex profile in keel view and with up to six chambers in the final whorl. It includes the small $G$. menardii ' $A$ ' of Bolli (1970), G. menardii menardii, and G. menardii cultrata (see 1-7 on Fig. 18). From G. menardii other Quaternary subspecies were described including $G$. menardii fimbriata (Brady) typically occurring during the Holocene in Caribbean sediments (see Bolli and Saunders 1985), G. menardii gibberula, which is restricted to the Indian Ocean and the South Atlantic (Bé 1977), and G. menardii neoflexuosa, which was found alive and from the Sangamon Interglacial and the warm interstadial of the last ice age in the northern Indian Ocean (Srinivasan, Kennett and Bé 1974).

In contrast to the phylogenies proposed in Kennett and Srinivasan (1983), or Cifelli and Scott (1986), Bolli and Saunders (1985) did not distinguish G. limbata as a separate species between $G$. menardii and $G$. multicamerata.

In practice, G. limbata is difficult to keep apart from $G$. menardii. Limbation of the chamber sutures, the diagnostic feature of $G$. limbata, is found to be a poor qualitative separator against G. menardii (Brown 2007; Mary 2013, own observations). Knappertsbusch (2007) supposed that G. menardii ' $B$ ' (Bolli 1970) is a junior synonym of $G$. limbata. These and the author's own unpublished observations from surveys on Holocene G. menardii and from ODP Site 925 suggest that adult $G$. limbata can at best be differentiated from $G$. menardii in having seven chambers in the final whorl (10-12 on Fig. 18). In Holocene sediments adult $G$. menardii do not exceed six chambers in the final whorl. At ages from 7.96 to $5.27 \mathrm{Ma}$ G. limbata was found to coil mostly sinistrally, while at younger levels dextral coiling dominated for this species at ODP Site 925.

Globorotalia multicamerata is best recognized in the final whorl by the presence of eight or more chambers (13-15 on Fig. 18). In almost all samples tests of $G$. multicamerata showed dextral coiling. G. multicamerata is distinguished from co-existing $G$. miocenica by its lenticular, biconvex profile in keel view and a distinct rounded 
peripheral keel. In contrast G. miocenica is strongly umbilico-convex in keel view with a distinctly flattened spiral side and shows a very acute peripheral keel (7-9 on Fig. 19). Representatives of the G. exilis-G. pertenuis lineage include strongly flattened but biconvex forms with a finely perforate, highly reflective "shiny" test surface (1-6 on Fig. 19).

The reader may bear in mind that the present contribution serves as a morphometric exploration about test variation in the plexus of $G$. menardii-G. limbata-G. multicamerata from ODP Site 925 rather than being taxonomically conclusive. Pending future investigations it may well be that a thorough taxonomic revision of the menardiform clade will become unavoidable for this group, but as will be demonstrated with the results in the following sections our knowledge is still too limited for arriving at such a conclusion.

\section{Results}

\section{Evolution of morphological parameters in the G. menardii-limbata-multicamerata lineage}

In the sections to follow, main focus will be given to the spiral height $(\delta X)$ versus axial length $(\delta Y)$ measurements through time. The temporal variation of selected other measurements are also considered here in order to better assess basic evolutionary patterns within the lineage. As will be seen further below, not all of the measured parameters are ideal when divergence is sought between possibly closely related species. It is the art of experimentation with the data to tease out the most promising signals that eventually may help to decipher speciation patterns. However, a complete analysis including all combinations of measured parameters is beyond the scope of the present exploration and must be reserved for yet another study.

A simple first-order indicator for test variation of $G$. menardii through time from ODP Hole 925B is the mean keel view area, which is illustrated in Fig. 5a. Overall, the mean keel view area of $G$. menardii changed rather gradually between $8 \mathrm{Ma}$ to Recent. The net mean increase within that time span to a mean size of $0.0984 \mathrm{~mm}^{2}$ in the youngest sample is about $0.0541 \mathrm{~mm}^{2}$, which is more than twice the initial size at $8 \mathrm{Ma}\left(0.0443 \mathrm{~mm}^{2}\right)$. During the first 3.6 Myrs (i.e. from $8 \mathrm{Ma}$ to $4.62 \mathrm{Ma}$ ) this increase was nearly constant with the exception of the sample at $5.78 \mathrm{Ma}$, when G. menardii grew larger for a short interval. After a size reduction (4.35 Ma) G. menardii tests increased again, but then started to reverse the mean size trend for a longer period until $2.59 \mathrm{Ma}$.

Between 2.59 and 2.3 Ma G. menardii was very rare and only small forms were present. From 2.3 to 1.95 Ma mean test sizes increased significantly and persisted until Recent. More fluctuation from one sample to the next is seen in the course of the upper quartiles, the $90 \%$ sample percentiles, and most dramatically in the upper extremes of the keel view area (Fig. 5a). Noticeable is the increase of the maximum keel view area between 2.3 and $1.95 \mathrm{Ma}$, after a series of menardii-barren intervals from 2.266 to $2.057 \mathrm{Ma}$ (horizontal gray stripes in Fig. 5). In contrast, the minima of these spectra showed little variation, which is also due to utilization of a minimum mesh-size of sieves at $63 \mu \mathrm{m}$.

In G. limbata (Fig. 5b), mean keel view areas were slightly larger and parallel the size evolution of $G$. menardii. Also $G$. limbata experienced a quite gradual increase in mean keel view area from 7.96 to $4.62 \mathrm{Ma}$, but then and after a strong incursion at $4.35 \mathrm{Ma}$ showed a period of strong mean size increase of $>180 \%$ within only $0.36 \mathrm{Myrs}$ (i.e. from $0.0596 \mathrm{~mm}^{2}$ at $4.35 \mathrm{Ma}$ to $0.108 \mathrm{~mm}^{2}$ at $3.99 \mathrm{Ma}$, see Fig. 5b). Thereafter, until $2.88 \mathrm{Ma}$ the mean keel view area trend reversed, similar to G. menardii. Globorotalia limbata occurred in nearly every sample from $7.96 \mathrm{Ma}$ core-upwards, but became very rare in levels younger than about 2 Ma. Chaisson and Pearson (1997) reported the highest occurrence of rare G. limbata at ODP Hole $925 \mathrm{~B}$ at $3.25 \mathrm{Ma}$ (sample 925B-11-5, 65-67 cm). In the present study abundant $G$. limbata were still detected at $2.88 \mathrm{Ma}$ (sample 925B-10-4, 126.5-127.5 cm). In the sample 925B-9-5, 65-67 cm of Chaisson and Pearson (1997), which has an age of $2.59 \mathrm{Ma}$, G. limbata was reported absent. In five samples higher up in the core (i.e., at $1.95 \mathrm{Ma}, 1.65 \mathrm{Ma}, 0.86 \mathrm{Ma}, 0.33 \mathrm{Ma}$ and at $0.20 \mathrm{Ma}$ ), G. limbata was very rare and occurred only as single specimens $(<0.6 \%)$, possibly indicating reworking. The extinction interval (pseudoextinction sensu Newman and Palmer 2003) of G. limbata at Hole 925B is hence considered between 2.88 and $2.59 \mathrm{Ma}$.

Small specimens of G. multicamerata, the end member of the G. menardii-G. limbata-G. multicamerata lineage, were first recorded together with similarly small $G$. menardii and $G$. limbata in the sample at $6.07 \mathrm{Ma}$ (Fig. 5c). From about $5 \mathrm{Ma}$ section upwards, G. multicamerata with eight or more chambers in the last whorl developed into larger forms until the sample at 3.99 Ma at an even higher rate and a more interpunctated manner than G. limbata. Thereafter, this trend reversed until (pseudo) extinction (see Fig. 5c, compare also with contour diagrams of $\delta X$ vs $\delta Y$ in Fig. 14 to follow). The stratigraphically youngest specimens of $G$. multicamerata were detected in sample 925B-10-4, 126.5-127.5 cm (2.88 Ma), which is slightly younger than the youngest specimens found by Chaisson and Pearson (1997) at $2.91 \mathrm{Ma}$ in sample 925B-10-5, 65-67 cm. Together, these observations constrain the (pseudo) extinction interval of $\mathrm{G}$. multicamerata at Hole 925B to between 2.88 and $2.59 \mathrm{Ma}$, 


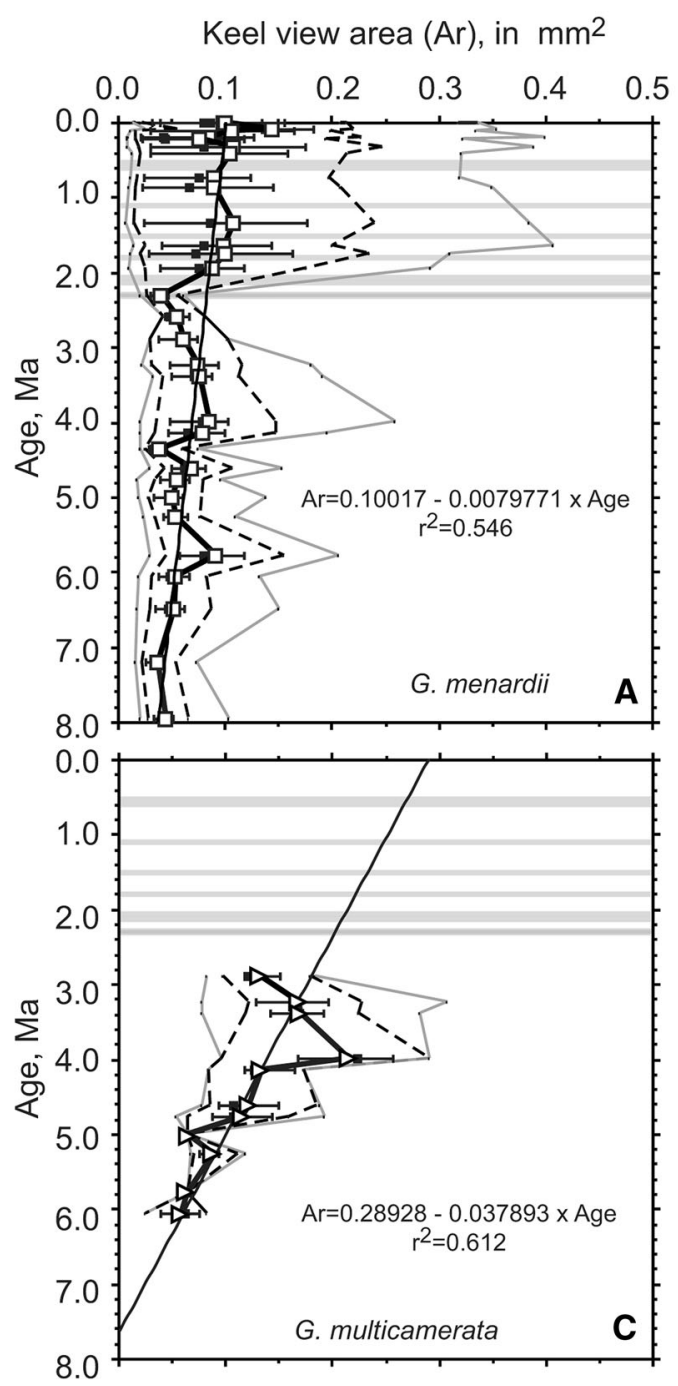

Keel view area $(\mathrm{Ar})$, in $\mathrm{mm}^{2}$

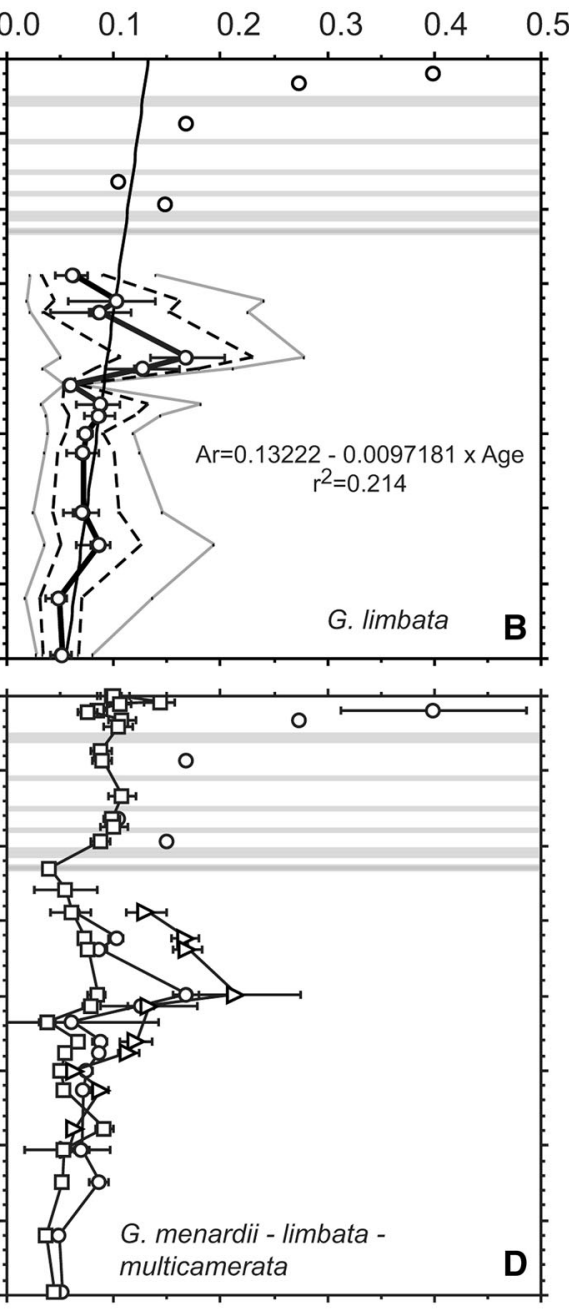

Fig. 5 Means of cross-sectional area in keel view (in $\mathrm{mm}^{2}$ ) through time (in Myrs) at Hole 925B for G. menardii (a), G. limbata (b), G. multicamerata (c), and the comparison of the three groups (d). Squares G. menardii (including G. menardii cultrata, G. menardii menardii, G. gibberula, transitional forms between $G$. menardii-G. exilis, G. menardii-G. pseudomiocenica, and G. menardii-limbata), circles $G$. limbata; triangles $G$. multicamerata. Open symbols are means. In a-c horizontal bars indicate the range from the lower to upper quartiles of the samples, and filled black squares represent sample medians. Left and right gray lines are sample minima and maxima, respectively. Dashed lines indicate 10 and $90 \%$ sample percentiles. In a-c linear regression lines are drawn through sample means with equations indicated, and values of $r^{2}$ are linear regression coefficients. In case of $G$. limbata the single specimens of the five uppermost samples (i.e. at 1.95, 1.65, 0.86, 0.33 and at $0.20 \mathrm{Ma}$ in

which is coeval to the extinction of G. limbata at this location.

Figure $5 \mathrm{a}-\mathrm{c}$ show a flattening of the slopes of the regression lines through the means of keel view area from $G$. menardii to $G$. multicamerata, with $G$. limbata being intermediate. When the three curves of means are b and d) were omitted for the calculation of the regression line because reworking cannot be excluded for these specimens, see explanation in the text. The same applies to the following Figs. 6, 7, 8, 9, 10 and 11. In $\mathbf{d}$ sample means are re-plotted together for $G$. menardii, G. limbata and G. multicamerata for easier comparison, with horizontal bars indicating $\pm 95 \%$ confidence intervals around the means per group. Gray shaded horizontal stripes represent intervals barren in menardiform globorotalids $(0.51,0.61,1.12,1.47$, $1.8,2.057,2.154,2.24,2.266$, and 2.91 Ma. Information for horizons at 0.61, 2.24 and 2.91 Ma are from Chaisson and Pearson (1997). Individual measurements are given in Table $4 a-c$. Statistics can be read from Table $5 \mathrm{a}-\mathrm{c}$. Table 6 provides explanations to these data. Tables $4 a-c, 5 a-c$, and 6 can all be found in the electronic supplementary material

superposed, a splitting pattern emerges with respect to mean keel view area leading to accelerated divergence of G. limbata and G. multicamerata from the G. menardii root between 5.0 and $3.99 \mathrm{Ma}$ (Fig. 5d). In search for support of these observations, the trends of the mean radii of the osculating circle in the upper keel region $\left(R_{\text {up }}\right.$ in Fig. 6a-d) 
Radius upper osculating circle $\left(R_{\mathrm{up}}\right), \mu \mathrm{m}$ Radius upper osculating circle $\left(\mathrm{R}_{\mathrm{up}}\right), \mu \mathrm{m}$
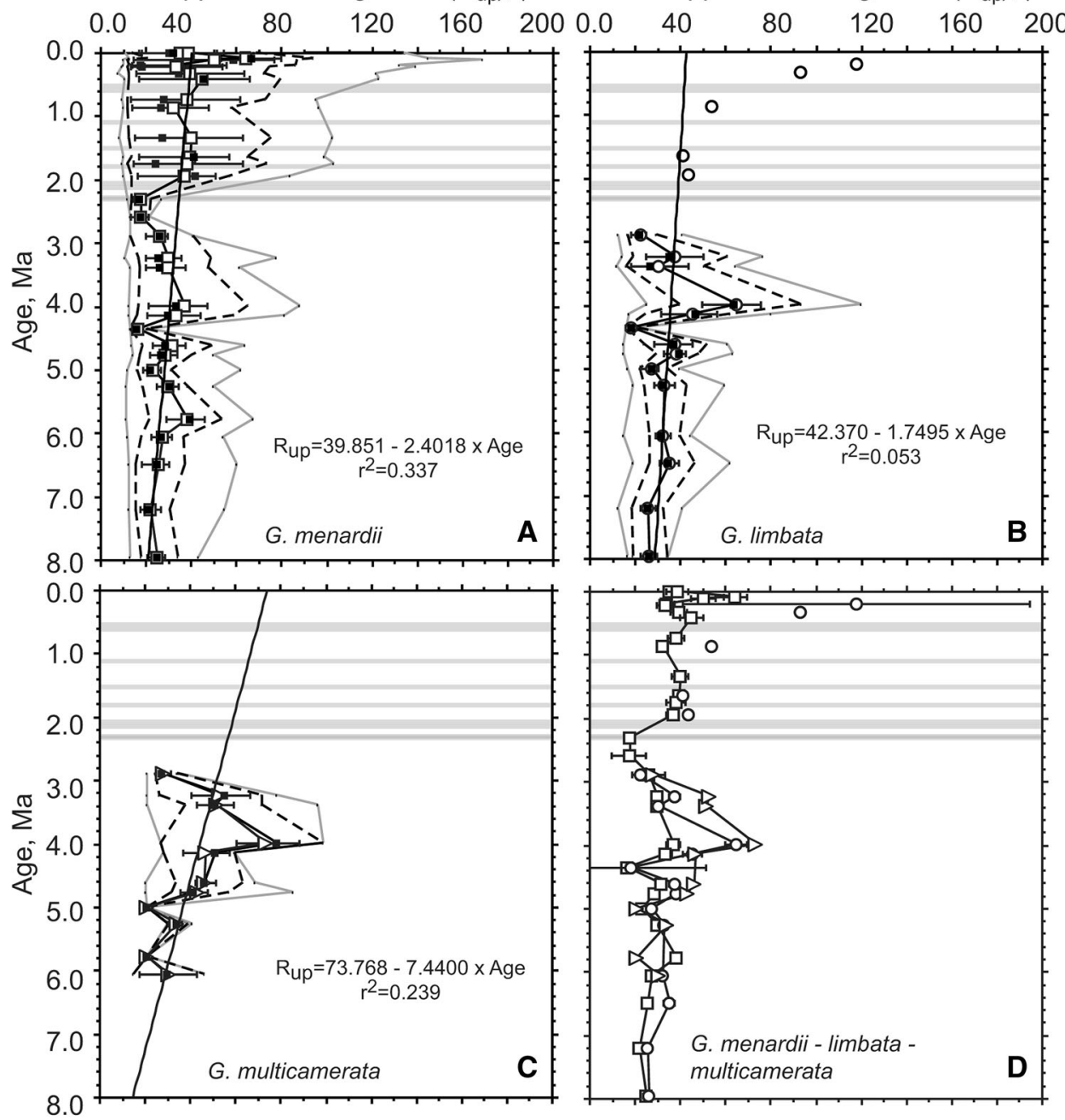

Fig. 6 Mean radius of the upper osculating circle $\left(R_{\text {up }}\right)$ in keel view $(\mu \mathrm{m})$ per sample through time (Ma) at Hole 925B for G. menardii (a), G. limbata (b), and G. multicamerata (c). In $\mathbf{d}$ means of $R_{\text {up }}$ of the three groups are compared to each other. See Fig. 5 for explanation of

and of the mean spiral convexity (A in Fig. 7a-d) show a similar behavior. Both parameters display accelerated divergence in G. limbata and G. multicamerata from $G$. menardii between about 5 and 3.99 Ma. Notably G. multicamerata began to increase in mean A between 6.07 and 5.78 Ma and exhibits strongest divergence in mean A from 5 to $3.99 \mathrm{Ma}$ (Fig. 7c). Also the prominent expansion of maximal $R_{\text {up }}$ and A post $2.3 \mathrm{Ma}$ is a recurrent feature when considered together with the curve of maximum keel view area. It documents a tendency to develop a thickened peripheral keel and a higher coiling on the spiral side during the younger time of menardiform evolution.

In the lower osculating circles, trends for mean radii and extrema are also comparable to the above patterns, though with a minor net change, especially during the first 3.34 myrs (7.96-4.62 Ma) in all three forms (Fig. 8a-d). symbols. For explanation of the radius of the upper osculating circle $R_{\text {up }}$ refer to Fig. 4. Measurements and statistics can be read from Tables $4 \mathrm{a}-\mathrm{c}$ and $5 \mathrm{a}-\mathrm{c}$ in the electronic supplementary materials

Experiments were also carried out with means of the ratio of spiral convexity (A) to umbilical convexity (B) in keel view (Fig. 9). It was found, that the ratio of $\mathrm{A} / \mathrm{B}$ is ideal for showing the intermediate position of G. limbata between G. menardii and G. multicamerata. Interestingly, the divergence of $G$. multicamerata in the ratio of $\mathrm{A} / \mathrm{B}$ culminates at $3.39 \mathrm{Ma}$, which is 0.6 myrs later than similar trends in the previously discussed parameters. After 3.39 Ma the ratio A/B strongly declines possibly indicating dwarfing due to environmental stress prior to extinction of G. multicamerata. Dwarfing was also observed in other Cenozoic planktic foraminifers (Wade and Olsson 2009).

Upper and lower keel angles $\left(\Phi_{1}\right.$ and $\Phi_{2}$, respectively, see Fig. 4) were determined in order to better discriminate between $G$. limbata and G. multicamerata against contemporaneous G. menardii. All three forms show almost 
Fig. 7 Mean spiral convexity (a) as seen in keel view $(\mu \mathrm{m})$ through time (in Ma) at Hole 925B for G. menardii (a), $G$. limbata (b), and $G$. multicamerata $(\mathbf{c})$. In $\mathbf{d}$ mean spiral convexities of the three groups are compared to each other. Same explanation for symbols as in Fig. 5. Horizontal bars in $\mathbf{a}-\mathbf{c}$ are quartile ranges, while in $\mathbf{d}$ horizontal bars represent $\pm 95 \%$ confidence intervals around the means. For explanation of spiral convexity (a) refer to Fig. 4.

Measurements and statistics can be read from Tables 4-c and 5$\mathrm{c}$ in the electronic supplementary materials
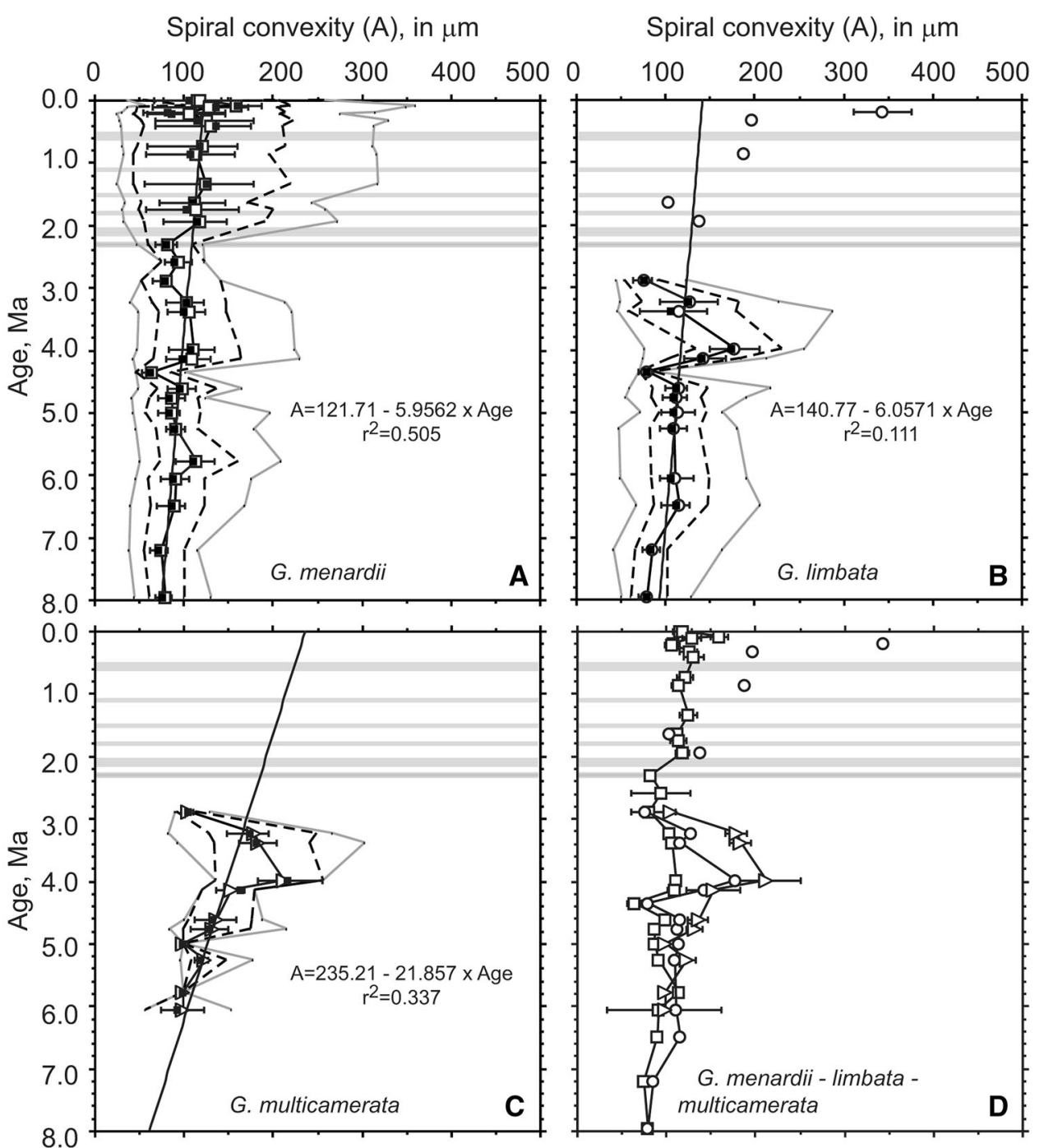

identical values of mean $\Phi_{1}$ in a particular sample and no clear differentiation is possible (Fig. 10). In contrast, means of the lower keel angle $\left(\Phi_{2}\right)$ tended to be always low, intermediate and higher between 5.78 and $3.23 \mathrm{Ma}$ for G. multicamerata, G. limbata and G. menardii, respectively (Fig. 11).

\section{Evolution of contoured frequency diagrams of spiral height $(\delta X)$ versus axial length $(\delta Y)$}

In order to compare test size variation of $G$. menardii, $G$. limbata, and G. multicamerata of the present investigation with trends in spiral height $(\delta X)$ and axial length $(\delta Y)$ described earlier from Caribbean Sea DSDP Site 502 and from Eastern Equatorial Pacific DSDP Site 503 (Knappertsbusch 2007) similar contoured frequency diagrams were prepared for each species and per sample at ODP Hole 925B (Figs. 12, 13, 14).

\section{Contoured diagrams of spiral height $(\delta X)$ versus axial length $(\delta Y)$ for $G$. menardii}

In case of G. menardii, the specimens are distributed along a diagonal band in the spiral height $(\delta X)$ versus axial length $(\delta Y)$ plane when followed through time (Fig. 12). Size expansion is, thus, not isotropic but shows a preferred, almost linear trend indicating test flattening, as individuals get larger and ontogenetically more mature. At the individual sample level $\delta X$ versus $\delta Y$ distributions have often skew to the right (positive skew), with a main frequency maximum not larger than $200 \mu \mathrm{m}$ along the axis of spiral height $(\delta X)$. In sediments younger than 2.3 Ma until Recent, the distributions become rapidly more expanded to larger values of spiral height. They often show a secondary mode at a spiral height in the vicinity $300 \mu \mathrm{m}$ (Fig. 12), next to the primary mode within the first $200 \mu \mathrm{m}$ of spiral height. This pattern is not a sampling artifact but reflects the 
Fig. 8 Mean radius of the osculating circle in the lower keel region $\left(R_{\mathrm{lo}}\right.$, in $\left.\mu \mathrm{m}\right)$ for $G$. menardii (a), G. limbata (b), and G. multicamerata (c) through time (in Ma) at Hole 925B. See Fig. 4 for explanation of parameters. In ac horizontal bars are quartile ranges while in $\mathbf{d}$ they represent $\pm 95 \%$ confidence intervals around the means. For explanation of symbols see Fig. 5. Please note the reduced scale on the horizontal axis in comparison to the radii of upper osculating circles in Fig. 6. Data and statistics can be read from Tables $4 \mathrm{a}-\mathrm{c}$ and $5 \mathrm{a}-\mathrm{c}$ in the electronic supplementary materials
Radius lower osculating circle $\left(\mathrm{R}_{1 \mathrm{lo}}\right), \mu \mathrm{m}$ Radius lower osculating circle $\left(\mathrm{R}_{10}\right), \mu \mathrm{m}$
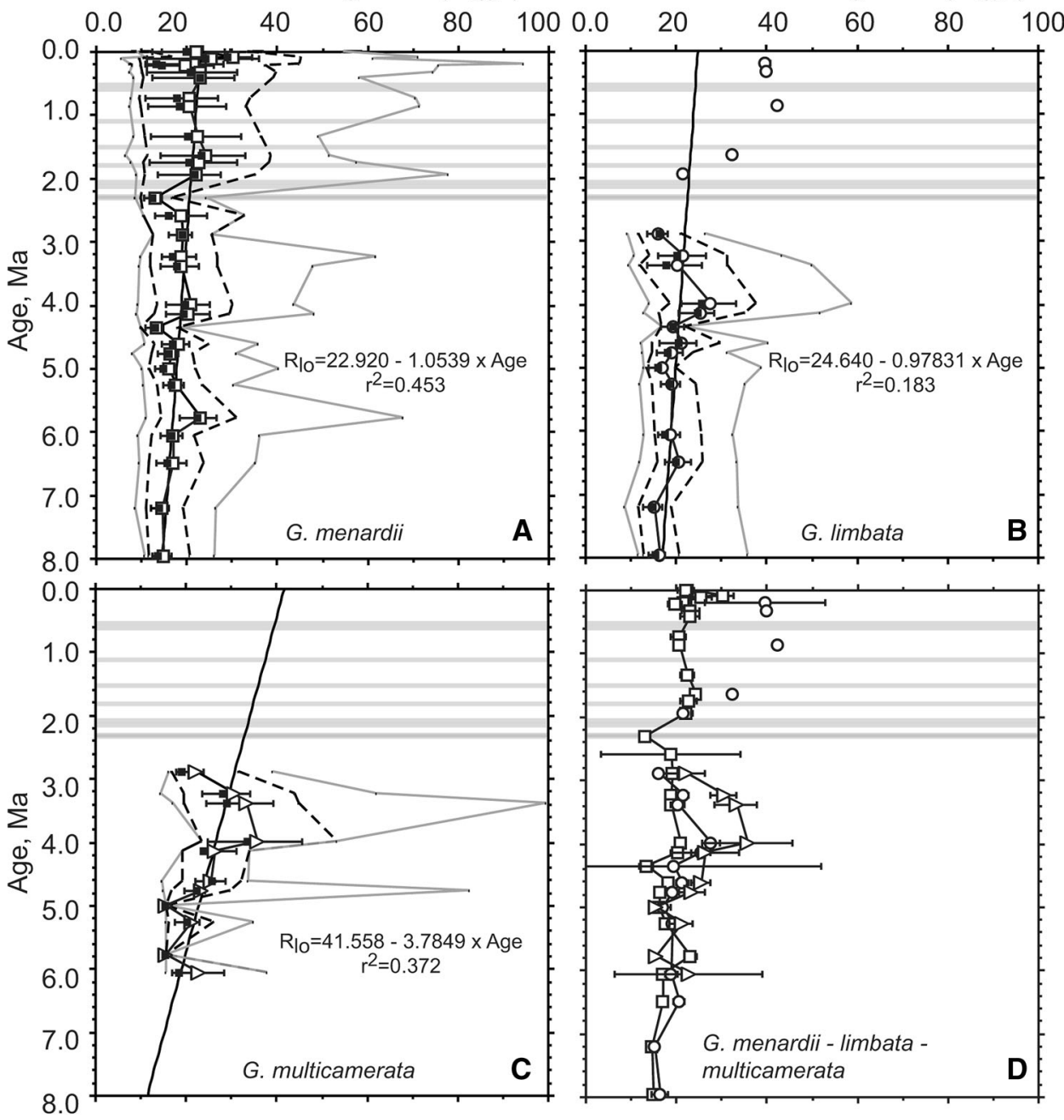

dramatic upper tail expansion of size in menardiforms after $2.3 \mathrm{Ma}$. A similar pattern was already noticed in the evolution of the cross-sectional area in Fig. 5. The increasing bimodality in frequency plots of spiral height versus axial length thus shows much better than the plots of mean size in Fig. 5, that the observed increase in mean cross-sectional size is no coherent reaction of the community. Instead, it is created by the appearance of a new group of distinctly larger morphotypes of $G$. menardii, while the smaller subset remained at its initial size. This is confirmed by the observation that positions of these secondary modes remain quite constant in the $\delta X$ versus $\delta Y$ plane in samples younger than $2.3 \mathrm{Ma}$. As will be discussed in the sections to follow, the sudden appearance of these larger tests of $G$. menardii in the ancient plankton has important consequences for paleoceanographic interpretations.

With respect to a suspected Middle to Late Pleistocene separation of $G$. menardii cultrata from $G$. menardii menardii after about $0.22 \mathrm{Ma}$ (Knappertsbusch 2007) no evidence can be seen for such a speciation event at Hole 925B. The inserted oblique thin lines in Fig. 12 separating $G$. menardii menardii (below the line) from $G$. menardii cultrata (above the line) since $0.22 \mathrm{Ma}$ at DSDP Site 502 (see Knappertsbusch 2007), continue passing through the modal centers at ODP Hole 925B.

\section{Contoured diagrams of spiral height $(\delta X)$ versus axial length $(\delta Y)$ for $G$. limbata}

Globorotalia limbata is discussed in the literature as an intermediate form between $G$. menardii and G. multicamerata. In the present contour diagrams of spiral height $(\delta X)$ versus axial length $(\delta Y) G$. limbata strongly overlaps with $G$. menardii. However, frequency modes of $G$. limbata tend to be at slightly larger values of $\delta X$ and $\delta Y$ in comparison to $G$. menardii (compare grayed contour lines with the solid black contour lines in Fig. 13). The only way to separate $G$. limbata from $G$. menardii is the number of 
Fig. 9 Plots of the mean ratio of spiral convexity (a) to umbilical convexity (b) per sample through time (in Ma) at Hole 925B for G. menardii (a), G. limbata (b), and $G$. multicamerata (c). Same explanation for symbols as in Fig. 5. For explanation of spiral convexity A and umbilical convexity B measurements refer to Fig. 4. Note the change in scale in $\mathbf{d}$ in order to highlight intermediate positions of mean convexity ratios of $G$. limbata (filled circles) at intervals when G. multicamerata showed strongest divergence. Data and statistics can be read from Tables $4 \mathrm{a}-\mathrm{c}$ and $5 \mathrm{a}-\mathrm{c}$ in the electronic supplementary materials

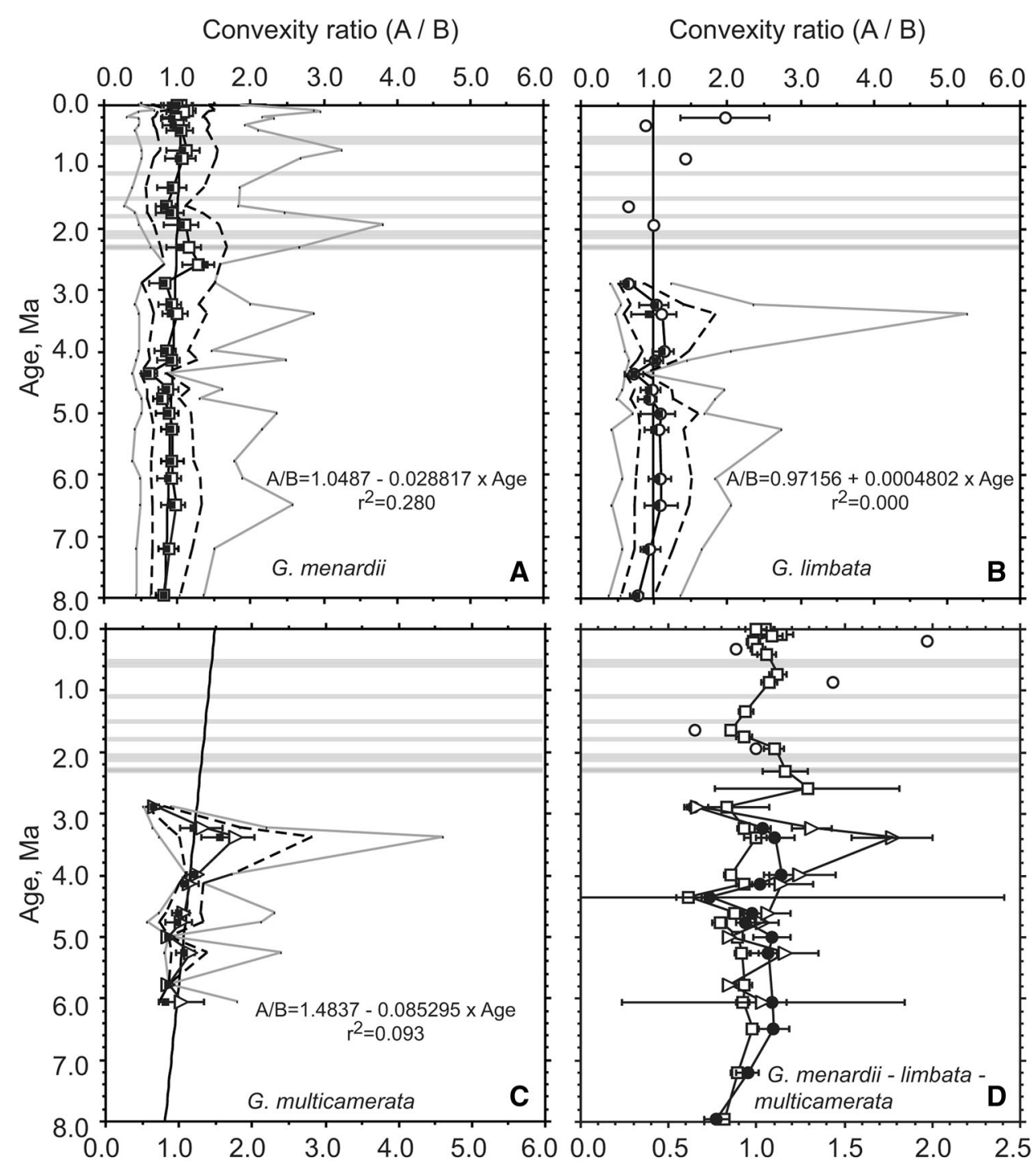

seven chambers in the final whorl in adults of the former. Sometimes, G. limbata shows a faint trend to finer wall perforation giving its test surface a shiny luster under incident light. It is undisputed, however, that the chamber number is a rather difficult method to differentiate between species, especially because it is applicable only to adults. It cannot be excluded that ontogenetic growth of $G$. limbata produced homeomorphic forms with less than seven chambers in the final whorl. If this turns out to be true in future $G$. limbata would totally resemble ancestral $G$. menardii, leaving the two species at least partially cryptic.

This difficulty requires the other morphological parameters, such as the above presented keel view area, convexity measures, osculating circles, or lower keel angles, to be considered as well for a better differential diagnosis. The comparison of these data shows, that on average $G$. limbata is intermediate between $G$. menardii and $G$. multicamerata with respect to keel-view area (Fig. 5), spiral convexity (Fig. 7), the radii of osculating circles of the lower keel region (Fig. 8), and the lower keel angle $\Phi_{2}$ (Fig. 11). However, these nuances are rather subtle and only recordable by careful comparison of ontogenetically mature populations from one time level to the next. In the pre-adult portion of the size spectrum a reliable distinction of $G$. limbata from $G$. menardii remains virtually impossible by morphological observations alone.

\section{Contoured diagrams of spiral height $(\delta X)$ versus axial length $(\delta Y)$ for $G$. multicamerata}

In the present study $G$. multicamerata was diagnosed as lenticular, biconvex, quasi-symmetric forms in keel view with 8 or more chambers in the final whorl. This is a pragmatic distinction and turned out to be useful in 
Fig. 10 Variation of the mean keel angle in the upper keel region $\left(\Phi_{1}\right.$, in degrees) through time (in Ma) at Hole 925B for G. menardii (a), G. limbata (b), and $G$. multicamerata (c). In d means of $\Phi_{1}$ are plotted together for better comparison (with $\pm 95 \%$ confidence intervals). Refer to Fig. 4 for explanation of parameters. For explanation of symbols see

Fig. 5. Data and statistics can be read from Tables $4 a-c$ and $6 a-c$ in the electronic supplementary materials

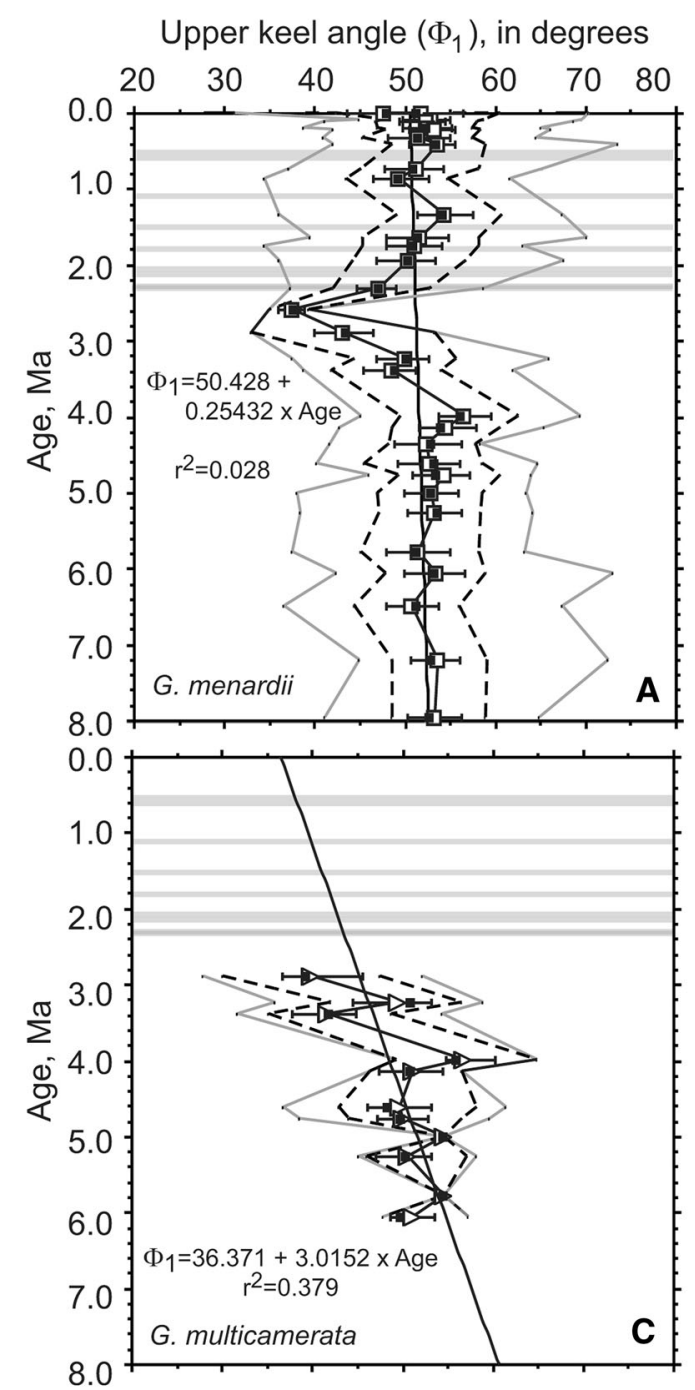

Upper keel angle $\left(\Phi_{1}\right)$, in degrees
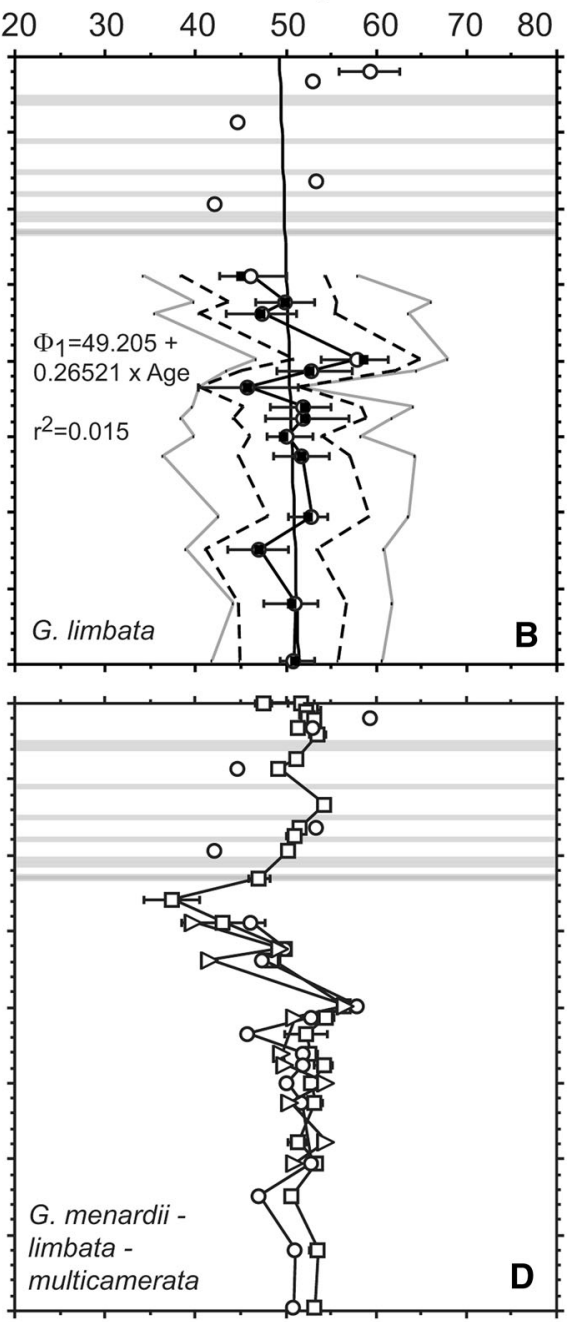

practice. With this criterion G. multicamerata is also identifiable in the $\delta X$ versus $\delta Y$ contour diagrams as a group that separated from small G. menardii or G. limbata from about $6.07 \mathrm{Ma}$ onwards. From then on, G. multicamerata increased its test size at Hole 925B until it became extinct between 2.88 and $2.59 \mathrm{Ma}$ (Fig. 14). Although some $\delta X$ versus $\delta Y$ contour diagrams for $G$. multicamerata contained only small specimen numbers they exhibit a tendency to expand test sizes with time. This is similar to G. menardii and G. limbata with the exception that the frequency modes of G. multicamerata overlapped more often with the upper tail of the distribution of contemporaneous G. menardii (compare solid black contour lines with grayed contour lines in Fig. 14).

In summary, the temporal trends of spiral height, axial length, keel view area, spiral convexity, radii of osculating circles in the lower keel region, and the upper keel angle are considered here a hint for a splitting event somewhere between the samples at 6.49 and $6.07 \mathrm{Ma}$ and for divergence of G. multicamerata from the ancestral G. menardii-G. limbata plexus surely post $5 \mathrm{Ma}$. Morphological cladogenesis in this group has been qualitatively described in the literature for some time (Kennett and Srinivasan 1983; Bolli and Saunders 1985; Aze et al. 2011), but was never quantified by morphometric measurements.

\section{Volume density diagrams for ODP hole 925B}

Variability of G. menardii-limbata-multicamerata tests through time is ideally illustrated by volume density diagrams. These are continuous, interpolated representations of stacked frequency distributions (specimen densities) of measurements through time. In Knappertsbusch and Mary (2012) volume density diagrams proved useful to illustrate evolutionary tendencies of menardiform globorotalids at DSDP Sites 502 and 503 and to visualize morphological 
Fig. 11 Variation of the mean keel angle in the lower keel region $\left(\Phi_{2}\right.$, in degrees) through time (in Ma) at Hole 925B for G. menardii (a), G. limbata (b), and $G$. multicamerata (c). In d means of $\Phi_{2}$ are plotted together for better comparison (with $\pm 95 \%$ confidence intervals). Refer to Fig. 4 for explanation of parameters. For explanation of symbols see

Fig. 5. Data and statistics can be read from Tables a-c and $6 a-c$ in the electronic supplementary materials

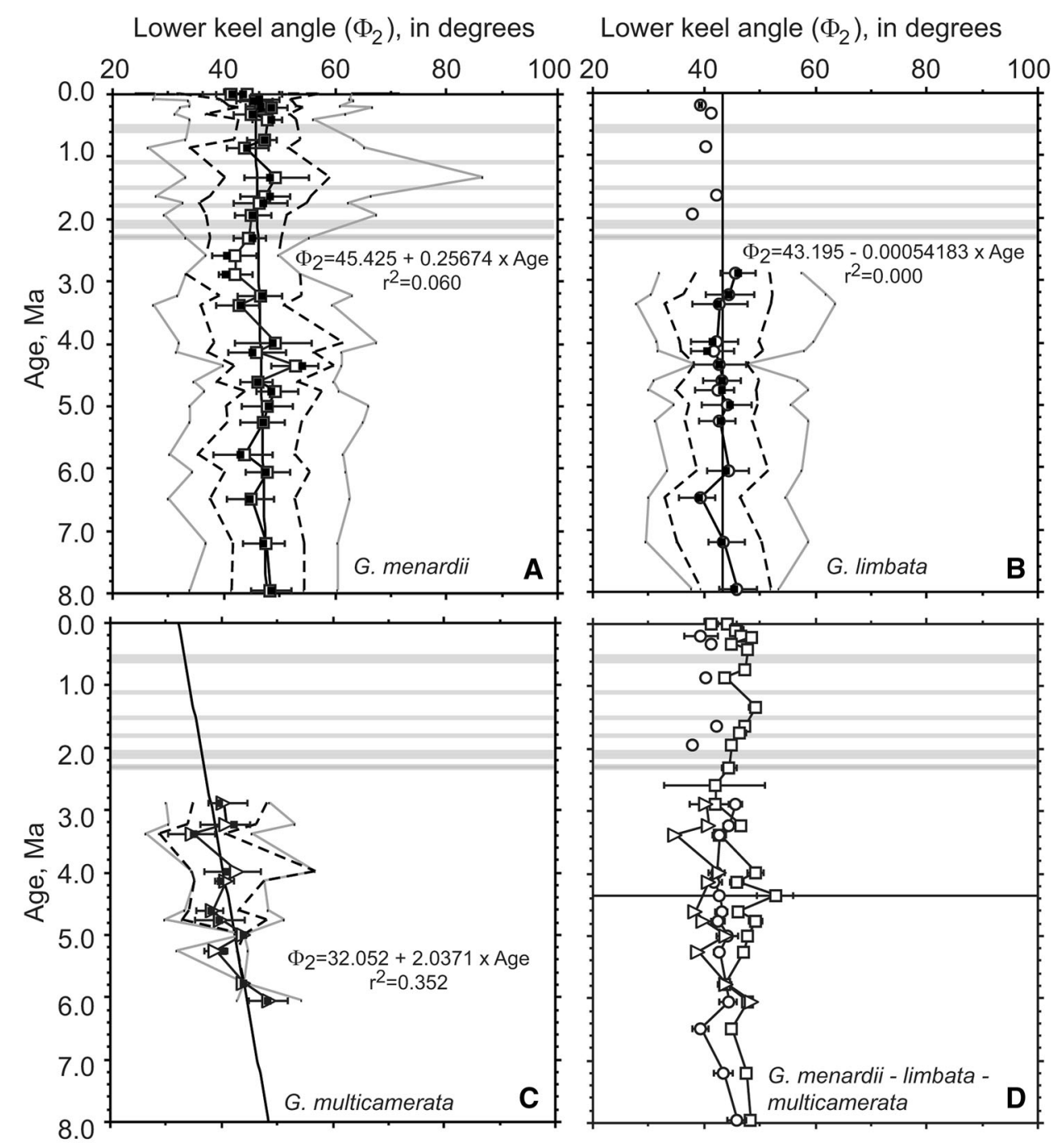

cladogenesis in the coccolithophore Calcidiscus leptoporus. The same method is applied in the present study to the bivariate set of spiral height $(\delta X)$ and axial length $(\delta Y)$, but it may be expanded to more than two variables as well. In the series of bivariate $\delta X$ versus $\delta Y$ measurements through time the specimen frequency of a particular grid cell (dimension $\Delta X$ by $\Delta Y$, see "Materials and methods" section) is encoded as a four-dimensional value called voxel. The value of a voxel represents the local specimen frequency in the bivariate morphospace spanned by $\delta X$ and $\delta Y$ per unit volume. The unit volume (unit cube) is spanned by two increments ( $\Delta X$ and $\Delta Y$ along the $\delta X$ and $\delta Y$ axes) and a third increment of time, which is normal to the plane of $\delta X$ versus $\delta Y$. When watched in a $3-\mathrm{D}$ coordinate system this four-dimensional ( $\delta X, \delta Y$, Time, Frequency) hypervolume shows up as involved isosurfaces (see the explanations in Figs. 13 and 14 of Knappertsbusch and Mary 2012). Each iso-surface represents a constant specimen frequency through time. Surfaces with high iso-values represent abundant specimens. They embrace the modal centers in the plane contour diagrams of $\delta X$ versus $\delta Y$ illustrated in Figs. 12, 13 and 14. The contour lines of modal centers connect from one time level to the next forming the "inner core" of the distribution. Low iso-values connect all outermost contour lines from one time level to the next. They indicate rare specimens and form the outermost "skin" of the four-dimensional hypervolume. The volume density surfaces must not be read in a false manner: It is the sudden appearance of large but rare specimens that make up the difference between post 2.3-1.95 Ma assemblages in comparison to earlier assemblages. Because new trends (caused by innovation or by immigration) are expected to begin at low amplitudes, an arbitrary but low iso-value of 0.4665 was chosen for the normalized frequencies for $G$. menardii, G. limbata and G. multicamerata. A similar value was selected in the illustrations of Knappertsbusch and 
Fig. 12 Contoured frequency plots of spiral height $(\delta X)$ versus axial length $(\delta Y)$ for $G$. menardii in keel view at Hole 925B from 0 to $7.96 \mathrm{Ma}$. The contour intervals (int) are in specimens per grid cell as indicated in the upper right corner of each diagram. The $n$ indicates the number of specimens represented in each diagram. The diagonal line in each diagram was suggested in Knappertsbusch (2007) to distinguish between morphotype alpha and morphotype beta in sediments younger than about $0.22 \mathrm{Ma}$. In that study morphotype alpha was tentatively associated with $G$. menardii menardii and morphotype beta with $G$. menardii cultrata including $G$. fimbriata. The same separation line is redrawn here for comparison reasons. Vertical gray auxiliary lines at $\delta X=300 \mu \mathrm{m}$ help to compare the secondary frequency modes between samples. The grid cell size is $\Delta \delta X=50 \mu \mathrm{m}$ and $\Delta \delta Y=100 \mu \mathrm{m}$. Measurements of $\delta X$ and $\delta Y$ from individuals can be read from Table $4 \mathrm{a}$ in the electronic supplementary materials
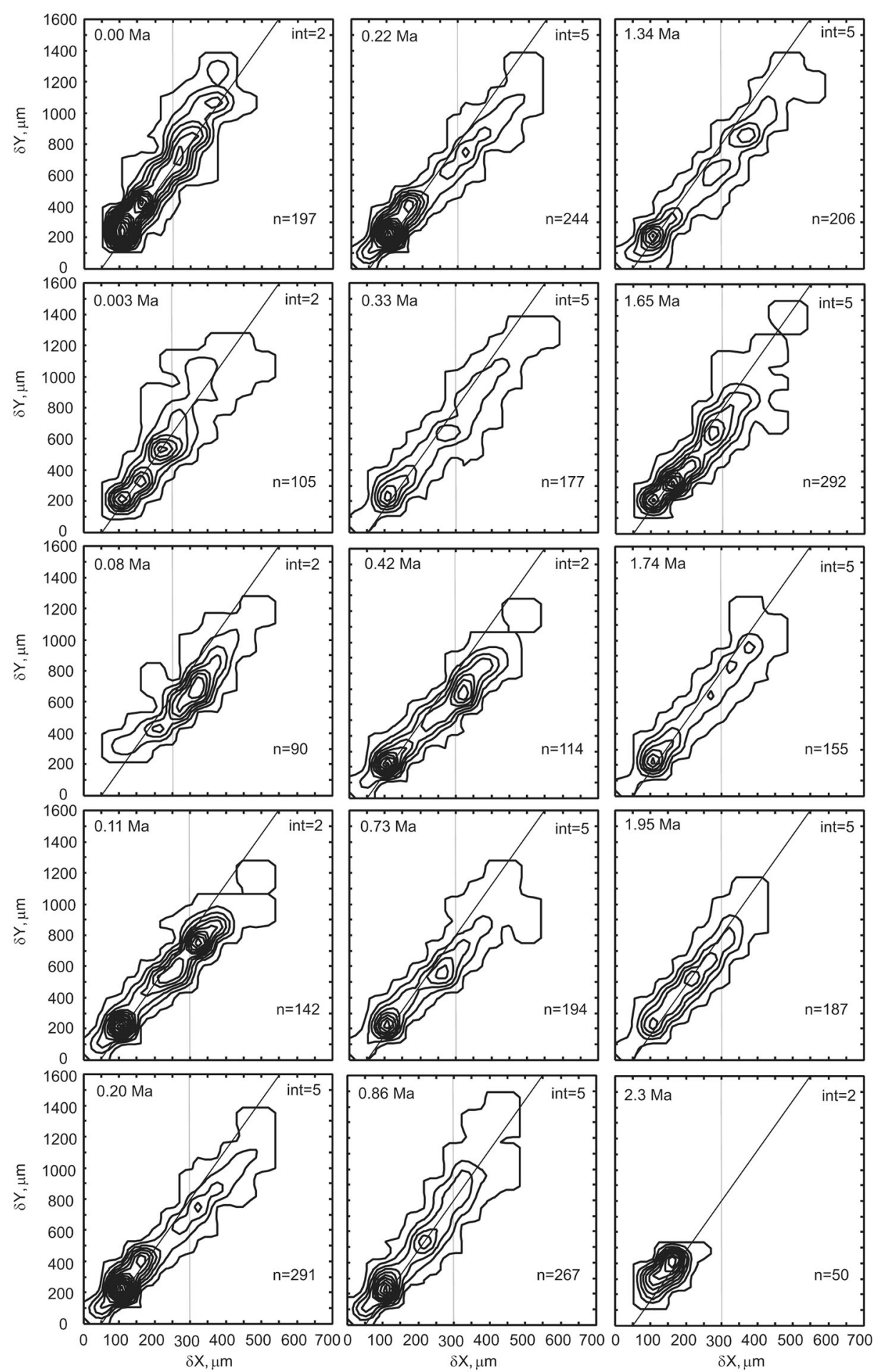

Mary (2013) for DSDP Sites 502 and 503, which makes those diagrams comparable to those from Hole 925B.

Specialization and adaptation causes species and their phenotypes to populate only certain areas of all possible combinations of morphological traits in its multi-dimensional Q-space (Q-space after Mitteroecker and Huttegger 2009). According to Shoval et al. (2012) species and phenotypes become enclosed by a multidimensional front called Pareto front. The volume density diagrams presented here may be considered a two-dimensional subset of such a Pareto front through time.

The expectation from constructing such volume density diagrams is that specific frequency modes from one time level to the next interconnect to branching clusters when 

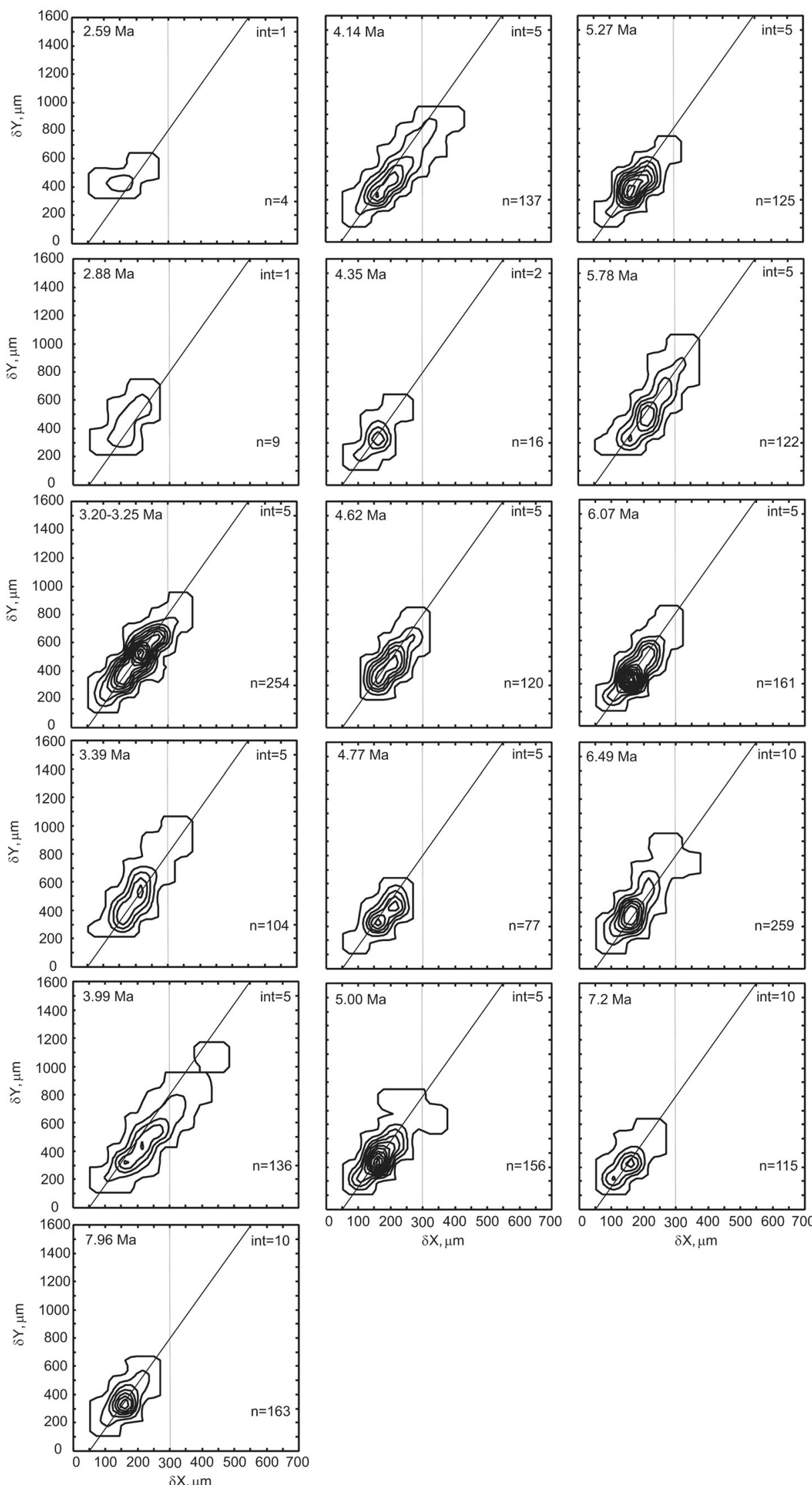

$0 \quad 100200300400500600700 \quad$ O 100200300400500600700

Fig. 12 continued $\delta \mathrm{X}, \mu \mathrm{m}$ 
Fig. 13 Contoured frequency plots of spiral height $(\delta X)$ versus axial length $(\delta Y)$ for $G$. limbata (solid black lines) in keel view from 0 to $7.96 \mathrm{Ma}$ at Hole 925B. Gray contour diagrams are those of G. menardii (identical to those shown in Fig. 12) for comparison reasons. Gray vertical lines at $\delta X=300 \mu \mathrm{m}$ are for easier comparison of modal centers. For explanations see caption of Fig. 12. Measurements of $\delta X$ and $\delta Y$ from individuals can be read from Table $4 b$ in the electronic supplementary materials
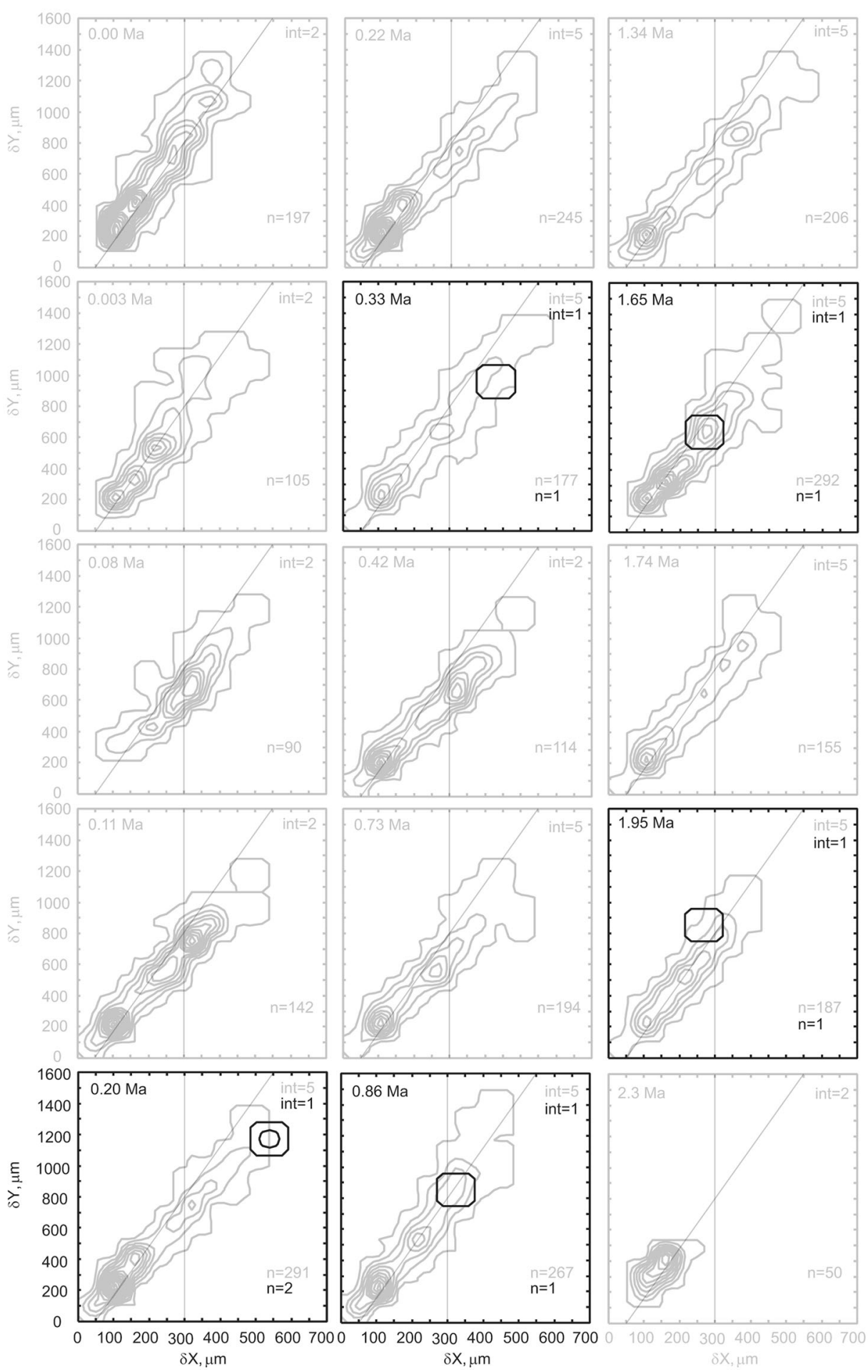

interpolated through time, which would help to check for presence or absence of morphological splitting at Site 925 in the G. menardii-limbata-multicamerata lineage. Similar ideas have been held by micropaleontologists for long time (see for example Fig. 1 in Hottinger 1962), but only the graphical capabilities of modern computers allowed for construction of such visualizations from quantitative data sets.
Volume density diagrams for G. menardii, G. limbata and $G$. multicamerata at ODP hole 925B

In Fig. 15 side views and front views of a low-frequency isosurface (isovalue $=0.4665$ ) for $G$. menardii, $G$. limbata and G. multicamerata are illustrated. In Fig. 15a-c the perspective is parallel to the axis of maximum size variation 
Fig. 13 continued
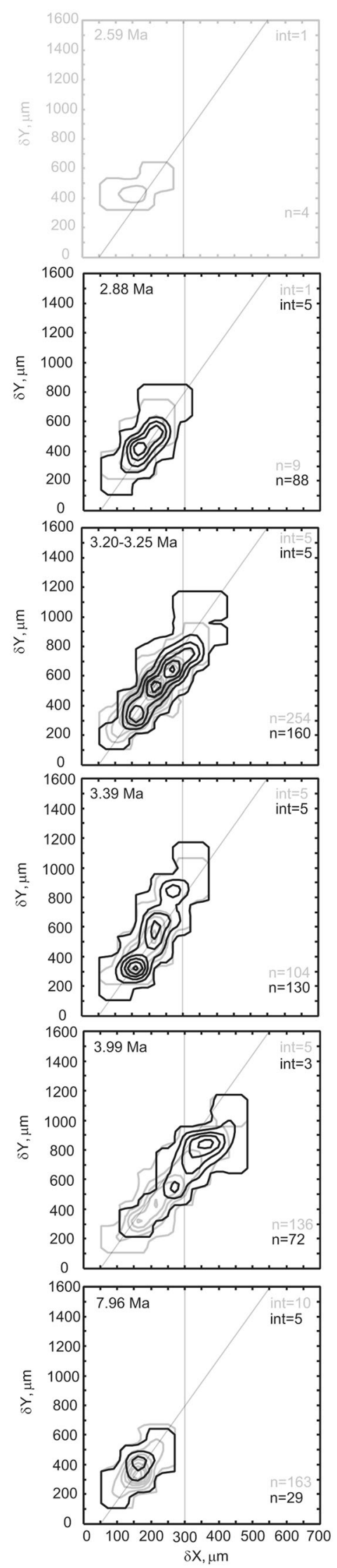
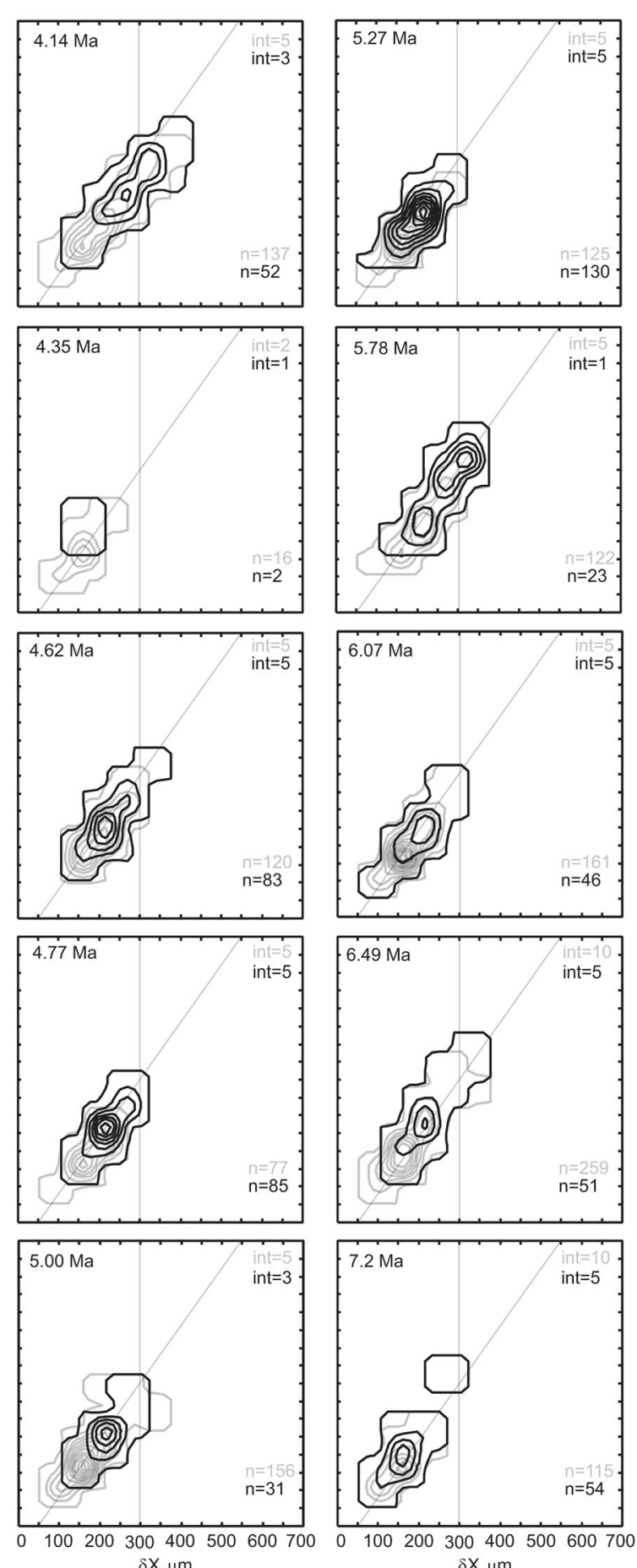

$\delta \mathrm{X}, \mu \mathrm{m}$ 
Fig. 14 Contoured frequency plots of spiral height $(\delta X)$ versus axial length $(\delta Y)$ for $G$. multicamerata (solid black lines) in keel view from 2.59 Ma to $7.96 \mathrm{Ma}$ at Hole 925B. Gray contour diagrams are those of $G$. menardii (as shown in Fig. 12) for comparison reasons. Gray vertical lines at $\delta X=300 \mu \mathrm{m}$ are for easier comparison of modal centers. For more explanations see caption for Fig. 12. Measurements of $\delta X$ and $\delta Y$ from individuals can be taken from Table $4 \mathrm{c}$ in the electronic supplementary materials
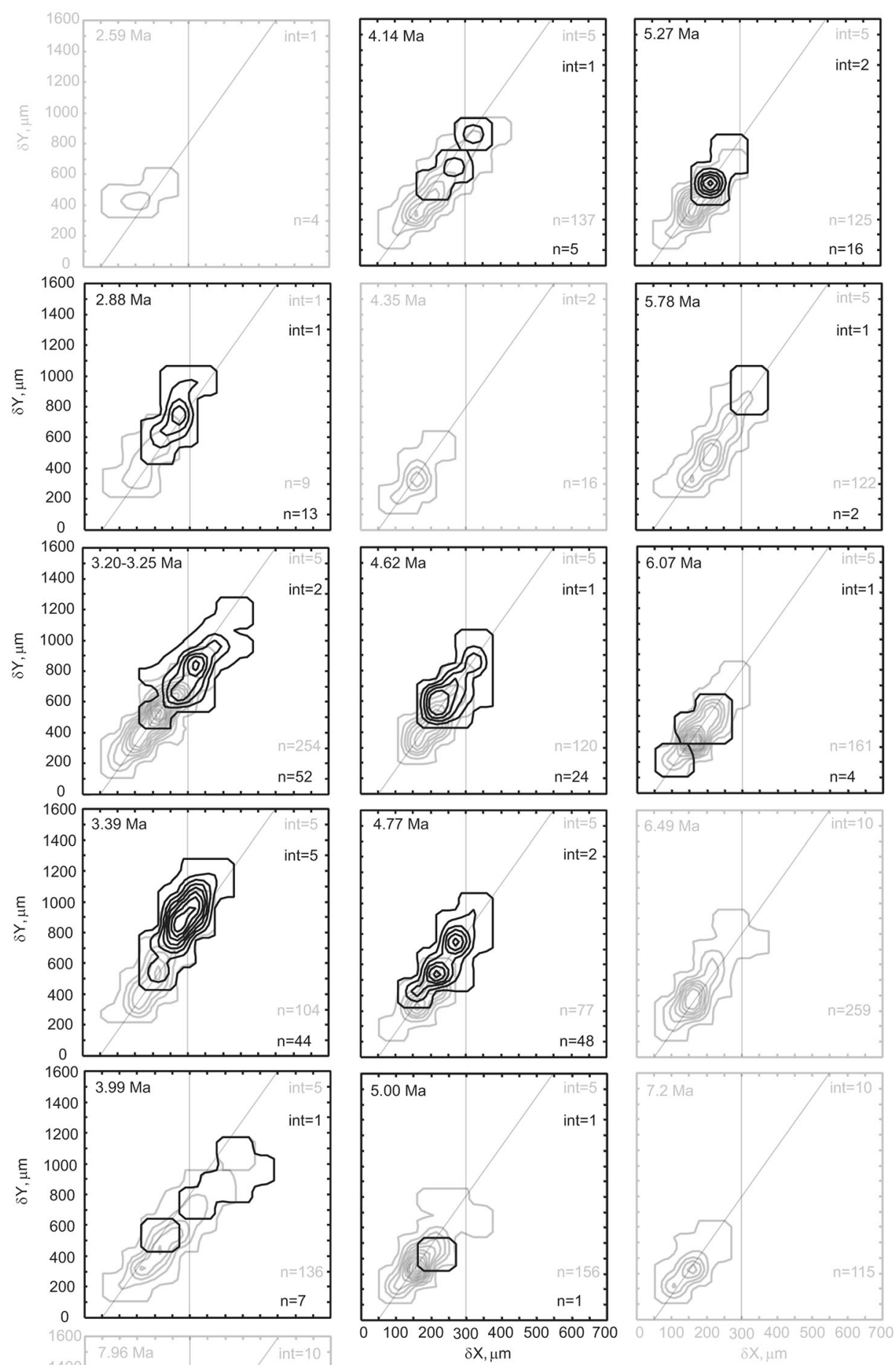
A

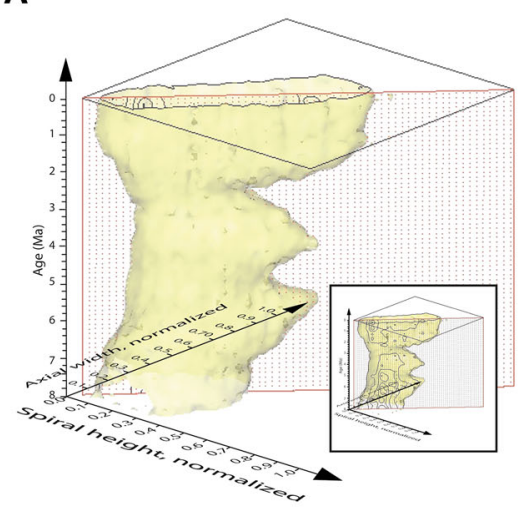

D

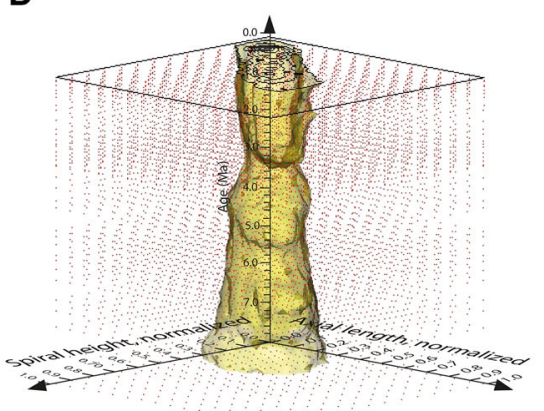

B

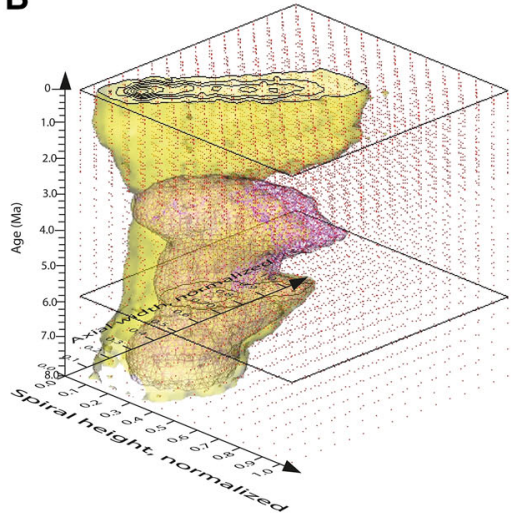

E

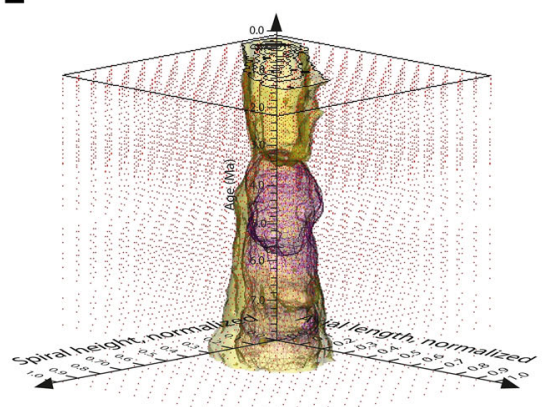

C

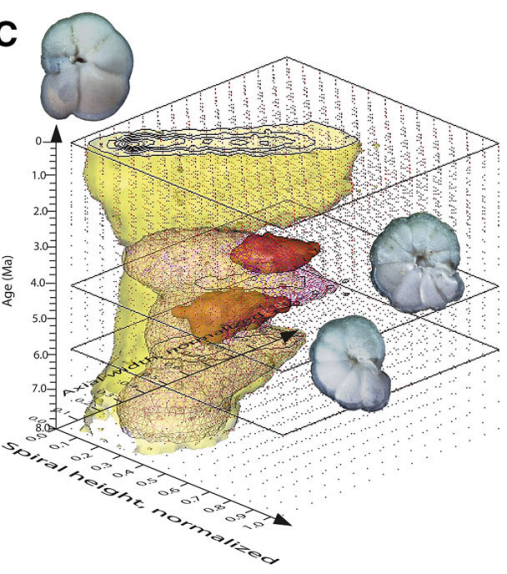

$\mathbf{F}$

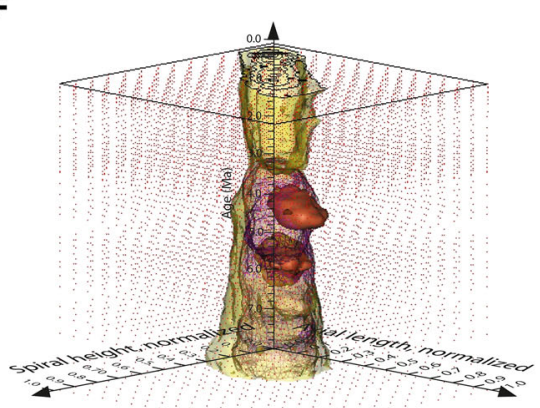

Fig. 15 Volume density diagrams of the variation of spiral height $(\delta X)$ versus axial length in keel view $(\delta Y)$ through time for $G$. menardii (yellow), G. limbata (purple, and G. multicamerata (red) at Hole 925B during the past 8 million years. Upper row shows diagrams in side view, lower row shows diagrams in front view. Axes of $\delta X$ and $\delta Y$ are scaled to values between 0 and 1 (see section about "Materials and methods" section). The time axis shows real ages (from 0 to $8 \mathrm{Ma}$ ) and were linearly converted from the $\Delta Z$ values in the original Voxler data set. All iso-surfaces represent an arbitrary but constant frequency value of 0.4665 (normalized $V_{i, j}$, see "Materials and methods" section). Settings for contour construction in Voxler 2: Method $=$ Min, Max, count; Min $=0.5, \operatorname{Max}=10$, interval $=1$. Red dots represent voxel centers after finer re-gridding was applied to the input data matrix. Superposition of the G. limbata iso-surface (purple in b,e) shows, that there is strong morphological overlap with G. menardii, which makes the two forms virtually indistinguishable by $\delta X$ and $\delta Y$ alone. Addition of the G. multicamerata iso-surface (red in $\mathbf{c}, \mathbf{f})$ shows two separate time-progressive surfaces suggesting

(which corresponds to the diagonal line in the $\delta X$ and $\delta Y$ plane passing through the origin and the point at coordinates $(1,1)$ (see section "Construction of volume density diagrams" in the methods section). In Fig. 15d-f the diagrams are rotated by $90^{\circ}$ to show the minimum size variation. Yellow iso-surfaces represent G. menardii, purple iso-surfaces are G. limbata, and red iso-surfaces represent G. multicamerata. Between $8 \mathrm{Ma}$ $(\Delta Z=-1)$ until $2.5 \mathrm{Ma}(\Delta Z=-0.31)$ the $G$. menardii isosurface consists of a rather slim lower body. This lower portion shows two intervals with size expansion at $5.78 \mathrm{Ma}$ $(\Delta Z=-0.72)$ and at $3.99 \mathrm{Ma}(\Delta Z=-0.5)$ corresponding to similar peaks seen for example in the curve of maxima of keel gradual size expansion and divergence of $G$. multicamerata from the ancestral G. menardii-G. limbata. The dotted plane in a represents a diagonal $\left(45^{\circ}\right)$ longitudinal section from 0 to $8 \mathrm{Ma}$ across the density volume, to which Fig. 16 is referred to for a paleoceanographic interpretation of the menardiform density pattern. In the small inset of a the upper cover of the iso-surface is removed to sketch the internal contoured density distribution of specimens through time in the longitudinal section (see Fig. 16 for an enlarged representation of contours in that projection). The data of scaled and normalized volume densities $V_{i j}$ of $G$. menardii, G. limbata and G. multicarmerat $a$ are available from Table $7 \mathrm{a}-\mathrm{f}$ in the electronic supplementary materials. Table $7 \mathrm{~g}$ of the electronic supplementary materials provides explanations to Table 7a-f. An animation of the volume density diagram shown in $\mathbf{c}$ is available from the electronic supplementary materials (file Supplmentary Video. Due to technical reasons the time-axis in this video is labeled with normalized ages instead of real ages)

view area in Fig. 5. At about 2.5 Ma the G. menardii isosurface is strongly constricted. Thereafter it expands dramatically in an upper body corresponding to the massive size expansion of $G$. menardii that is also reflected in the contour diagrams between 2.3 and $1.95 \mathrm{Ma}$ (compare with Fig. 12). The data to generate these diagrams are listed in Table $7 \mathrm{a}-\mathrm{f}$ in the electronic supplementary materials. See also the video showing a rotating animation of Fig. $15 \mathrm{c}$ in the electronic supplementary material (file Supplmentary Video).

The evolution of $G$. limbata and G. multicamerata shows a tripartite pattern (see Fig. 15b, e and c, f, 


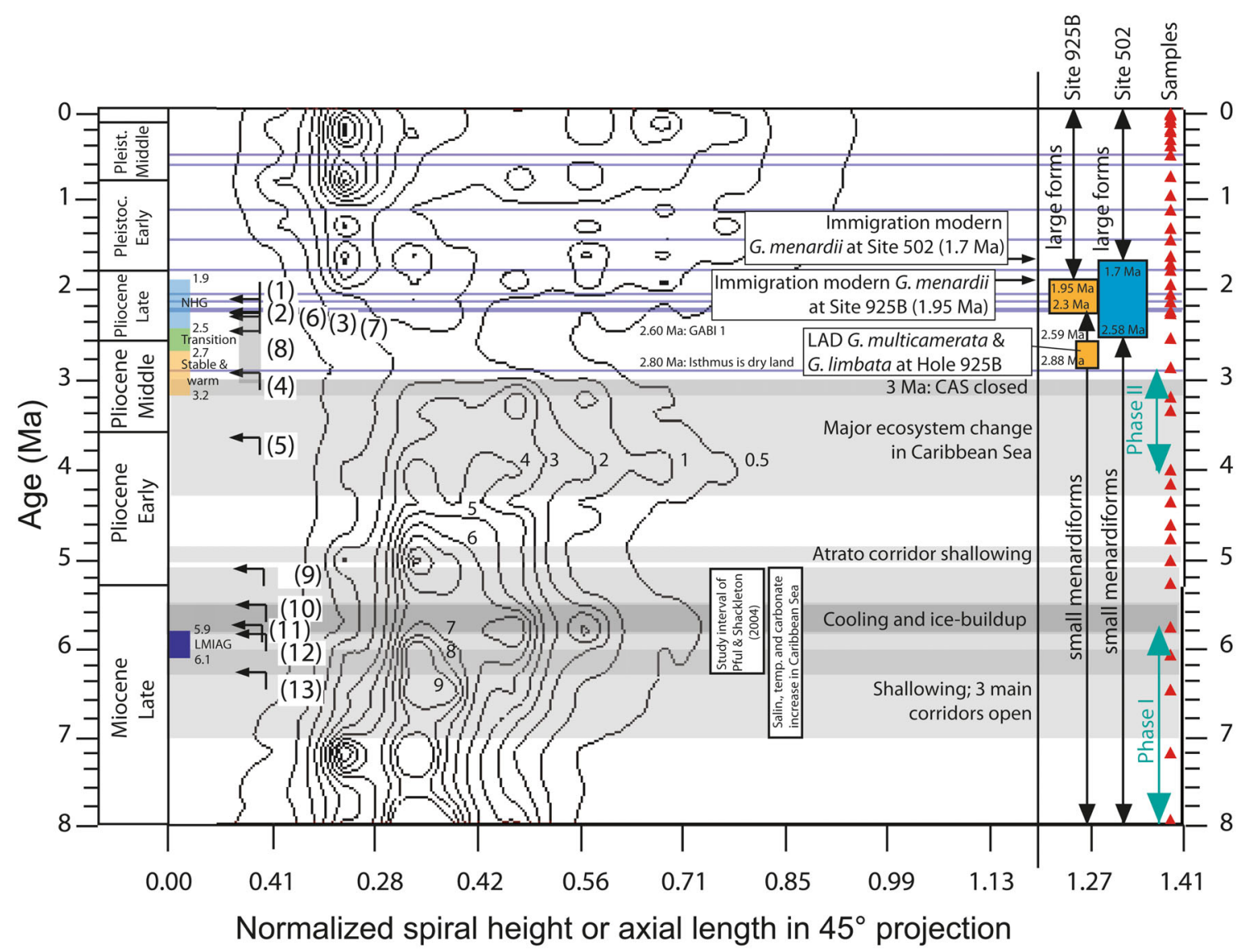

Fig. 16 The $45^{\circ}$ longitudinal section of contoured normalized frequencies of $G$. menardii from Hole 925B through time as illustrated in Fig. 15a but in paleoceanographic context. Contours (method: $\min , \max$, count; $\min =0.5, \max =10$, interval $=1$ ) indicate relative frequencies from 0 to 10 (contour intervals of 1 ). The base contour (0.5) corresponds approximately to the density isosurface shown in Fig. 15a. Because of the diagonal orientation of the longitudinal section the axes of spiral height and axial length collapse to one axis with values ranging from 0 to the square root of 2 . Red triangles on right side denote positions of the investigated samples at Hole 925B. Pale violet horizontal lines indicate G. menardii-barren intervals $(0.51,0.61,1.12,1.47,1.8,2.057,2.154,2.24,2.266$, and $2.91 \mathrm{Ma}$. The three G. menardii-barren intervals at $0.61,2.24$ and $2.91 \mathrm{Ma}$ are according to Chaisson and Pearson (1997). At $2.91 \mathrm{Ma}$ $G$. menardii was absent but $G$. miocenica and $G$. exilis were present (Chaisson and Pearson 1997). Colored rectangles on the right side of the diagram indicate important stratigraphic intervals discussed in the text for the G. menardii-limbata-multicamerata succession at Hole 925B. Of these, the lower orange rectangle (2.59-2.88 Ma) represents the interval when $G$. multicamerata and G. limbata disappeared at this hole. The orange rectangle higher up (2.3-1.95 Ma) indicates absence of large $G$. menardii at Hole 925B. The blue rectangle (2.58-1.7 Ma) indicates absence of large G. menardii at Site 502. First large G. menardii entered Site $925 \mathrm{~B}$ at $1.95 \mathrm{Ma}$, while at Site 502 first large G. menardii entered the sedimentary column at $1.7 \mathrm{Ma}$, i.e. about $0.25 \mathrm{Myrs}$ later. The colored rectangles on the left side of the diagram indicate paleoclimatic changes, such as the intensification of Late Miocene Antarctic Glaciation (LMAG in dark violet, between 6.3 and 5.9 Ma according to Chaisson and Ravelo 1997), and transition phases from stable warm conditions to intense Northern Hemisphere Glaciation (NHG) (after Chapman 2000). Black horizontal arrows labeled from 1 to 8 in parentheses indicate selected foraminiferal first appearance datum (FAD) and last appearance datum (LAD) events in relation to the history of the NHG: Events 1-6 are from Chapman (2000), event 7 is from Sexton and Norris (2008), and event 8 is from Chaisson (2003). Event $1=$ FAD G. menardii (2.13 Ma); event $2=$ LAD G. exilis (2.28 Ma); event $3=$ LAD $G$. miocenica (2.34 Ma); event 4=LAD G. limbata (2.93); event $5=$ disappearance Pulleniatina $(3.65 \mathrm{Ma})$; event $6=$ re-appearance Pulleniatina (2.3 Ma); event $7=G$. truncatulinoides immigration pulse (MIS 100, $2.54 \mathrm{Ma})$; and event 8 (gray vertical stripe $)=$ interval when finely perforated menardiforms tended to populate a deeper (cooler) water column (3.01-2.33 Ma). The darkened gray stripe between 6.34 and $5.1 \mathrm{Ma}$ and labeled from 9 to 13 (labels in parentheses) demarcates the study interval of Pfuhl and Shackleton (2004) at Site 925, when G. limbata and G. multicamerata diverged for the first time (phase 1): 9 Top of study interval (5.1 Ma); 10 end of cooling (5.49 Ma); 11 replacement of dominance of $G$. limbata by dominance of $G$. multicamerata $(5.75 \mathrm{Ma}) ; 12$ weakening of mixed layer, onset of cooling (5.82 Ma); and 13 base of study interval of Pfuhl and Shackleton (2004) (6.34 Ma). Green arrows on the right side indicate phases I (7.96-5.78 Ma) and II (4.14-2.88 Ma) of $G$. limbata development at Hole 925B (see text) 
respectively; compare also with contour diagrams in Figs. 13 and 14). From 7.96 to $5.78 \mathrm{Ma}$ G. limbata gradually increased its largest tests for the first time, similar to the curve of mean keel view area in Fig. 5b. Thereafter and until $4.62 \mathrm{Ma}$ the G. limbata population was frequent but became smaller in size, while at $4.35 \mathrm{Ma}$ it nearly disappeared from the record. From 4.14 Ma onwards, G. limbata markedly increased its size for a second time until $2.88 \mathrm{Ma}$, when it became extinct. After 2.88 Ma forms that look similar to G. limbata were sporadically observed as single specimens until 0.2 Ma.

The evolution of $G$. multicamerata shows a similar pattern: At 6.07 Ma the first representatives were small but separated from the G. limbata stock. Until 4.62 Ma $G$. multicamerata grew in size and so further diverged from $G$. limbata. At 4.35 Ma G. multicamerata was absent from the record, similar to G. limbata. Thereafter (4.14-2.88 Ma) G. multicamerata experienced a second phase of size increase and divergence, leading to specimens that look so typical like G. multicamerata, until it became extinct at 2.88 Ma.

\section{Paleoceanographic preconditions for the morphological evolution of menardiform globorotalids}

A brief paleoceanographic review in the framework of the emergence of the Isthmus of Panama and the PliocenePleistocene northern hemisphere cooling and its influence on menardiform biogeography is appropriate at this place prior to the discussion of the above results.

\section{The role of the Isthmus of Panama}

The closure history of the Central American Seaway was protracted over a long time span, was very complex (Leigh et al. 2013), and led to profound ecosystem and oceanographic contrasts on each side of the landbridge today. Prior to $3.2 \mathrm{Ma}$ (mid-Pliocene) climatic conditions were comparably stable and generally warmer than today (Pagani et al. 2010; Steph et al. 2006; Ravelo et al. 2006; von der Heydt and Dijkstra 2011; Lutz 2011; Haywood et al. 2007; Dowsett 2007; Chandler et al. 2008; LaRiviere et al. 2012; Brigham-Grette et al. 2013; O'Brien et al. 2014), but see also the more controversial picture drawn in Fedorov et al. (2013) and Steph et al. (2010).

The rise of the Isthmus of Panama had a pronounced influence on the heat transfer between the Pacific and the Atlantic Ocean, its currents, ecosystem development and Atlantic-Pacific faunal exchanges (Keigwin 1978, 1982; Kaneps 1979; Duque-Caro 1990; Coates et al. 1992). Surface water exchange between Atlantic and eastern
Equatorial Pacific became restricted since at least $4 \mathrm{Ma}$ (Haug et al. 2001). Panamanian Isthmus emergence is widely accepted to have completed by about $3 \mathrm{Ma}$ (Chaisson and Ravelo 1997; Cronin and Dowsett 1996; Molnar 2008; Jagadeeshan and O'Dea 2012; O'Dea et al. 2012), broadly supported by paleoceanographic data, biogeography and divergence of marine organisms, and terrestrial mammal biogeography, interchange and dispersal (Jackson and O'Dea 2013; Leigh et al. 2013; Marshall et al. 1979, 1982, 1988). Yet, there is still controversy on terminal closure (Knappertsbusch 2007; Stone 2013; Bacon et al. 2015). Some authors speculated about final oceanic isolation to some 10 Myrs earlier (Jackson and O'Dea 2013), while others assumed the persistence of a last narrow, shallow sea connection with restricted throughflow until about 2 Ma (Ibaraki 2002).

\section{Influence of global cooling and ice ages}

Roughly parallel with the closure of the Central American Seaway, climate conditions were relatively warm and stable from 3.2 until $2.7 \mathrm{Ma}$, followed by a transitional cooling phase until 2.5 Ma (Chapman 2000; Woodard et al. 2014). In the interval from 2.5 to 1.9 Ma major ice sheets began to expand on the northern hemisphere (Northern Hemisphere Glaciation, NHG), with establishment of pronounced climatic cyclicity thereafter (Tiedemann et al. 1994; Chaisson and Ravelo 1997; Chapman et al. 1998; Chapman 2000; Haug et al. 2001; Chaisson 2003; Steph et al. 2006; Pagani et al. 2010; Brigham-Grette et al. 2013). According to Mudelsee and Raymo (2005) cooling began even as early as $3.6 \mathrm{Ma}$. These climatic deteriorations and the associated complex hydrological changes are well sensed in form of thermocline deepening in the high northern to mid-latitude North Atlantic, while in the tropical west Pacific changes were manifested in form of thermocline shallowing (LaRiviere et al. 2012). But also in the western tropical Atlantic ODP Site 925 a continuous decline of thermocline dwelling foraminifera and a southward shift of the Intertropical Convergence Zone (ITCZ) from 4.71 Ma to latest Pleistocene indicated profound climatic deteriorations (Chaisson and Pearson 1997; Chaisson and Ravelo 1997).

\section{Development of an Atlantic-Pacific asymmetry as an efficient oceanic barrier through concerted tectonic activity and cooling}

The combination of tectonic movements and climatic changes strongly modified the oceanic heat exchange, which led to the development of the Pacific-Atlantic salinity and temperature contrast during and after the onset 
of the Northern Hemisphere Glaciation (NHG). The history and patterns are, however, complex and regionally different: In the eastern Pacific the system evolved from a dominantly warm water environment to one characterized by the modern cold tongue in the south and a warm pool to the north (Steph et al. 2010). At the same time, a warm water pool developed in the Caribbean Sea (Steph et al. 2010). During the Miocene there was a west to east net transport of watermasses (Von der Heydt and Dijkstra 2005). Experiments with coupled atmosphere-ocean models simulating an open Central American Seaway resulted in a similar transport of tropical water masses from the Pacific into the Atlantic Ocean (Klocker et al. 2005). However, Pliocene reconstructions demonstrated a deepened thermocline in the eastern Pacific (Von der Heidt and Dijkstra 2011). This may have led to an efficient temperature barrier through a still open but restricted Strait of Panama and so prevented migration of planktic warm water faunas from the tropical Pacific into the Caribbean surface waters.

\section{Menardiform biogeography}

Following Kennett and Srinivasan (1983) menardiform globorotalids evolved during the Middle Miocene from the G. praescitula-G. archeomenardii-G. praemenardii lineage. Knappertsbusch (2007) documented the size increase beginning from small menardiforms from the Late Miocene onwards in an eastern Equatorial Pacific and a Caribbean core. Traditionally, the evolution and biogeography of Pliocene menardiforms are interpreted to reflect changes in tropical circulation caused by the emergence of the Central American Isthmus and the intensification of the NHG (Keigwin 1982; Chaisson 2003). After 4.6 Ma, uplift of the Central American Landbridge created a distinct biogeography of menardiform globorotalids, ending in an endemic Atlantic population of finely perforated forms including G. exilis, G. pertenuis and G. miocenica, and a pan-tropical population with normal perforation including G. menardii, G. limbata and G. multicamerata (Keigwin 1982; Chaisson 2003). The finely perforated forms appeared and persisted only in the Atlantic part of the newly subdivided ancestral range of G. menardii, showing a vicariant distribution (Chaisson 2003). Atlantic endemism of these species was also observed by earlier workers (Stainforth et al. 1975; Kennett and Srinivasan 1983). A variant of $G$. multicamerata was also observed to be endemic for the Atlantic by Mary (2013) at 3.2 Ma. The normally perforated ancestor and still extant $G$. menardii and its extinct descendent plexus G. limbata-G. multicamerata are cosmopolitans. During the mid-Pliocene, when cooling began (Keigwin 1982) and permanent Northern Hemisphere ice sheets started to grow from about
3.2 Ma onwards (Shackleton and Opdyke 1977), the majority of menardiforms became extinct. Only the normally perforated, ancestral population of G. menardii survived (Chaisson 2003).

\section{Discussion}

\section{Long distance immigration as alternative to explain the sudden Late Pliocene size increase of $G$. menardii at Hole 925B ?}

Particularly between 2.58 and $1.7 \mathrm{Ma}$, G. menardii became severely reduced in abundance and existed only in small forms. At DSDP Site 502, this interval extends from 2.58 to $1.7 \mathrm{Ma}$ (Knappertsbusch 2007). At Site 925 singular menardiform-barren intervals occurred already at $2.91 \mathrm{Ma}$ although $G$. miocenica and $G$. exilis were present at that time (compare with range chart given in Chaisson and Pearson 1997). G. menardii-barren intervals were especially frequent in the time span from 2.3 to $1.95 \mathrm{Ma}$ (see Fig. 16). Thereafter, G. menardii experienced a rapid and prominent increase especially in the upper extremes of the test sizes (see Figs. 5, 12, 15, 16). In the younger than 1.9 Ma part at Hole 925B menardiform-barren intervals still occurred, but not as often as between 2.3 and $1.95 \mathrm{Ma}$. Synchronous glacial/interglacial changes of presence/absence and size variations of $G$. menardii during the Quaternary were reported by Ericson and Wollin (1956a, b, 1968), Sexton and Norris (2011), Bhonsale and Saraswat (2012) and Da Costa Portilho-Ramos et al. (2014). The sudden and distinct increase in the upper tail of the size distributions of G. menardii during the end of the Pliocene is striking. In the opinion of the author, this rather suggests an immigration event of large forms than rapid morphological evolution.

Repeated seeding of G. menardii and other tropical planktic foraminiferal species after longer periods of absence in the Atlantic is discussed in context of faunal repopulation events through the ancient Central American Seaway (Saito 1976; Keigwin 1982; Kennett and Srinivasan 1983; Bolli and Saunders 1985). However, repeated faunal immigration into the Atlantic is also known via the "Cape Valve" around the Cape of Good Hope (Berger and Vincent 1986; Berger and Wefer 1996; Chapman 2000; Giraudeau et al. 2002; Zahn et al. 2012). Already Schott (1935) observed the widespread absence of G. menardii in glacial sediments and their re-invasion during glacialpostglacial transitions, which Berger (2013) interpreted in light of Indian-Atlantic exchange via the Agulhas System. For considerable time after World War 2 the role of the Agulhas system became neglected or even nearly forgotten (Lutjeharms and Kortum 2005). In recent years, 
paleoceanographic interest in the Agulhas Current has been reinvigorated, including its sensitivity to climate change (Zahn et al. 2012; Hall et al. 2015).

The re-immigration of various planktic foraminiferal species into the Atlantic after the onset of NHG (Keigwin 1982; Chaisson 2003) is highly remarkable. For example, after an extended period of absence, re-immigration and coiling changes of Pulleniatina occurred during the Late Pliocene at 2.3 Ma (Saito 1976; Kaneps 1979; Keigwin 1982; Bolli and Saunders 1985; Curry et al. 1995).

\section{Discussion of size change of G. menardii at Hole 925B in the perspective of the Agulhas migration hypothesis}

The G. menardii-G. limbata complex comprised predominantly forms with small to intermediate sized tests between 8 to about 3 Ma. Figures 13, 15b and 16 suggest that at Site 925 this early complex developed in two phases, i.e., G. limbata phase I (from 7.96 to $5.78 \mathrm{Ma}$ ), and $G$. limbata phase II (from 4.14 to $2.88 \mathrm{Ma}$ ). At $4.35 \mathrm{Ma} G$. limbata almost completely disappeared. Both branches of G. limbata ended in G. multicamerata, the first ranging from 6.07 to $4.62 \mathrm{Ma}$ and the second from 4.14 to $2.88 \mathrm{Ma}$. Whether this repetitive pattern indicates that early $G$. multicamerata simply disappeared from the Atlantic for a while and then was re-introduced during the Early Pliocene cannot be answered at this moment and needs further investigation. Alternative scenarios are ecophenotypic changes due to directional selection or repeated speciation and iterative evolution. Each of the three mentioned possibilities would imply a different biological process. At this place, it is interesting to note that a similar first phase, when the G. limbata-G. multicamerata plexus separated from G. menardii, was also identified by Pfuhl and Shackleton (2004) at the same location. Based on stable isotope analyses these authors interpreted the replacement of $G$. limbata by $G$. multicamerata and the development of the latter as a response to changes from a deep to a shallow mixed layer. The second phase of the $G$. limbata-G. multicamerata differentiation (4.14-2.88 Ma) matches with the study interval of Chaisson (2003). It possibly also represents a morphological adaption of $G$. menardii or G. limbata to shallower levels. Between 2.88 (sample 925B-10-4, 126.5-127.5 cm) and 2.59 Ma (sample 925B-9-5, 92.5-93.5 cm), both G. multicamerata and G. limbata became extinct at Hole 925B. These extinction events were perhaps linked with a southward expansion of glacial excursions leading to changes in the local wind systems, sea surface temperatures and upper water column stratification. Such changes could have been linked to seasonal changes of the position of the ancient ITCZ. Migration of the ancient ITCZ have possibly caused a displacement of the North Brazil Current in a similar manner as during the Last Glacial Maximum (see "Discussion" to follow further below), but all these explanations require more investigation as well.

During the same time interval (i.e., samples at $2.88 \mathrm{Ma}$ and $2.59 \mathrm{Ma}$ ) G. menardii became extremely rare and small (compare contour diagrams in Fig. 12 with Figs. 15a and 16). Higher up in section at Hole 925B menardiformbarren intervals became more frequent during the late Pliocene until $2.057 \mathrm{Ma}$ (Fig. 16). In that interval of the core, the menardiform-depleted intervals overlap with the very cold periods of the NHG. According to Chapman (2000) these extremely cold periods lasted between about 2.5 and $1.9 \mathrm{Ma}$. They presumably led to profound changes in the wind regime (paleo trade winds) and the structure of the upper water column. At Site 925 G. menardii reappeared at $1.95 \mathrm{Ma}$ indicated by a sudden and massive increase in both abundance and test size (see Figs. 12, 16). It is interesting to note that also the tropical genus Pulleniatina, which disappeared at Hole 925B between 4.14 Ma (sample 925B-14-2, 51-52 cm) to $3.99 \mathrm{Ma}$ (sample 925B-13-5, 127-128 cm) for a long time period, re-entered the site with abundant specimens and almost simultaneously with the larger menardiforms around $1.95 \mathrm{Ma}$ (sample 925B-7-5, 71.5-72.5 cm). Also small $G$. tumida, a lower thermocline dweller (Ravelo and Fairbanks 1992), re-entered Hole 925B in low lumbers at $1.95 \mathrm{Ma}$ after a long period of absence (data not shown). In this context note Chaisson's (2003) report about re-introduction of this species in the Atlantic together with Globoquadrina hexagona and pulleniatinids, which are both excellent indicators for tropical marine environments (Bé et al. 1976; Bé and Tolderlund 1971). The re-appearance of these warm water species is interpreted here to indicate re-strengthening of the North Brazil Current and re-establishment of full tropical conditions after cooler intervals during the previous NHG at Site 925.

\section{Comparison of morphological trends at ODP Site 925 with those at DSDP Sites 502 (Caribbean Sea) and 503 (Eastern Equatorial Pacific)}

In Fig. 17, volume density diagrams are compared to each other for G. menardii at ODP Hole 925B (Ceara Rise), the Caribbean Sea DSDP Site 502 (Colombia Basin) and the eastern Equatorial Pacific DSDP Site 503 (Southern Guatemala Basin) during the past 8 myrs (all at iso-value of 0.4665). The data for the latter two sites were taken from Knappertsbusch (2007), and Knappertsbusch and Mary (2012), and were re-plotted here for comparison.

The similarity of menardiform size distributions between ODP Hole 925B and DSDP Site 502 is very striking. The beginning of the interval, where only rare and 


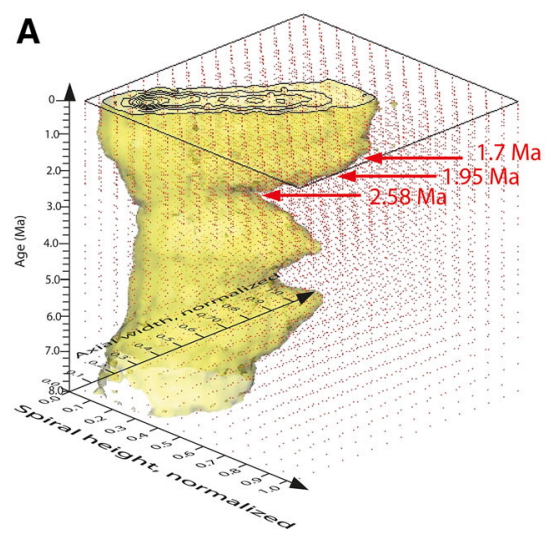

B

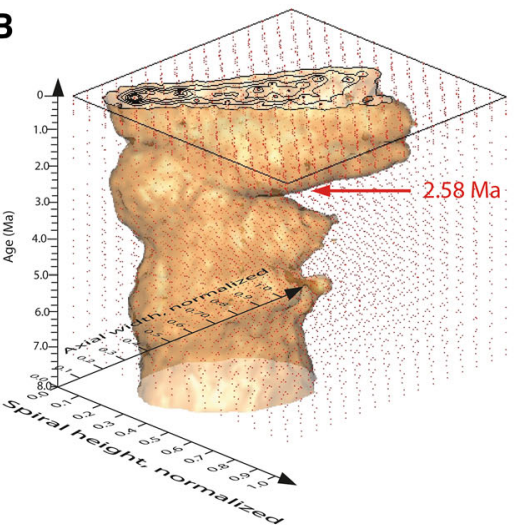

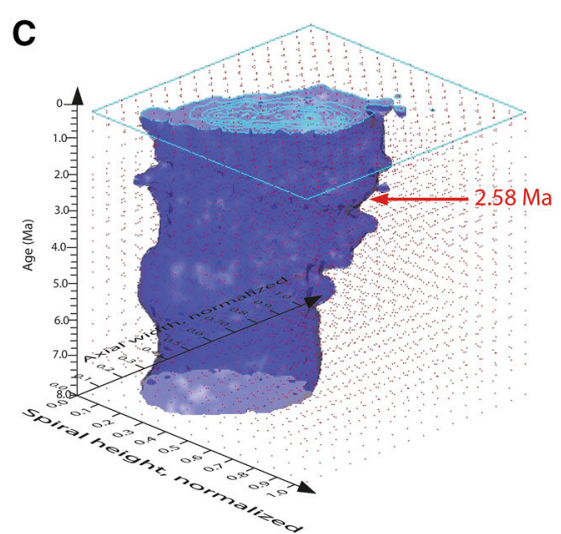

Fig. 17 Evolution of spiral height $(\delta X)$ versus axial length $(\delta Y)$ of $G$. menardii during the past $8 \mathrm{Ma}$ represented by volume density diagrams at a ODP Site 925B (Ceara Rise), b DSDP Site 502 (Caribbean Sea), and c DSDP Site 503 (eastern equatorial Pacific). Volume density diagrams are involved surfaces of equal specimen frequencies, where rare specimens populate outer surfaces and frequent specimens occur on more inner iso-surfaces. The illustrated iso-surface skins in $(\mathbf{a}-\mathbf{c})$ are hulls of the outer tails of skewed frequency distributions through time and thus represent rare forms. The red arrows at $2.58 \mathrm{Ma}$ denote the lower bound of the blue

small G. menardii prevailed at DSDP Site 502 (i.e., from 2.58 to $1.7 \mathrm{Ma}$, duration ca. $0.88 \mathrm{myr}$ ) precedes the beginning of the equivalent interval (i.e., from 2.3 to $1.95 \mathrm{Ma}$, duration $0.35 \mathrm{myr}$ ) at the more equatorward ODP Site 925 by about 280 kyrs (Figs. 16, 17). G. menardii becomes a relatively larger percentage of sedimentary assemblages when thermocline shoals in the photic zone (Leckie 1989; Chaisson and Ravelo 1997). The abovementioned different onset times and durations of $G$. menardii-depleted intervals between the two sites may be explained by a likely southward shift of the subtropical gyre, the associated NE trade winds, and the position of the Intertropical Convergence Zone (ITCZ) during glacial extremes. Such conditions occurred for example during the Last Glacial Maximum, when the glacial subtropical gyre moved by at least $10^{\circ}$ south (McIntyre 1967; Prell and Hays 1976). Due to stronger trade winds and increased evaporation southern Sargasso Sea type of water was produced in the Caribbean Sea leading to a deepening of the mixed layer and a depression of the thermocline in the Caribbean Sea at those extreme glacial intervals (Bé et al. 1976; Prell and Hays 1976; Chaisson and Ravelo 1997). As a result growth of the $G$. menardii plexus ceased leaving $G$. menardii-barren intervals behind in the underlying sediments, also in the Columbia Basin. The modern ITCZ migrates seasonally between $9^{\circ} \mathrm{N}$ in boreal summer and $2^{\circ}$ in boreal winter, causing tropical semihumid summers and more subtropical semiarid winters (Prell and Hays 1976; Schneider et al. 2014). During the Pleistocene the climatic system responded to millennial coolings in high northern rectangle shown in Fig. 16 (absence of large menardiforms at Site 502). The red arrow at $1.95 \mathrm{Ma}$ in a marks the beginning of immigration of extra-large adults at Site 925. The red arrow at 1.7 Ma indicates the entry of extra-large adults at Site 502 further north in the Caribbean Sea. On the Pacific side (c) the pattern is more continuous. Iso-values are set to 0.4665 . Contours in Voxler are set to Method $=$ Min, Max, count; Min =0.5, Max =10, interval =1). Data to draw the diagrams for DSDP Sites 502 (b) and 503 (c) were taken from Knappertsbusch (2007) and Knappertsbusch and Mary (2012)

latitudes by an increased southward migration of the ITCZ (Schneider et al. 2014; Prell and Hays 1976; Gardner and Hays 1976). At maximum glacial incursions trade winds intensified even more and the associated water column changes (i.e., duration and intensity of deepening of the seasonal thermocline layer) extended farther towards the geographic equator. This caused G. menardii-depleted sediments also over Ceara Rise, though with shorter duration and delayed with respect to the Caribbean Sea farther to the north. This scenario is in good accordance with the paleoceanographic model presented in Chaisson and Ravelo (1997).

While absence or fluctuations in abundance of $G$. menardii can be well explained by glacial-interglacial cycles, the rapid appearance of extra-large G. menardii past $1.95 \mathrm{Ma}$ at Site 925 and past $1.7 \mathrm{Ma}$ at Site 502 remains enigmatic. There is no similarly rapid change in upper-tail size distributions of $G$. menardii in that time interval at eastern equatorial Pacific DSDP Site 503, where the evolutionary trend of this species shows a more gradual pattern. This asymmetry suggests that menardiform populations between the tropical Pacific and the Caribbean or the tropical Atlantic were isolated from each other at that time. Locally, processes like the "founder-effect" and bet-hedging (the production of fewer and larger offspring when environments vary unpredictably) could in principle aid fast morphological adaptation and induce fast size increase. Such processes were for example observed to occur in fish egg sizes (Einum and Fleming 2004). Especially the "founder-effect" may have increased the pace of 
evolutionary adaptation of a small population, that just had survived a harsh glacial period also in the case of planktonic foraminifera. Such processes may help explain adaptive test size increase in G. menardii, but further research with living planktic foraminifera is clearly necessary on this item. Despite such possible explanations, the singular occurrence of such rapid change in upper size extremes at DSDP Sites 502 and 925 during the past 8 myrs and its absence in the equatorial Pacific suggest the involvement of different processes rather than only in situ adaptation on the Atlantic side. In this context, the Agulhas immigration hypothesis comes to mind as a plausible alternative mechanism. Following this hypothesis large $G$. menardii may have gradually developed extra-large forms in western Pacific isolation or in the Indian Ocean, which then invaded the Atlantic Ocean when warming intensified faunal leakage to the south Atlantic via the Agulhas Current. With this hypothesis the appearance of large $G$. menardii from southeast to west remains also in logical temporal order at Sites 925 and 502.

\section{Synthesis: changing mechanisms of menardiform size evolution at Hole 925B}

\section{Late Miocene to late Pliocene}

During the Late Miocene to Late Pliocene the evolutionary mode of G. menardii exhibits an uninterrupted, rather gradual and slow test size increase. This may represent the "normal" case of undisturbed, slow and ever increasing tendency toward larger cellular and test sizes. Such trends are often brought in relation with Cope's Rule (Stanley 1973; McKinney 1990; McShea 1994; Schmidt et al. 2006; Aze 2011), although the mechanisms for phyletic size increase are still poorly understood (Kingsolver and Pfennig 2004; Hone and Benton 2005). Test-size increase is quite often seen in foraminifera (Schaub 1963; Hottinger 1963; Parker et al. 1999; Schmidt et al. 2004; Aze 2011). Especially in larger benthic foraminifera accelerated (or prolonged) growth during ontogeny and evolution, and the associated increase of test size is known to reflect an environmental adaptation to maintain the carrying capacity over long periods of time. In larger benthic foraminifera such adaptations represent an extreme form of K-mode strategy of life (Hottinger 1982, 2000, 2001). In planktic foraminifera increase of test size reflects perhaps a similar tendency in survival strategy, albeit at a much lesser degree.

During the rise of the Isthmus of Panama, cladogenesis was triggered, though with comparably slow divergence, leading from ancestral $G$. menardii to the lineage of $G$. limbata-G. multicamerata (see Fig. 15). According to
Kennett and Srinivasan (1983), Chaisson (2003) and own observations from Site 925 (see raw data set in Knappertsbusch 2015b) a further menardiform clade, the $G$. exilis-G. pertenuis lineage, appeared during the Pliocene when stable and warm conditions prevailed. Both clades became extinct as Northern Hemisphere cooling progressed between 2.5 and $2.7 \mathrm{Ma}$. Unfavorable climatic or oceanographic conditions established for some longer time during the development of NHG (about 2.5-1.9 Ma), and even in the western tropical Atlantic surviving G. menardii remained small in size and populations.

\section{Post-pliocene}

One interesting outcome of this study is the contrasting post-Pliocene morphological evolution in G. menardii between the Eastern Equatorial Pacific and the AtlanticCaribbean. At the Pacific Site 503 (Guatemala Basin) selection favorably led to gradual size increase in $G$. menardii, whereas test size patterns of G. menardii at Hole 925B (Ceara Rise) and Site 502 (Caribbean Sea) were presumably superposed by distinct immigration pulses of G. menardii populations introducing large forms after 1.95 and $1.7 \mathrm{Ma}$, respectively. In the preceding study of Knappertsbusch (2007), the rapid size change of extremes during the prevailing continuous sedimentation regime was tentatively interpreted to reflect accelerated adaptive evolution during the Pliocene-Pleistocene. At that time changes of the upper water column structure and stratification became more accentuated as a response to the emergence of the Isthmus of Panama. With the here presented new observations this earlier explanation must perhaps be abandoned in favor of the alternative of post-Pliocene invasion of large G. menardii from the Indian Ocean or from the western Pacific area. Invasion would be due to faunal leakage into the southern to equatorial Atlantic via the Agulhas Current at intervals, when Indian Ocean water eddy transport to the south Atlantic was possibly intensified.

Long distance dispersal events are nothing special in Earth history, a fact that is increasingly acknowledged in more recent research. One of the most remarkable examples is the trans-oceanic crossing of monkeys and caviomorph rodents from the Old World to the New World during the Late Eocene and Late Oligocene (Leigh et al. 2013; Nathan and Nathan 2014). In order to strengthen the proposed paradigmatic change from vicariance biogeography to long distance dispersal in G. menardii, a few more paleoenvironmental arguments are brought forward.

During times of an open and unrestricted connection between the tropical Pacific and the Caribbean Sea, model simulations show a transport of tropical less saline water masses from the Pacific into the Atlantic (Klocker et al. 
2005; Mikolajewicz and Crowly 1997). The latter study points to a non-linear, hysteretic relationship between strength of North Atlantic convection and trans-isthmian water transport. During 4.3-3.6 Ma the ancient and prevailing warm eastern equatorial Pacific turned to the modern state showing a distinct surface water temperature gradient from eastern equatorial Pacific cold tongue and upwelling in the south (as for example at Site 1239 off Ecuador) to the East Pacific Warm Pool (EPWP) in the north (Steph et al. 2010). For Site 1241 (Guatemala Basin) $\mathrm{UK}{ }_{37}$ paleotemperature analyses indicate warm temperatures in the uppermost water column until at least $2.5 \mathrm{Ma}$ (Steph et al. 2010). At Caribbean ODP Sites 999 and 1000, $\delta^{18} \mathrm{O}$ and $\mathrm{Mg} / \mathrm{Ca}$ data show prevailing warm pool conditions from $4.3 \mathrm{Ma}$ until post $2.5 \mathrm{Ma}$ at the surface $(G$. sacculifer), while $\delta^{18} \mathrm{O}$ of thermocline dweller $N$. dutertrei indicates cooling of subsurface waters and deepening of the thermocline layer (Steph et al. 2010). At this point, we must keep in mind that there are discrepancies in Pliocene paleotemperature estimates between $\mathrm{Mg} / \mathrm{Ca}, \mathrm{UK}_{37}$ and $\mathrm{TEX}^{\mathrm{H}}{ }_{86}$ paleothermometry (O'Brien et al. 2014). Some model results suggest that in the equatorial Pacific depth changes of the $20^{\circ} \mathrm{C}$ isotherm is little affected by the closure of the Central American Seaway (see Fig. 3 in Steph et al. 2010), but general cooling during NHG is imprinted elsewhere (Wara et al., 2005; Lawrence et al., 2006), and for example in the tropical $\delta^{18} \mathrm{O}$ record of the Ontong Java Plateau in the western equatorial Pacific (Chaisson and Ravelo 1997; Shackleton and Opdyke 1977; Jansen et al. 1993). For times of maximum NHG ice sheet expansion it seems, thus reasonable to assume a similar cooling of subsurface waters within the geographic extend of modern EPWP. After 2.7 Ma and coeval with a major northern glacial pulse (MIS 110) and sea-level drop, the Panamanian isthmus was probably dry (Molnar 2008; Woodburne 2010; Leigh et al. 2013). At 2.6 Ma, the first main pulse of the terrestrial Great American Biotic Interchange (GABI 1) began, followed by further such phases indicating existence of a landbridge from 2.7 to 2.5 Ma onwards (Woodburne 2010; Leigh et al. 2013 and references cited therein).

Extant G. menardii is known to be most abundant in the tropical seasonal thermocline when that feature is within the photic zone and when a relatively strong nutricline is present (Fairbanks and Wiebe 1980; Chaisson and Ravelo 1997; Chaisson 2003). In addition, transitions between modes with and without North Atlantic Deep Water formation and the above-mentioned weakened trans-isthmian water exchange can be caused by external events, such as lowered sea level during glaciations (Mikolajewicz and Crowley 1997; electronic supplement in Miller et al. 2005). Such conditions occurred undoubtedly also at the end of MIS 110. Consequently, and even with a prevailing west to east surface current direction (see further above) through the terminal corridors connecting the equatorial Pacific with the Caribbean Sea, cool subsurface to thermocline temperatures shortly before final isthmus closure became probably unsurmountable for any trans-isthmian tropical thermocline dweller like G. menardii during the Late Pliocene cooling.

Following the paleogeographic and paleoclimatic reconstructions drawn in Woodburne (2010), Leigh et al. (2013), and Jackson and O'Dea (2013), a trans-isthmian exchange of menardiforms through the ancient Costa Rican to Colombian corridors after $2.5 \mathrm{Ma}$ is unlikely.

The remaining possibilities for G. menardii to re-populate the Atlantic-Caribbean after the Late Pliocene are either the idea of "deglacial proliferation" of menardiform survivors suggested by Sexton and Norris (2011), or repopulation events via Agulhas leakage of Indian Ocean surface waters around South Africa. The modern Agulhas Retroflection with its large warm core rings is known to be an efficient vehicle for entrainment of warm thermocline waters and its plankton contents from the Indian Ocean into the colder south Atlantic (Gordon 1985; Lutjeharms and Gordon 1987; Beal 2011). Such a mechanism has also operated during the Pleistocene (Berger and Vincent 1986; Berger and Wefer 1996; Flores et al. 1999; Giraudeau et al. 2002; Rau et al. 2002, 2006; Peeters et al. 2004; Caley et al. 2012; Zahn et al. 2012; Broecker and Pena 2014; Hall et al. 2015) especially during periods of deglaciation (Beal 2011; Marino and Zahn 2015). Long distance dispersal of Truncorotalia truncatulinoides was observed at ODP Sites 999 and 925 during MIS 100 at 2.54 Ma from a southwest Pacific source via the Indonesian throughflow and Agulhas Current into the South Atlantic 31 (Sexton and Norris 2008). It is certainly not unreasonable to assume a similar dispersal route for G. menardii although in that particular case no pulses of G. menardii were observed to occur together with the event of $G$. truncatulionides at Site 925 (personal communication with Philip Sexton 2013-2014).

Studying modern Globigerinella, another tropical planktic foraminifer, Weiner et al. (2014) questioned the importance of invaders carried with the Agulhas current because of failure to establish a viable population in competition with South Atlantic niche incumbents. Villar et al. (2015) pointed to the selective mechanisms inside Agulhas rings that may limit dispersal of Indian Ocean Plankton populations into the Atlantic. However, the southern biogeographic border of modern G. menardii around the South African cape area (Bé et al. 1966) cannot be denied. Episodes of intensified Agulhas transport during glacial/interglacial transitions may well have allowed populations to survive long enough for dispersal further north into the Atlantic under more favorable conditions than today. Such a dispersal mechanism may also explain the intermittent pulses of Pleistocene menardiforms at ODP 
Site 1087 described by Giraudeau et al. (2002) and Caley et al. (2012) to at least $1.35 \mathrm{Ma}$. In this context, the Agulhas migration hypothesis is a likely explanation for the repopulation events of $G$. menardii and other taxa in Hole 925B, which lies in the pathway of currents directed from the Agulhas leakage across the southern to equatorial
Atlantic (Beal 2011; Caley et al. 2012; Scussolini et al. 2013).

Under these conditions, it would also not surprise if the marked decline of Thalassiothrix mats (in the literature referred to as the Matuyama Opal Maximum, MOM) between 1.9 and 2.1 Ma at ODP Site 1084 off Lüderitz,
Fig. 18 Umbilical, spiral and profile views of menardiform globorotalidss investigated during this study. 1-3 G. menardii menardii, sample 925B-2-6, 37-38 cm, specimen 925026037aK1401. 4-6 G. menardii cultrata, sample 925B-2-3, 76-77 cm, specimen 925023076aK0201. 7-9 Giant form of $G$. menardii menardii from sample 925B-4-3, 74-75 cm, 925043075aK1601. 10-12: G. limbata from sample 925B-11-4, 66-67 cm, specimen $925114067 \mathrm{aK} 1501$. 13-15 G. multicamerata from sample 925B-12-1, 68-69 cm, 925121068cK1401. Specimens were imaged using a motorized Leica MZ6 binocular microscope, a JVC digital camera (model KY-F75U), a Planapo $1.0 \times$ objective, and using extended focus imaging with software AutoMontage Pro 5.03 from Syncroscopy (see also Knappertsbusch et al. 2006) for methods on enhanced imaging of microfossils under reflected light). 9 Imaged at the magnification position at $2.50 \times$ (long scale bar represents $500 \mu \mathrm{m})$. All other figures were imaged at the magnification position at $3.20 \times$ (short scale bars represent $100 \mu \mathrm{m}$ )
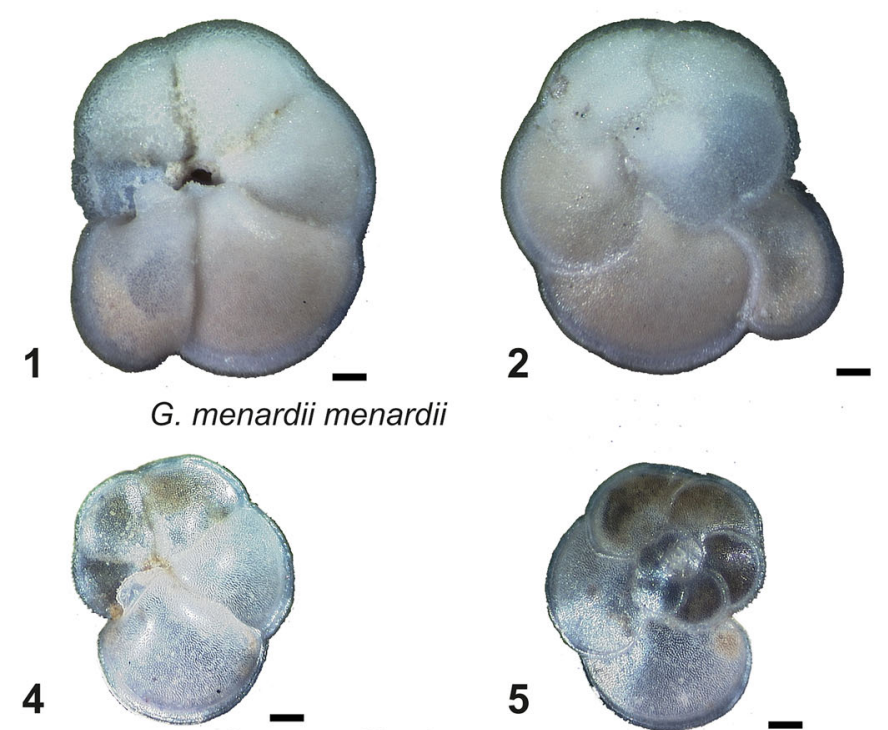

G. menardii cultrata
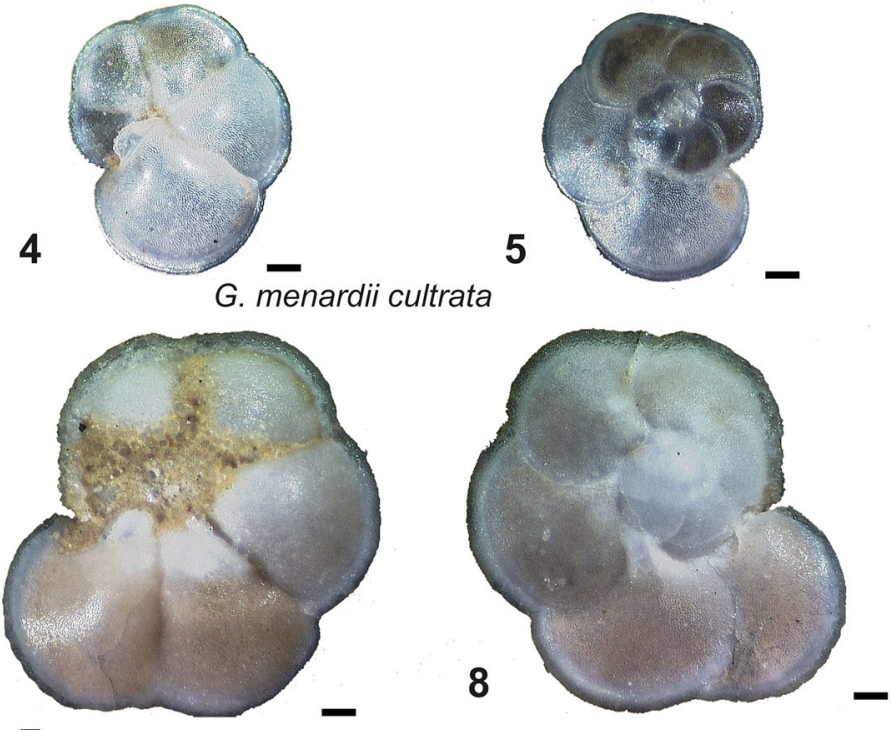

7

Giant G. menardii menardii

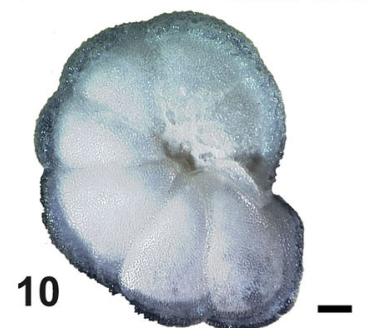

G. limbata

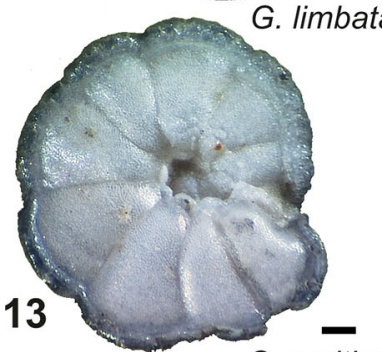

11

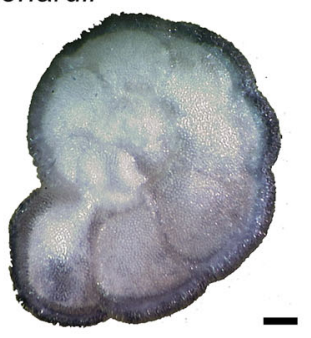

14

G. multicamerata
3

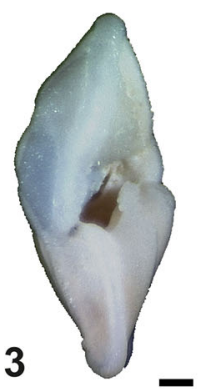

6

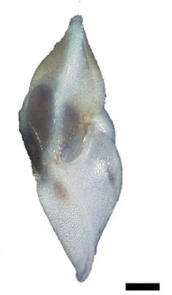

9

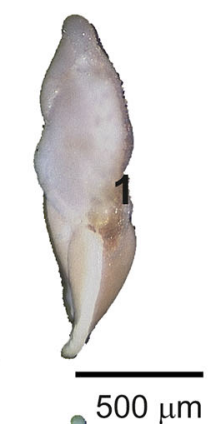

12

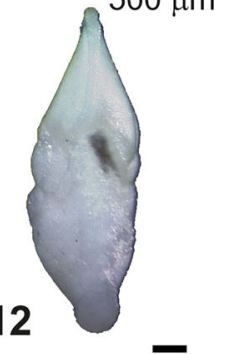

15

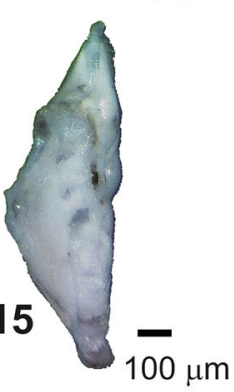


SW Africa (Marlow et al. 2000; Berger et al. 1998) stands in causal relationship with a supposed episode of intensified Agulhas leakage and menardiform dispersal from the Indian Ocean or the Pacific into the South Atlantic. The
MOM is hypothesized to mark a time when the Benguela Current was flowing less vigorously than today. A less active Agulhas Retroflection (with decreased eddy activity) allowed sporadic entrainment of Subantarctic waters into
Fig. 19 Umbilical, spiral and profile views of menardiform globorotalidss investigated during this study. 1-3 G. exilis, sample 925B-14-6,

$130-131 \mathrm{~cm}$, specimen 925146131aK2601. 4-6 G. pertenuis, sample 925B-10-4, $126.5-127.5 \mathrm{~cm}$, specimen 925104127aK0901. 7-9 G. miocenica from sample 925B$10-4,126.5-127.5 \mathrm{~cm}$, specimen $925104127 \mathrm{aK} 3101$. 10-12 Transitional form $G$. menardii-G. pseudomiocenica from sample 925B-23-4, 103-117 cm, specimen 925234103aK1601. 13-15

Large post-immigration $G$. menardii menardii from sample 925B-7-5, 71.5-72.5 cm, specimen 925075072aK1601. 16-18 Pre-immigration $G$. menardii menardii-G. exilis from sample 925B-8-6,

124-125 cm, specimen 925086125bK2801. For color imaging details of specimens see captions of Fig. 18. All figures were imaged at a magnification position at $3.20 \times$ (scale bars represent $100 \mu \mathrm{m}$ )

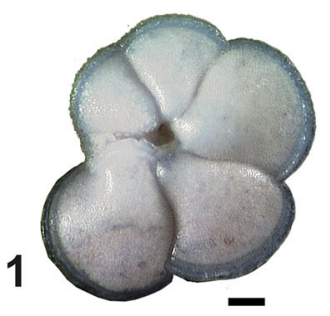

G. exilis

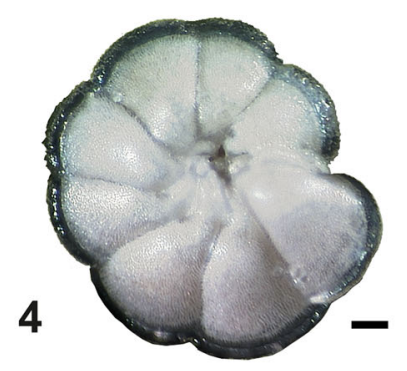

G. pertenuis

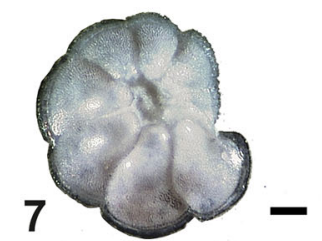

G. miocenica

10

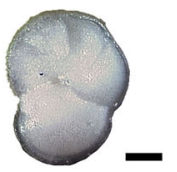

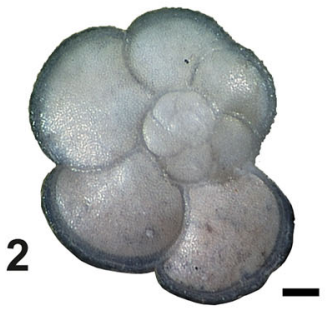

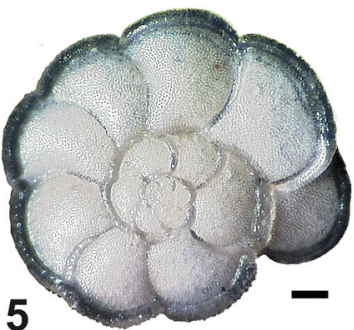

8

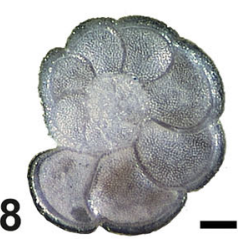

11

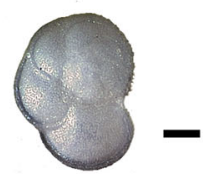

G. menardii - G. pseudomiocenica

13
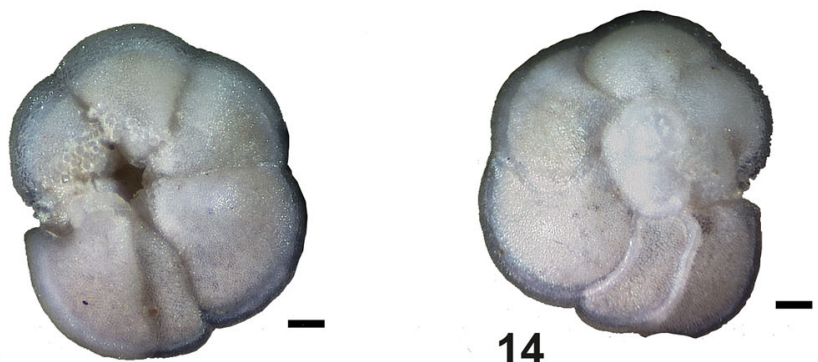

14

Post - immigration G. menardii
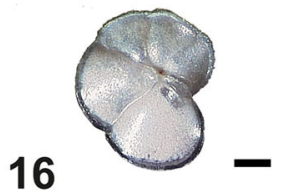

Pre - immigration G. menardii

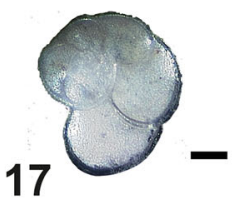

3

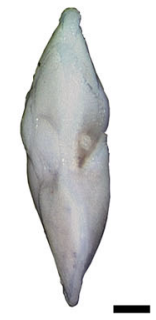

6

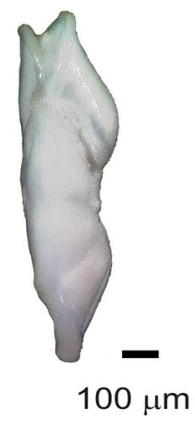

9

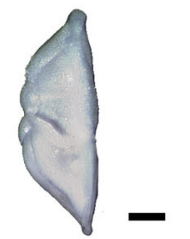

12

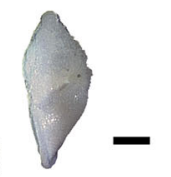

15

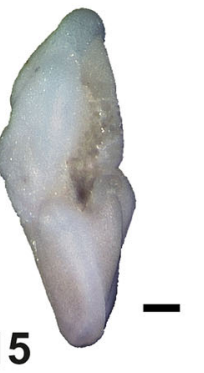

18

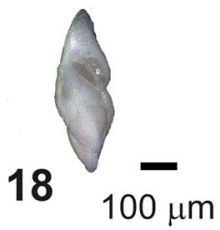


Fig. 20 Umbilical, spiral and profile views of menardiform globorotalids investigated during this study. 1-3 G. tumida tumida, sample 925B-1-1, $15-16 \mathrm{~cm}$, specimen 925011015bK2801. 4-6 G. tumida flexuosa, sample 925B$1-3,125-126 \mathrm{~cm}$, specimen $925013125 \mathrm{aK} 3601$. For color imaging details of specimens see captions of Fig. 18. All figures were imaged at a magnification position at $3.20 \times$ (scale bars represent $100 \mu \mathrm{m}$ )

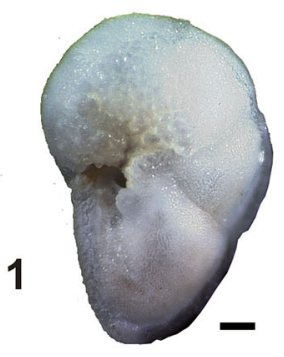

G. tumida tumida

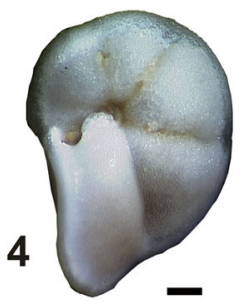

G. tumida flexuosa
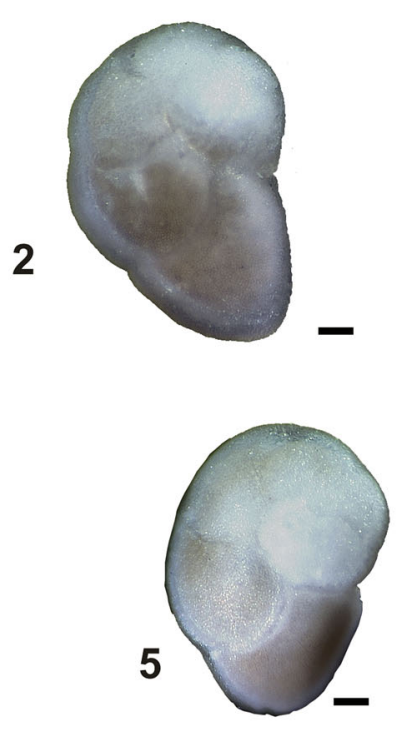
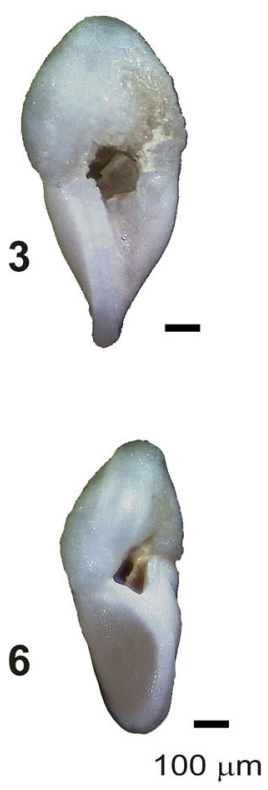

the region off southwest Africa with the result that fewer planktic organisms were imported from the Indian Ocean (Berger et al. 1989). In reverse one may argue that a declining MOM, such as the phase between 1.9 and 2.1 Ma, could have triggered an episode of stronger influence of the Agulhas Current and hence resulting in a short phase of warm water injection from the Indian Ocean carrying tropical planktic faunas with $G$. menardii into the South Atlantic (Figs. 18, 19, 20).

The size range of $G$. menardii after $2.3-1.95 \mathrm{Ma}$ (Site 925B) and after 2.58-1.7 Ma (Site 502) is distinctly broader than ever before (see Fig. 19), even during the time of the Pliocene Climatic Optimum between 3.25 and 3.05 Ma (Mudelsee and Raymo 2005). These observations combined with the above arguments support a seeding and dispersal event of large menardiforms between 2.3 and 1.95 Ma at Hole 925B (this study) and between 2.58 and 1.7 Ma at DSDP Site 502 (Knappertsbusch 2007), rather than being explained by punctuated adaptive size increase to climatically relaxed conditions.

In their deglacial proliferation hypothesis Sexton and Norris (2011) point to ocean ventilation as a plausible mechanistic explanation for the long and well-known correlation of $G$. menardii with Pleistocene glacial-interglacial cycles. However, this suggestion does not provide any compulsory explanation for the massive post-Pliocene size expansion observed in our case. In contrast, by assuming an undisturbed gradual and diffusive size evolution of $G$. menardii occurring in Indian Ocean or Pacific isolation over long enough time (as seen at DSDP Site 503) the Agulhas dispersal hypothesis provides a more solid ground for the interpretation of the data presented here.
The sudden size increase of post-Pliocene Atlantic $G$. menardii mimics punctuated evolution. But in fact it can be explained by a major seeding and passive dispersal episode from the Indian Ocean or the Pacific, as it was already postulated by Berger and Vincent (1986) and Berger and Wefer (1996), with further spread all along the South Equatorial- and North Brazil Currents and into the Caribbean Sea. The observed Atlantic-Pacific menardiform size dichotomy may be taken as evidence in favor of the Agulhas dispersal hypothesis.

Whether or not such gradual size increase of menardiforms as it was observed at DSDP Site 503 is widespread in the Indian Ocean or the Pacific needs to be tested with similar morphometric studies in the western Pacific Ocean, for example, and would help solving these interesting questions.

\section{Conclusions}

The past 8 million years of menardiform globorotalid history exhibits a considerable size increase, which is assumed the combined result of gradual background evolution of test size, lineage splitting, and long distance passive dispersal. In the eastern tropical Pacific Ocean a gradual and undisturbed pattern is seen. In the tropical Atlantic and Caribbean $G$. menardii diffusively expanded in test size to form the normally perforated G. menardii-limbata-multicamerata plexus with pan-tropical biogeography. The development of the G. menardii-G. limbata-G. multicamerata lineage occurred in two phases and can be well recognized at ODP Hole 925B. The onset of NHG strongly 
reduced size and abundance of $G$. menardii at the Atlantic ODP Site 925 and the Caribbean DSDP Site 502. During buildup of the Late Pliocene NHG and thereafter, $G$. menardii became repeatedly depleted to absent in the tropical Atlantic. Replenishment of large, tropical IndoPacific menardiforms into the Atlantic during a brief period of intensified Agulhas leakage around South Africa is interpreted to be the cause for the massive and sudden test size expansion of $G$. menardii in the two Atlantic-Caribbean cores after $1.95 \mathrm{Ma}$. These immigrants are hypothesized to have evolved to extra-large tests in pantropical Indian Ocean or Pacific isolation.

The divergent and "pseudo-allopatric" pattern of $G$. menardii size evolution between the Eastern Equatorial Pacific and the two tropical Atlantic-Caribbean sites is the result of four different evolutionary processes. First, the Pliocene phyletic evolution and extinction from ancestral small G. menardii to finely perforated menardiforms that are endemic to the Atlantic-Caribbean. Second, the evolution to the pan-tropical G. limbata $-G$. multicamerata clade during the Pliocene. Third, the continuous and gradual size increase of $G$. menardii in the Indian OceanPacific realm through the Quaternary. And fourth, the sudden post-NHG invasion (from $1.95 \mathrm{Ma}$ onwards) of populations of large-sized G. menardii from the Indian Ocean or Pacific into the tropical Atlantic via the Agulhas Current. In this model, slow, gradual, and unidirectional size increase is thus the conservative long-term mode of "background evolution", as long as environmental conditions remain stable. Environmental change and differentiation of habitats, as for example through regionally stronger stratification of the upper water column, produced vicariant divergence as seen with the extinct endemism of finely performed menardiforms in the tropical Atlantic.

In conclusion, this study could for the first time differentiate between longterm evolution and immigration events of G. menardii. The earlier model of the prominent, sudden and almost simultaneous size increase of $G$. menardii after 1.95 Ma in the tropical Atlantic-Caribbean due to adaptations to a changing upper water column structure during the emergence of the Isthmus of Panama must therefore be revised in favor of the alternative explanation of post-NHG immigration of populations of large G. menardii out of the Indian Ocean or the Pacific into the Atlantic.

In general, the Agulhas immigration hypothesis is compatible with notions of Banner (1982) and Chapman (2000) of iterative trends in Globigerinacea superimposed on non-iterative, unidirectional evolutionary changes. The cause of the iterative pattern parallels repeated environmental perturbations marked with immigration events, while the non-iterative background development reflects a mode of more undisturbed and continuous evolution in permanently stable environments.
Acknowledgments This study was part of the (project Evolutionary prospection in Neogene planktonic foraminifera, from 2009 to 2013, and was financed by the Swiss National Science Foundation (SNF grant Nos. 200021-121599 and 200020_137486/1). The realization of this project would not have been possible without the continuous and generous support over the years from the Natural History Museum Basel, its staff and colleagues, and of the City of Basel. Thorsten Bickert provided important information for numerical age determinations of the samples. The group around Jean Eisenecker and his students from the University of Applied Sciences (FHNW Brugg) were involved in improving the AMOR imaging system and software. The investigated sediment samples were generously provided by the Integrated Ocean Drilling Program, Request \#21438A, \#21438B, and \#21438D. The kind help of Stefanie Schumacher (AWI) for placing the data on Pangaea and the critical reading of the manuscript and the comments to improve English and grammar by Mark Leckie, Jörg Bollmann, Daniel Marty, Susanne Feist-Burkhardt and two anonymous reviewers are greatly acknowledged.

Open Access This article is distributed under the terms of the Creative Commons Attribution 4.0 International License (http://crea tivecommons.org/licenses/by/4.0/), which permits unrestricted use, distribution, and reproduction in any medium, provided you give appropriate credit to the original author(s) and the source, provide a link to the Creative Commons license, and indicate if changes were made.

\section{References}

André, A., Weiner, A., Quillévéré, F., Aurahs, R., Morard, R. Douady, C. J., et al. (2013). The cryptic and the apparent reversed: lack of genetic differentiation within the morphologically diverse plexus of the planktonic foraminifer Globigerinoides sacculifer. Paleobiology, 39(1), 21-39.

Aze, T. L. (2011). Cope's rule and macroevolution of Cenozoic macroperforate planktonic foraminifera. Ph.D. thesis, Cardiff University, p 598. http://orca.cf.ac.uk/id/eprint/22350

Aze, T., Ezartd, T. H., Purvis, A., Coxall, H. K., Stewart, D. R. M., Wade, B. S., \& Pearson, P. N. (2011). A phylogeny of Cenozoic macroperforate planktonic foraminifera from fossil data. Biological Reviews, 86, 900-927. doi:10.1111/j.1469-185X.2011. 00178x.

Bacon, C. D., Silvestro, D., Jaramillo, C., Smith, B. T., Chakrabarty, P., \& Antonelli, A. (2015). Biological evidence supports an early and complex emergence of the Isthmus of Panama. Proceedings of the National Academy of Science (PNAS), 112(19), 6110-6115.

Bandy, O. L. (1972). Origin and development of Globorotalia (Turborotalia) pachyderma (Ehrenberg). Micropaleontology, 18(3), 294-318.

Bandy, O. L. (1975). Messinian evaporate deposition and the Miocene/Pliocene boundary, Pasquasia-Capodarso Sections, Sicily. In T. Saito \& L. H. Burckle (Eds.), Late neogene epoch boundaries (pp. 49-63). New York: American Museum of Natural History, Micropaleontology Press.

Banner, F. T. (1982). A classification and introduction to the lobigerinacea. In F. T. Banner \& A. R. Lord (Eds.), Aspects of micropalaeontology (pp. 145-239). London: George Allen and Unwin.

Banner, F. T., \& Blow, W. H. (1965). Two new taxa of the Globorotaliinae (Globigerinacea, Foraminifera) assisting determination of the late Miocene/middle Miocene boundary. Nature, 207, 1351-1354. 
Bé, A. W. H. (1977). An ecological, zoogeographic and taxonomic review of recent planktonic foraminifera, Chapter 1. In A. T. S. Ramsay (Ed.), Oceanic micropalaeontology (Vol. 1, pp. 1-100). New York: Academic Press.

Bé, A. W. H., Damuth, J. E., Lott, L., \& Free, R. (1976). Late quaternary climatic record in western equatorial Atlantic sediment. In R. M. Cline \& J. D. Hays (Eds.), Investigation of late quaternary paleoceanography and paleoclimatology. Geological Society of America Memoir 145 (pp. 165-200). Boulder, Colorado: The Geological Society of America.

Bé, A. W. H., McIntyre, A., \& Breger, D. L. (1966). Shell microstructure of a planktonic foraminifer, Globorotalia menardii (D’Orbigny). Eclogae Geologicae Helvetiae, 59(2), 885-896.

Bé, A. W. H., \& Tolderlund, D. S. (1971). Distribution and ecology of living planktonic foraminifera in surface waters of the Atlantic and Indian Oceans. In B. M. Funnell \& W. R. Riedel (Eds.), The micropaleontology of the oceans (pp. 105-149). London: Cambridge University Press.

Beal, L. M., De Ruijter, W. P. M., Biastoch, A., Zahn, R., and the SCOR/WCRP/IAPSO Working Group 136. (2011). On the role of the Agulhas system in ocean circulation and climate. Nature, 472, 429-436.

Berger, W. H. (2013). On the beginnings of palaeoceanography: Foraminifera, pioneers and the Albatross expedition. In A. J. Bowden, F. J. Gregory, \& A. S. Henderson (Eds.), Landmarks in foraminiferal micropalaeontology: history and development (pp. 159-179). London: The Micropalaeontological Society, Special Publications, Geological Society of London.

Berger, W. H., \& Vincent, E. (1986). Sporadic shutdown of North Atlantic deep-water production during the Glacial-Holocene transition? Nature, 324(6092), 53-55.

Berger, W. H., \& Wefer, G. (1996). Expeditions into the past: palaeoceanographic studies in the South Atlantic. In G. Wefer, W. H. Berger, G. Siedler, \& D. J. Webb (Eds.), The South Atlantic: present and past circulation (pp. 363-410). Berlin: Springer.

Berger, W. H., Wefer, G., Richter, C., Lange, C. B., Giraudeau, J., Hermelin, O., \& Party, Shipboard Scientific. (1998). The Angola-Benguela upwelling system: Paleoceanographic synthesis of shipboard results from Leg 175. In G. Wefer, W. H. Berger, C. Richter, et al. (Eds.), Proceedings of the ocean drilling program, initial reports (Vol. 175, pp. 505-531). College Station: Ocean Drilling Program.

Berggren, W. A., Kent, D. V., Swisher, C. C., \& Aubry, M. P. (1995). A revised Cenozoic geochronology and chronostratigraphy. In W. A. Berggren, D. V. Kent, M. P. Aubry, \& J. Hardenbol (Eds.), Geochronology, time-scales, and global stratigraphic correlation (pp. 129-212). Tulsa: Society of Economic Paleontologists and Mineralogists. Special Publication No. 54.

Berggren, W. A., \& Lohmann, G. P. (1984). Species formation through punctuated gradualism in planktonic foraminifera. Science, 225, 317-319.

Bhonsale, S., \& Saraswat, R. (2012). Abundance and size variation of Globorotalia menardii in the northeastern Indian Ocean during the late quaternary. Journal of the Geological Society of India, $80,771-782$.

Bickert, T., Curry, W. B., \& Wefer, G. (1997). Late Pliocene to Holocene (2.6-0 Ma) western equatorial Atlantic deep-water circulation: Inferences from benthic stable isotopes. In N. J. Shackleton, W. B. Curry, C. Richter, \& T. J. Bralower (Eds.), Proceedings of the Ocean Drilling Program, scientific results (Vol. 154, pp. 239-253). College Station: Ocean Drilling Program.

Blow, W. H. (1969). Late middle eocene to recent planktonic foraminiferal biostratigraphy. In P. Brönnimann \& H. H. Renz (Eds.), Proceedings of the first international conference on planktonic microfossils, Geneva 1967 (Vol. 1, pp. 199-422). Leiden: EJ Brill.
Blow, W. H. (1979). The Cainozoic Globigerinida. A study of the morphology, taxonomy, evolutionary relationships and the stratigraphical distribution of some globigerinida (mainly Globigerinacea). Text, part II, section 2 (pp. 753-1413). Leiden: E.J. Brill.

Bolli, H. M. (1970). The foraminifera of sites 23-31, Leg 4. Initial reports of the deep sea drilling project (Vol. IV, pp. 577-643). Washington: US Government Printing Office.

Bolli, H. M. (1986). Evolutionary trends in planktic foraminifera from early Cretaceous to recent, with special emphasis on selected tertiary lineages. Bulletin du Centre de Recherche et de l'Exploration-Production Elf-Aquitaine (BCREDP), 10, 565-577.

Bolli, H. M., \& Saunders, J. B. (1985). Oligocene to Holocene low latitude planktic foraminifera. In H. M. Bolli, J. B. Saunders, \& K. Perch-Nielsen (Eds.), Plankton stratigraphy (pp. 155-262). Cambridge: Cambridge University Press.

Bollmann, J. (1997). Morphology and biogeography of Gephyrocapsa coccoliths in Holocene sediments. Marine Micropaleontology, 29, 319-350.

Braconnot, P., Harrison, S. P., Kageyama, M., Bartlein, P. J., MassonDelmotte, V., Abe-Ouchi, A., et al. (2012). Evaluation of climate models using palaeoclimatic data. Review. Nature Climate Change, 2, 417-424. doi:10.1038/nclimate1456.

Brigham-Grette, J., Melles, M., Minyuk, P., Andreev, A., Tarasov, P., DeConto, R., et al. (2013). Pliocene warmth, polar amplification, and stepped Pleistocene cooling recorded in NE arctic Russia. Science, 340, 1421-1427.

Broecker, W., \& Pena, L. D. (2014). Delayed Holocene reappearance of G. menardii. Paleoceanography, 29, 291-295.

Brown, K. R. (2007). Biogeographic and morphological variation in late Pleistocene to Holocene globorotalid foraminifera. Ph.D. Dissertation, University of Basel, p. 128

Caley, T., Giraudeaux, J., Malaizé, B., Rossignol, L., \& Pierre, C. (2012). Agulhas leakage as a key process in the modes of quaternary climate changes. PNAS, 109(18), 6835-6839.

Chaisson, W. P. (2003). Vicarious living: Pliocene menardellids between an isthmus and an ice sheet. Geology, 31(12), $1085-1088$.

Chaisson, W. P., \& Pearson, P. N. (1997). Planktonic foraminifer biostratigraphy at site 925: Middle Miocene-Pleistocene. In N. J. Shackleton, W. B. Curry, C. Richter, \& T. J. Bralower (Eds.), Proceedings of the Ocean Drilling Program, scientific results (Vol. 154, pp. 3-31). College Station: Ocean Drilling Program.

Chaisson, W. P., \& Ravelo, A. C. (1997). Changes in upper watercolumn structure at Site 925, late Miocene-Pleistocene: Planktonic foraminifer assemblage and isotopic evidence. In $\mathrm{N}$. J. Shackleton, W. B. Curry, C. Richter, \& T. J. Bralower (Eds.), Proceedings of the Ocean Drilling Program, scientific results (Vol. 154, pp. 255-268). College Station: Ocean Drilling Program.

Chandler, M., Dowsett, H., \& Haywood, A. (2008). The PRISM model/data cooperative: mid-Pliocene data model comparisons. Pages News, 16(2), 24-25.

Chapman, M. R. (2000). The response of planktonic foraminifera to the Late Pliocene intensification of Northern Hemisphere glaciation. In S. J. Culver \& P. F. Raeson (Eds.), Biotic response to global change. The last 145 million years (pp. 79-96). Cambridge: Cambridge University Press.

Chapman, M. R., Funnell, B. M., \& Weaver, P. P. E. (1998). Isolation, extinction and migration within Late Pliocene populations of planktonic foraminiferal lineage Globorotalia (Globoconella) in the North Atlantic. Marine Micropaleontology, 33, 203-222.

Cifelli, R. (1969). Radiation of Cenozoic planktonic foraminifera. Systematic Zoology, 18, 154-168.

Cifelli, R., \& Scott, G. (1986). Stratigraphic record of the Neogene globorotalid radiation (planktonic foraminifera). Smithsonian 
contributions to paleobiology (Vol. 58, pp. 1-101). Washington, DC: Smithsonian Institution Press.

Coates, A. G., Jackson, J. B. C., Collins, L. S., Cronin, T. M., Dowsett, H. J., Bybell, L. M., et al. (1992). Closure of the Isthmus of Panama: The near-shore marine record of CostaRica and western Panama. Geological Society of America Bulletin, 104, 814-828.

Coyne, J. A., \& Orr, H. A. (1989). The evolutionary genetics of speciation. Philosophical Transactions of the Royal Society of London. Series B, 353, 287-305.

Cronin, T. M., \& Dowsett, H. J. (1996). Biotic and oceanographic response to the Pliocene closing of the Central American isthmus. In J. B. C. Jackson, A. F. Budd, \& A. G. Coates (Eds.), Evolution and environment in tropical America (pp. 76-104). Chicago: University of Chicago Press.

Curry, W. B., Shackleton, N. J., Richter, C., et al. (1995). Site 925. In N. J. Shackleton, W. B. Curry, C. Richter, \& T. J. Bralower (Eds.), Proceedings of the Ocean Drilling Program, scientific results (Vol. 154, pp. 55-152). College Station: Ocean Drilling Program.

Cushman, J. A. (1927). An outline of a re-classification of the foraminifera. Contributions from the Cushman Laboratory of Foraminiferal Research, 3(1), 1-107.

Da Costa Portilho-Ramos, R., Fernandes Barbosa, C., \& Rios-Netto, A. M. (2014). Planktonic foraminiferal variations in the southwestern Atlantic since the last glacial-interglacial cycle. Palaios, $29,38-44$

Darling, K., Kucera, M., Pudsey, C. J., \& Wade, C. M. (2004). Molecular evidence links cryptic diversification in planktonic protists to quaternary dynamics. PNAS, 101(20), 7657-7662.

Darling, K. F., Wade, C. M., Kroon, D., \& Brown, A. J. L. (1997). Planktic foraminiferal molecular evolution and their phylogenetic origins from benthic taxa. Marine Micropaleontology, 30, 251-266.

Darling, K. F., Wade, C. M., Kroon, D., \& Brown, A. J. L. (1999). The diversity and distribution of modern planktonic foraminiferal small subunit ribosomal RNA genotypes and their potential as tracers of present and past ocean circulations. Paleoceanography, 14(1), 3-12.

De Vargas, C., Renaud, S., Hilbrecht, H., \& Pawlowski, J. (2001). Pleistocene adaptive radiation in Globorotalia truncatulinoides: Genetic, morphologic, and environmental evidence. Paleobiology, 27(1), 104-125.

De Vargas, C., Zaninetti, L., Hilbrecht, H., \& Pawlowski, J. (1997). Phylogeny and rates of molecular evolution of planktonic foraminifera: SSU rDNA sequences compared to the fossil record. Journal of Molecular Evolution, 45, 285-294.

Dobzhansky, Th. (1970). Genetics of the evolutionary process. New York: Columbia University Press.

Dowsett, H. J. (2007). The PRISM palaeoclimate reconstruction and Pliocene sea-surface temperature. In M. Williams, A. M. Haywood, F. J. Gregory, \& D. N. Schmidt (Eds.), Deep-Time perspectives on climate change: Marrying the signal from computer models and biological proxies. The micropaleontological Society, special publications (pp. 459-480). London: The Geological Society.

Duque-Caro, H. (1990). Neogene stratigraphy, paleoceanography and paleobiogeography in northwest South America and the evolution of the Panama Seaway. Palaeogeography, Palaeoclimatology, Palaeoecology, 77, 203-234.

Einum, S., \& Fleming, I. A. (2004). Environmental upredictability and offspring size: Conservative versus diversified bet-hedging. Evolutionary Ecology Research, 6, 443-455.

Eldredge, N., \& Gould, N. (1972). Punctuated equilibria: An alternative to phyletic gradualism. In T. J. M. Schopf (Ed.),
Models in paleobiology (pp. 82-115). San Francisco: Freeman, Cooper.

Ericson, D. B., \& Wollin, G. (1956a). Micropaleontological and isotopic determinations of Pleistocene climates. Micropaleontology, 2, 257-270.

Ericson, D. B., \& Wollin, G. (1956b). Correlation of six cores from the equatorial Atlantic and the Caribbean. Deep-Sea Research, 8, 104-125.

Ericson, D. B., \& Wollin, G. (1968). Pleistocene climates and chronology in deep-sea sediments. Science, 162, 1227-1234.

Fairbanks, R. G., \& Wiebe, P. H. (1980). Foraminifera and chlorophyll maximum: Vertical distribution, seasonal succession, and paleoceanographic significance. Science, 209, 1524-1526.

Farrell, J. W., Murray, D. W., McKenna, V. S., \& Ravelo, A. C. (1995). Upper ocean temperature and nutrient contrasts inferred from Pleistocene planktonic foraminifera $\delta^{18} \mathrm{O}$ and $\delta^{13} \mathrm{C}$ in the Eastern Equatorial Pacific. In N. G. Pisias, L. A. Mayer, T. R. Janacek, A. Palmer-Julson, \& T. H. van Andel (Eds.), Proceedings of the ODP, scientific results, 138 (pp. 289-319). College Station: Ocean Drilling Program.

Fedorov, A. V., Brierley, C. M., Lawrence, K. T., Liu, Z., Dekens, P. S., \& Ravelo, A. C. (2013). Patterns and mechanisms of early Pliocene warmth. Nature, 496, 43-49.

Fleisher, R. L. (1974). Cenozoic planktonic foraminifera and biostratigraphy, Arabia Sea; Deep Sea Drilling Project, leg 23A. In R. B. Whitmarsh, O. E. Weser, D. A. Ross, et al. (Eds.), Initial reports of the Deep Sea Drilling Project (Vol. 23, pp. 101-1072). Washington: US Government Printing Office.

Flores, J.-A., Gersonde, R., \& Sierro, F. J. (1999). Pleistocene fluctuations in the Agulhas Current Retroflection based on the calcareous plankton record. Marine Micropaleontology, 37, $1-22$.

Fornasini, C. (1902). Sinossi metodica dei foraminiferi sin qui rinvenuti nella sabbia del Lido di Rimini. Academia de la scienze di Bologna, ser. 5, 10(1902-1904), 1-68.

Gardner, J. V., \& Hays, J. D. (1976). Responses of sea-surface temperature and circulation to global climatic change during the past 20,000 years in the Eastern Equatorial Atlantic Ocean. In R. M. Cline \& J. D. Hays (Eds.), Investigation of late quaternary paleoceanography and paleoclimatology. Geological Society of America Memoir 145 (pp. 221-246). Boulder: The Geological Society of America.

Gibbard, P., \& van Kolfschoten, T. (2004). The pleistocene and holocene epochs. In F. Gradstein, J. Ogg, \& A. Smith (Eds.), A geologic time scale 2004 (pp. 441-452). Cambridge: Cambridge University Press.

Giraudeau, J., Pierre, C., \& Herve, L. (2002). A late quaternary, highresolution record of planktonic foraminiferal species distribution in the southern Benguela region: Site 1087. In G. Wefer, W. H. Berger, C. Richter, et al. (Eds.), Proceedings of the Ocean Drilling Program, scientific reports (Vol. 175, pp. 1-26). College Station: Ocean Drilling Program.

Gordon, A. L. (1985). Indian-Atlantic transfer of thermocline water at the Agulhas Retroflection. Science, 227(4690), 1030-1033.

Hall, I. R., Hemming, S. R., LeVay, L. J. (2015). Expedition 361 scientific prospectus: South African climates (Agulhas LGM density profile). International Ocean Discovery Program, p. 51. doi:10.14379/iodp.sp.361.2015.

Haug, G. H., Tiedemann, R., Zahn, R., \& Ravelo, A. C. (2001). Role of Panama uplift on oceanic freshwater balance. Geology, 29, 207-210

Haywood, A. M., Hill, D. J., Dolan, A. M., Otto-Bliesner, B. L., Bragg, F., Chan, W.-L., et al. (2013). Large-scale features of Pliocene climate: Results from the Pliocene Model 
Intercomparison Project. Climate of the Past, 9, 191-209. doi:10. 5194/cp-9-191-2013.

Haywood, A. M., Valdes, P. J., Hill, D. J., \& Williams, M. (2007). The mid-Pliocene warm period: A test-bed for integrating data and models. In M. Williams, A. M. Haywood, F. J. Gregory, \& D. N. Schmidt (Eds.), Deep-time perspectives on climate change: Marrying the signal from computer models and biological proxies. The Micropaleontological Society, special publications (pp. 443-457). London: The Geological Society.

Healy-Williams, N., \& Williams, D. F. (1981). Fourier analysis of test shape of planktonic foraminifera. Nature, 289, 485-487.

Hill, D. J., Haywood, A. M., Lunt, D. J., Otto-Bliesner, B. L., Harrison, S. P., \& Braconnot, P. (2012). Paleoclimate modelling: An integrated component of climate change science. Pages News, 20(2), 103.

Hills, S. J. (1988). The analysis of microfossil shape: Experiments using planktonic foraminifera. Ph.D. dissertation (p. 227). University of San Diego: Scripps Institution of Oceanography.

Hohenegger, J. (2014). Species as the basic units in evolution and biodiversity: Recognition of species in the recent and geological past as exemplified by larger foraminifera. Gondwana Research, $25,707-728$.

Hone, D. W., \& Benton, M. J. (2005). The evolution of large size: How does Cope's rule work? Trends in Ecology and Evolution, 20(1), 4-6.

Hottinger, L. (1962). Documents micropaléontologiques sur le Maroc: Remarques générales et bibliographie analytique. Notes Serv. Géol. Maroc, t. 21, 156, 7-14.

Hottinger, L. (1963). Les alvéolines paléogènes, exemple d'un genre polyphylétique. In G. H. R. Koenigswald, J. D. Emeis, W. L. Buning, \& C. W. Wagner (Eds.), Evolutionary trends in foraminifera (pp. 298-314). Amsterdam: Elsevier Publishing Company.

Hottinger, L. (1982). Larger foraminifera, giant cells with a historical background. Naturwissenschaften, 69, 361-371.

Hottinger, L. (2000). Adaptations of the foraminiferal cell to life in shallow carbonate environments. Accademia Nazionale di Science, Lettere e Arti di Modena. Collana di Studi, vol. 21. Crisi biologiche, radiazioni adattivi e dinamica delle piattaforme carbonatiche. Convegno di fine progetto nazionale di ricerca COFIN 97. Modena, 13-14 giugno 2000, pp. 135-140.

Hottinger, L. (2001). Learning from the past? In D. Baltimore, R. Dulbecco, F. Jacob, \& R. Levi-Montalcini (Eds.), Frontiers of Life (Vol. 4, pp. 449-477)., The living world, part 2: Discovery and spoliation of the biosphere London: Academic Press.

Huber, B. T., Bijma, J., \& Darling, K. (1997). Cryptic speciation in the living planktonic foraminifer Globigerinella siphonifera (d'Orbigny). Paleobiology, 23(1), 33-62.

Ibaraki, M. (2002). Responses of planktonic foraminifera to the emergence of the Isthmus of Panama. Revista Mexicana de Ciencias Geologicas, 19(3), 152-160.

Ishitani, Y., Ujiié, Y., \& Takishita, K. (2014). Uncovering sibling species in radiolarian: Evidence for ecological partitioning in a marine planktonic protist. Molecular Phylogenetics and Evolution, 78, 215-222.

Jackson, J. B., \& O'Dea, A. (2013). Timing of the oceanographic and biological isolation of the Caribbean Sea from the Tropical Eastern Pacific Ocean. Bulletin of Marine Science, 89(4), 779-800

Jagadeeshan, S., \& O'Dea, A. (2012). Integrating fossils and molecules to study cupuladriid evolution in an emerging Isthmus. Evolutionary Ecology, 26(2), 337-355.

Jansen, E., Mayer, L. A., Backman, J., Lecie, R. M., \& Takayama, T. (1993). Evolution of Pliocene climate cyclicity at Hole 806B (5$2 \mathrm{Ma}$ ): oxygen isotope record. In W. H. Berger, L. W. Kroenke, L. A. Mayer, et al. (Eds.), Proceedings of the ODP, scientific results, 130 (pp. 349-362). College Station: Ocean Drilling Program.

Kaneps, A. G. (1979). Gulf stream: Velocity fluctuations during the late Cenozoic. Science, 204, 297-301.

Keigwin, L. D, Jr. (1978). Pliocene closing of the Isthmus of Panama, based on biostratigraphic evidence from nearby Pacific Ocean and Caribbean Sea cores. Geology, 6, 630-634.

Keigwin, L. D. (1982). Neogene planktonic foraminifers from DeepSea Drilling Project Sites 502 and 503. In W. L. Prell, J. V. Gardner, et al. (Eds.), Initial reports of the DSDP, 68 (pp. 269-288). Washington: US Government Printing Office.

Kennett, J. P., \& Srinivasan, S. (1983). Neogene planktonic foraminifera. A phylogenetic atlas. Stroudsburg: Hutchinson Ross Publishing Company.

Kingsolver, J. G., \& Pfennig, D. W. (2004). Individual-level fluctuation as a cause of Cope's rule of phyletic size increase. Evolution, 58(7), 1608-1612.

Klocker, A., Prange, M., \& Schulz, M. (2005). Testing the influence of the Central American Seaway on orbitally forced Northern Hemisphere glaciation. Geophysical Research Letters, 32((L03703)), 4.

Knappertsbusch, M. (1990). Geographic distribution of modern coccolithophorids in the Mediterranean Sea and morphological evolution of Calcidiscus leptoporus. Dissertation ETH Zürich, p. 141.

Knappertsbusch, M. (2000). Morphological evolution of the coccolithophorid Calcidiscus leptoporus from the Early Miocene to Recent. Journal of Paleontology, 74(3), 712-730.

Knappertsbusch, M., (2007). Morphological variability of Globorotalia menardii (planktonic foraminiferan) in two DSDP cores from the Caribbean Sea and the Eastern Equatorial Pacific. Carnets de Géologie/Notebooks on Geology, Article 2007/04 (CG2007_A04). Brest.

Knappertsbusch, M. (2011). Evolution im marinen plankton. Mitteilungen der Naturforschenden Gesellschaften beider Basel, 13, 3-14.

Knappertsbusch, M. (2015a). MorphCol 2004-2013. A collection of Fortran 77 programs for geometric morphometry. Technical report. Naturhistorisches Museum Basel, Augustinergasse 2, 4001-Basel, Switzerland. http://doi.pangaea.de/10.1594/PAN GAEA. 848773

Knappertsbusch, M. (2015b). Raw-data to morphometric investigations about the Neogene planktonic foraminifer Globorotalia menardii and related forms from ODP Hole 154-925B (Céara Rise, western tropical Atlantic). http://doi.pangaea.de/10.1594/ PANGAEA. 855898

Knappertsbusch, M., Binggeli, D., Herzig, A., Schmutz, L., Stapfer, S., Schneider, C., Eisenecker, J., and Widmer, L. (2009). AMOR-A new system for automated imaging of microfossils for morphometric analyses. Palaeontologia Electronica, 12(Issue 2; 2T): p. 20. http://palaeo-electronica.org/2009_2/165/index.html

Knappertsbusch, M., Brown, K.R. and Rüegg, H.R. (2006). Positioning and enhanced stereographic imaging of microfossils in reflected light. Palaeontologia Electronica, 9(Issue 2; 8A): p. 10, 30.1 MB. http://palaeo-electronica.org/2006_2/reflect/index. html

Knappertsbusch, M.W. and Mary, Y. (2012). Mining morphological evolution in microfossils using volume density diagrams. Palaeontologia Electronica, 15(Issue 3; 7T): p. 29. http:// palaeo-electronica.org/content/issue-3-2012-technical-articles/ 282-volume-density-diagrams

Kucera, M., \& Darling, K. F. (2002). Cryptic species of planktonic foraminifera: Their effect on palaeoceanographic reconstructions. Phil. Trans. R. Soc. London, A., 360, 695-718.

Kucera, M., \& Malmgren, B. A. (1996). Latitudinal variation in the planktic foraminifer Contusotruncana contusa in the terminal Cretaceous ocean. Marine Micropaleontology, 28, 31-52. 
Langer, M. R. (1999). Origin of foraminifera: Conflicting molecular and paleontological data ? Marine Micropaleontology, 38, 1-5.

LaRiviere, J. P., Ravelo, A Ch., Crimmins, A., Dekens, P. S., Ford, H. L., Lyle, M., \& Wara, M. W. (2012). Late Miocene decoupling of oceanic warmth and atmospheric carbon dioxide forcing. Nature, 486, 97-100.

Lawrence, K.T., Zhonghui, L., Herbert, T.D. (2006). Evolution of the Eastern Tropical Pacific Through Plio-Pleistocene Glaciation. Science, 312(5770), 79-83.

Lazarus, D. (1983). Speciation in pelagic Protista and its study in the planktonic microfossil record: A review. Paleobiology, 9(4), 327-340.

Lazarus, D. (1992). Age depth plot and age maker: Age modelling of stratigraphic sections on the Macintosh series of computers. Geobyte, 2(1992), 7-13.

Lazarus, D. B., Hilbrecht, H., Spencer-Cervato, C., \& Thierstein, H. (1995). Sympatric speciation and phyletic change in Globorotalia truncatulinoides (planktonic foraminifera). Paleobiology, $21,28-51$.

Leckie, R. M. (1989). An oceanographic model for the early evolutionary history of planktonic foraminifera. Palaeogeography, Palaeoclimatology, Palaeoecology, 73, 107-138.

Leigh, E. G., O'Dea, A., \& Vermeij, G. J. (2013). Historical biogeography of the Isthmus of Panama. Biological Reviews. doi:10.1111/brv.12048.

Lourens, L., Hilgen, F., Shackleton, N. J., Laskar, J., \& Wilson, D. (2004). The neogene period. In F. Gradstein, J. Ogg, \& A. Smith (Eds.), A geologic time scale 2004 (pp. 409-440). Cambridge: Cambridge University Press.

Lunt, D. J., Haywood, A. M., Schmidt, G. A., Salzmann, U., Valdes, P. J., \& Dowsett, H. J. (2010). Earth system sensitivity inferred from Pliocene modelling and data. Nature Geoscience, 3, 60-64.

Lutjeharms, J. R. E., \& Gordon, A. L. (1987). Shedding of an Agulhas ring observed at Sea. Nature, 325, 138-140.

Lutjeharms, J. R. E., \& Kortum, G. (2005). German research on the Agulhas current system between the World Wars; a lost scientific achievement. Historisch-Meereskundliches Jahrbuch (Vol. 11, pp. 73-80). Stralsund: Deutsches Meeresmuseum.

Lutz, B. P. (2011). Shifts in North Atlantic planktic foraminifer biogeography and subtropical gyre circulation during the MidPiacenzian warm period. Marine Micropaleontology, 80, 125-149.

Mallet, J. (2007). Species, concepts of. In S. Levin, et al. (Eds.), Encyclopedia of biodiversity (Vol. 5, pp. 427-440). Oxford: Elsevier.

Malmgren, B. A., Berggren, W. A., \& Lohmann, G. P. (1983). Evidence for punctual gradualism in the late Neogene Globorotalia tumida lineage of planktonic foraminifera. Paleobiology, 9(4), 377-389.

Malmgren, B. A., \& Kennett, J. P. (1983). Phyletic gradualism in the Globorotalia inflata lineage vindicated. Paleobiology, 9(4), 427-428.

Marino, G., \& Zahn, R. (2015). The Agulhas leakage: The missing link in the interhemispheric climate seesaw? Past Global Changes Magazine, 23(1), 22-23.

Marlow, J. R., Lange, C. B., Wefer, G., \& Rosell-Melé, A. (2000). Upwelling intensification as part of the Pliocene-Pleistocene climate transition. Science, 290(5500), 2288-2291.

Marshall, L. G. (1988). Land mammals and the great American interchange. American Scientist, 76, 380-388.

Marshall, L. G., Butler, R. F., Drake, R. E., Curtis, G. H., \& Tedford, R. H. (1979). Calibration of the great American interchange. A radioisotope chronology for late tertiary interchange of terrestrial faunas between the Americas. Science, 204, 272-279.

Marshall, L. G., Webb, S. D., Sepkoski, J. J, Jr, \& Raup, D. M. (1982). Mammalian evolution and the great American interchange. Science, 215(4538), 1351-1357.
Mary, Y. (2013). Morphologic, biogeographic and ontogenetic investigation of Mid-Pliocene menardellids (planktonic foraminifera). Ph.D. Dissertation. Phil. Nat. Fakultät, Universität Basel, p. 173. http://edoc.unibas.ch/diss/DissB_10611/

Mary, Y., \& Knappertsbusch, M. (2013). Morphological variability of menardiform globorotalids in the Atlantic Ocean during MidPliocene. Marine Micropaleontology, 101, 180-193. doi:10. 1016/j.marmicro.2012.12.001.

Mary, Y., \& Knappertsbusch, M. (2015). Worldwide morphological variability in Mid-Pliocene menardellid globorotalids. Marine Micropaleontology, 121, 1-15. doi:10.1016/j.marmicro.2015.09. 001.

McGowran, B. (2005). Biostratigraphy. Microfossils and geological time. New York: Cambridge University Press.

McIntyre, A. (1967). Coccoliths as paleoclimatic indicators of Pleistocene glaciation. Science, 158, 1314-1317.

McIntyre, A. and Cline, R. (1981). Seasonal reconstructions of the earth's surface at the last glacial maximum. The Geological Society of America, map and chart series, MC 36, Contribution no. 3153. Palisades, New York 10964: Lamont-Doherty Geological Observatory of Columbia University.

McKinney, M.L. (1990). Trends in body-size evolution. In McNamara, K.J. (Ed.), Evolutionary Trends, chapter 4 (pp. 75-118). Tuscon, Arizona: The University of Arizona Press

McShea, D. (1994). Mechanisms of large-scale evolutionary trends. Evolution, 48(6), 1747-1763.

Mikolajewicz, U., \& Crowley, T. J. (1997). Response of a coupled ocean/energy balance model to restricted flow through the central American isthmus. Paleoceanography, 12(3), 429-441.

Miller, K. G., Kominz, M. A., Browning, J. V., Wright, J. D., Mountain, G. S., Katz, M. E., et al. (2005). The Phanerozoic record of global sea-level change. Science, 310(5752), 1293-1298.

Mitteroecker, P., \& Huttegger, S. M. (2009). The concept of morphospaces in evolutionary and developmental biology: Mathematics and metaphors. Biological Theory, 4(1), 54-67.

Molnar, P. (2008). Closing of the Central American Seaway and the ice age: A critical review. Paleoceanography, 23, PA2201.

Mudelsee, M., \& Raymo, M. E. (2005). Slow dynamics of the Northern hemisphere glaciation. Paleoceanography, 20, 14. doi:10.1029/2005PA001153.

Nathan, R., \& Nathan, O. (2014). Unlikely yet pivotal long dispersals. Science, 344, 153-154.

Newman, M. E. J., \& Palmer, R. G. (2003). Modeling extinction (p. 109). New York: Oxford University Press.

Norris, R. D., Corfield, R. M., \& Cartlidge, J. (1996). What's gradualism ? Cryptic speciation in globorotalid foraminifera. Paleobiology, 22(3), 386-405.

O’Brien, C. L., Foster, G. L., Martinez-Boti, M. A., Abell, R., Rae, J. W. B., \& Pancost, R. D. (2014). High sea surface temperatures in tropical warm pools during the Pliocene. Nature Geoscience, 7, 606-611.

O’Dea, A., Hoyos, N., Rodriguez, F., De Garcia, B., \& Degracia, C. (2012). History of upwelling in the tropical eastern Pacific and the paleoceanography of the Isthmus of Panama. Palaeogeography, Palaeoclimatology, Palaeoecology. doi:10.1016/j.palaeo. 2012.06.007.

Pagani, M., Liu, Z., LaRiviere, J., \& Ravelo, A. C. (2010). High earthsystem climate sensitivity determined from Pliocene carbon dioxide concentrations. Nature Geoscience, 3, 27-30.

Parker, W. C., Feldman, A., \& Arnold, A. J. (1999). Paleobiogeographic patterns in the morphologic diversification of the Neogene planktonic foraminifera. Palaeogeography, Palaeoclimatology, Palaeoecology, 152, 1-14.

Pearson, P. N., \& Ezard, T. H. G. (2014). Evolution and speciation in the Eocene planktonic foraminifer Turborotalia. Paleobiology, 40(1), 130-143. 
Peeters, F. J. C., Acheson, R., Brummer, G.-J. A., Ruijter, W. P. M., Schneider, R. A., Ganssen, G. M., et al. (2004). Vigorous exchange between the Indian and Atlantic Oceans at the end of the past five glacial periods. Nature, 430, 661-665.

Pfuhl, H. A., \& Shackleton, N. J. (2004). Changes in coiling direction, habitat depth and abundance in two menardellid species. Marine Micropaleontology, 50, 3-20.

Prell, W. L., \& Hays, J. D. (1976). Late Pleistocene faunal and temperature patterns of the Colombia Basin, Caribbean Sea. In R. M. Cline \& J. D. Hays (Eds.), Investigation of late quaternary paleoceanography and paleoclimatology. Geological Society of America Memoir 145 (pp. 201-220). Boulder: The Geological Society of America.

Rau, A., Rogers, J., \& Chen, M.-T. (2006). Late quaternary palaeoceanographic record in giant piston cores off South Africa, possibly including evidence of neotectonism. Quaternary International, 148, 65-77.

Rau, A. J., Rogers, J., Lutjeharms, J. R. E., Giraudeau, J., Lee-Thorp, J. A., Chen, M.-T., \& Waelbroeck, C. (2002). A 450-kyrs record of hydrological conditions on the western Agulhas Bank Slope, south of Africa. Marine Geology, 180, 183-201.

Ravelo, A. C., Dekens, P. S., \& McCarthy, M. (2006). Evidence for El Nino-like conditions during the Pliocene. GSA Today, 16(3), 4-11. doi:10.1130/1052-5173(2006)016<4:EFENLC >2.0.CO;2.

Ravelo, A. C., \& Fairbanks, R. G. (1992). Oxygen isotopic composition of multiple species of planktonic foraminifera: Recorders of the modern photic zone temperature gradient. Paleoceanography, 7, 815-831.

Saito, T. (1976). Geologic significance of coiling direction in the planktonic foraminifera Pulleniatina. Geology, 4, 305-309.

Schaub, H. (1963). Über einige Entwicklungsreihen von Nummulites und Assilina und ihre stratigraphische Bedeutung. In G. H. R. Koenigswald, J. D. Emeis, W. L. Buning, \& C. W. Wagner (Eds.), Evolutionary trends in foraminifera (pp. 282-297). Amsterdam: Elsevier Publishing Company.

Schmid, K. (1934). Biometrische Untersuchungen an Foraminiferen (Globorotalia menardii (d'Orb.) - Globorotalia tumida (Brady) und Truncatulina margaritifera Brady—Truncatulina margaritifera granulosa Fischer) aus dem Pliozän von Ceram (Niederl.Indien). Eclogae Geologicae Helvetiae, 27(1), 45-134.

Schmidt, D.N. (2002). Size variability in planktonic foraminifers. Ph.D. Dissertation No. 14578 (p. 121). Zürich: ETH Zürich.

Schmidt, D. N., Thierstein, H. R., Bollmann, J., \& Schiebel, R. (2004). Abiotic forcing of plankton evolution in the Cenozoic. Science, 303, 207-2010.

Schmidt, D.N., Lazarus, D., Young, J.R., and Kucera, M. (2006). Biogeography and evolution of body size in marine plankton. Earth-Science Reviews, 78(3-4), 239-266.

Schneider, T., Bischoff, T., \& Haug, G. H. (2014). Migrations and dynamics of the intertropical convergence zone. Nature, 513, 45-53.

Schott, W. (1935). Die Foraminiferen aus dem äquatorialen Teil des Atlantischen Ozeans. Wissenschaftliche Ergebnisse, Deutsche Atlantische Expedition Meteor, 1925-1927(3), 43-134.

Schubert, M. F., Chhajed, S., Kim, J. K., Schubert, E. F., \& Cho, J. (2007). Linearly polarized emission from GaInN light-emitting diodes with polarization-enhancing reflector. Optics Express, 15(18), 11213-11218.

Schweitzer, P. N., \& Lohmann, G. P. (1991). Ontogeny and habitat of modern menardiform planktonic foraminifera. Journal of Foraminiferal Research, 21(4), 332-346.

Scott, G. H. (2011). Holotypes in the taxonomy of planktonic foraminiferal morphospecies. Marine Micropaleontology, 78, 96-100.

Scussolini, P., van Sebille, E., Durgadoo, J.V. (2013). Paleo Agulhas rings enter the subtropical gyre during the penultimate deglaciation. Climate of the Past, 9, 2631-2639. www.climpast.net/9/2631/2013/

Sexton, P. F., \& Norris, R. D. (2008). Dispersal and biogeography of marine plankton: Long-distance dispersal of the foraminifer Truncorotalia truncatulinoides. Geology, 36(11), 899-902.

Sexton, P. F., \& Norris, R. D. (2011). High latitude regulation of low latitude thermocline ventilation and planktic foraminifer populations across glacial-interglacial cycles. Earth and Planetary Science Letters, 311, 69-81.

Shackleton, N. J., \& Opdyke, N. D. (1977). Oxygen isotope and palaeomagnetic evidence for early Northern Hemisphere glaciation. Nature, 270, 216-219.

Shoval, O., Sheftel, H., Shinar, G., Hart, Y., Ramote, O., Mayo, A., et al. (2012). Evolutionary trade-offs, pareto optimality, and the geometry of phenotype space. Science, 336, 1157-1160.

Spencer-Cervato, C., \& Thierstein, H. R. (1997). First appearance of Globorotalia truncatulinoides: Cladogenesis and immigration. Marine Micropaleontology, 30, 267-291.

Srinivasan, M. S., Kennett, J. P., \& Bé, A. W. H. (1974). Globorotalia menardii neoflexuosa new subspecies from the northern Indian Ocean. Dee-Sea Research, 21, 321-324.

Stainforth, R.M., Lamb, J.L., Luterbacher, H., Beard, H.J., and Jeffords, R.M. (1975). Cenozoic planktonic foraminiferal zonation and characteristics of index forms. The University of Kansas Paleontological Contributions, Article 62, 1-425.

Stanley, S.M. (1973). An Explanation for Cope's Rule. Evolution, 27(1), 1-26.

Steph, S., Tiedemann, R., Groenveld, J., Sturm, A., \& Nürnberg, D. (2006). Pliocene changes in tropical east Pacific upper ocean stratification. Response to tropical gateways? In R. Tiedemann, A. C. Mix, C. Richter, \& W. F. Ruddiman (Eds.), Proceedings of the Ocean Drilling Program, scientific results (Vol. 202, p. 1). College Station: Ocean Drilling Program.

Steph, S., Tiedemann, R., Prange, M., Groenveld, J., Schulz, M., Timmermann, A., et al. (2010). Early Pliocene increase in thermocline overturning: A precondition for the development of the modern equatorial Pacific cold tongue. Paleoceanography, 25, 17. doi:10.1029/2008PA001645.

Stewart, D.R.M. (2003). Evolution of Neogene globorotaliid foraminifera and Miocene climate change. Ph.D. dissertation, University of Bristol, Faculty of Science, EThOS Persistent ID: uk.bl.ethos.288306, p. 331.

Stone, R. (2013). Battle for the Americas. Science, 341, 230-233.

Strotz, L. C., \& Allen, P. (2013). Assessing the role of cladogenesis in macroevolution by integrating fossil and molecular evidence. PNAS, 110(8), 2904-2909.

Tiedemann, R., Sarnthein, M., \& Shackleton, N. J. (1994). Astronomic timescale for the Pliocene $\delta^{18} \mathrm{O}$ and dust flux records of Ocean Drilling Program Site 659. Paleoceanography, 9, 619-638.

Vella, P. (1963). Biostratigraphic units. New Zealand Journal of Geology and Geophysics, 7(3), 615-625.

Villar, E., Farrant, G. K., Follows, M., Garczarek, L., Speich, S., Audic, S., et al. (2015). Environmental characteristics of Agulhas rings affect interocean plankton transport. Science, 348(6237), 1261447-1-10. doi:10.1126/science.1261447.

Von der Heidt, A. S., \& Dijkstra, H. A. (2011). El Nino in the Pliocene. Nature Geoscience, 4(8), 502-503.

Von der Heydt, A., \& Dijkstra, H. (2005). Flow reorganization in the Panama Seaway: A cause for the demise of Miocene corals ? Geophysical Research Letters, 32, 4.

Wade, B. S., \& Olsson, R. K. (2009). Investigation of pre-extinction dwarfing in Cenozoic planktonic foraminifera. Palaeogeography, Palaeoclimatology, Palaeoecology, 284, 39-46.

Wara, M.W., Ravelo, A.C., \& Delaney, M.L. (2005). Permanent El Niño-Like Conditions During the Pliocene Warm Period. Science, 309(5735), pp. 758-761. doi:10.1126/science.1112596 
Weiner, A. K. M., Weinkauf, M. F. G., Kurasawa, A., Darling, K. F., \& Kucera, M. (2015). Genetic and morphometric evidence for parallel evolution of the Globigerinella calida morphotype. Marine Micropaleontology, 114, 19-35.

Weiner, A.K.M., Weinkauf, M.F.G., Kurasawa, A., Darling, K.F., Kucera, M., and Grimm, G.W. (2014). Phylogeography of the tropical planktonic foraminifera lineage Globigerinella reveals isolation inconsistent with passive dispersal by ocean currents. PLoS One, 9(3), 1-12, e92148.

Woodard, S. C., Rosenthal, Y., Miller, K. G., Wright, J. D., Chiu, B. K., \& Lawrence, K. T. (2014). Antarctic role in northern hemishere glaciation. Science, 346(6211), 847-851.

Woodburne, M. O. (2010). The great American biotic interchange: Dispersals, tectonics, climate, sea level and holding pens. Journal of Mammal Evolution, 17, 245-264. doi:10.1007/ s10914-010-9144-8.
Young, J. R., Liu, H., Probert, J., Aris-Brosou, S., \& de Vargas, C. (2014). Morphospecies versus phylospecies concepts for evaluating phytoplankton diversity: The case of the coccolithophores. Cryptogamiie, Algologie, 35(4), 353-377.

Zachos, J., Pagani, M., Sloan, L., Thomas, E., \& Billups, K. (2001). Trends, rhythms, and aberrations in global climate $65 \mathrm{Ma}$ to present. Science, 292, 686-693.

Zahn, R., Hall, I., Schneider, R., Barker, S., Compton, J., Dupont, L., Flores, J.-A., Franzese, A., Goldstein, S., Hemming, S., Knorr, G., Marino, G., Mazaud, A., Peeters, F., Preu, B., Reichart, G.-J., Spiess, V., Uenzelmann-Neben, G., Weldeab, S., Ziegler, M. (2012). Southern African climates, Agulhas warm water transports and retroflection, and interocean exchanges-SAFARI. IODP Proposal 702-Full2, pp. 1-33. http://iodp.tamu.edu/ scienceops/precruise/safari/summary.html 